Universidade de São Paulo

Departamento de Física $\theta$ Ciências dos Materiais

\title{
Construção de um Difratômetro
}

$\theta \theta$

\author{
José Dalton Cruz Pessoa
}

Dissertação apresentada ao Instituto de Física e Química de São Carlos-USP para obtenção do título de Mestre em Ciências (Física Aplicada).

Orientador: Prof. Dr. Antônio Ricardo Dröher Rodrigues

ok.

São Carlos - S.P.

1992

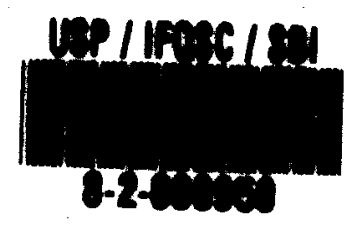




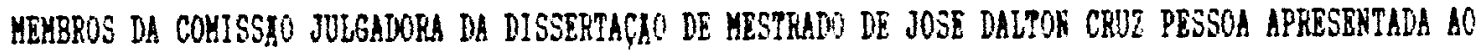

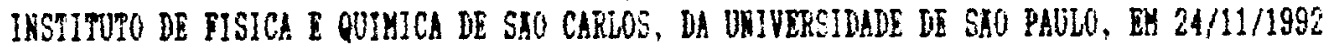

COMISSAO JULGADORA:

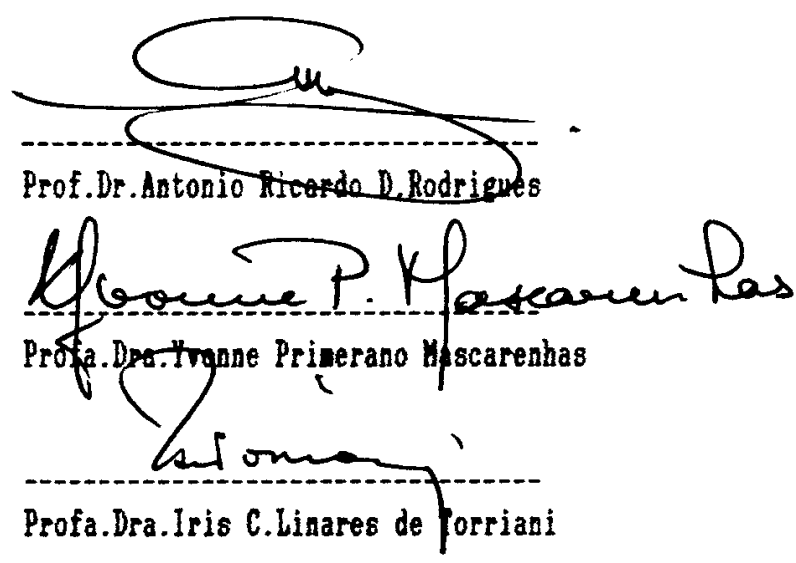




\section{Agradecimentos}

Este trabalho não teria sido realizado sem a presença da Profa. Yvonne Primerano Mascarenhas e do Prof. Antônio Ricardo Dröher Rodrigues. Guardo por eles um profundo respeito e gratidão pela postura que adotaram em relação a mim. Certamente aprendi muito com eles... além disto eles me fizeram ver que de certo modo vale a pena fazer ciência.

Gostaria de agradecer à chefia do NPDIA, em particular ao Dr. Ladislau Martins Neto, pelo apoio que permitiu a conclusão deste trabalho.

Aos que me ajudaram, meus sinceros agradecimentos: ao pessoal do IFQSC, do NPDIA e do LNLS.

Este projeto recebeu o apoio financeiro do PADCT/FINEP. 


\section{Tabela de Conteúdo}

Agradecimentos

Tabela de Conteúdo

Llsta de Figuras

Llsta de Tabelas

Abstract

Resumo

Introdução

Capftulo I

Espalhamento Elástlco de Ralos x

I.1 Policristais

I.1.1 Estrutura

I.1.2 Conteúdo Informacional do Difratograma

1.2 Soluç̄̄es

1.2.1 Estrutura

I.2.2 Conteúdo Informacional do Difratograma

Capítulo II

Optica dos Difratómetros de Raios X

II.1 Geometrias mais utilizadas em difratometria

II.2 Monocromadores

Capítulo III

O Difratómetro Proposto

III.1 Descrição Mecânica

III.2 Descrição Óptica

III.3 Alinhamento

Capítulo IV

o Acionamento do Difratômetro

IV.1 Movimentação do Difratômetro, Controle e Processamento dos Sinais

Capitulo V

IV.2 Programas de Comunicação

Testes de Caracterização Realizados com o Difratômetro

V.1 Caracterização

V.2 Observações

V.3 Difratogramas

Capitulo VI

Discussão e Conclusão

VI.1 Discussão

VI.2 Conclusão

Referênclas Bibliográficas

Apêndice I Listagem dos Programas

Apêndice || Desenho do Difratômetro

Apéndice III Fotos do Difratômetro 


\section{Lista de Figuras}

Figura 1.1

exemplo bidimensional de rede e cela

Figura 1.2

parâmetros axiais para o sistema cúbico

4

Figura 1.3

exemplo de difratograma.

7

Figura 1.4

lei de Bragg

8

Figura 1.5

espalhamento por um eletron

10

Figura 1.6

espalhamento por um eletron na posição $n$

Figura 1.7

exemplo de função de distribuição radial

13

Figura 2.1

geometria "Feixe Paralelo"

20

Figura 2.2

geometria Bragg-Brentano

21

Figura 2.3

geometria Parafocalizante

21

Figura 2.4

geometria transmissão-transmissão

22

Figura 2.5

geometria trasmissão-reflexão

23

Figura 2.6

geometria reflexão-reflexão simétrica

24

Figura 2.7

geometria de Guinier assimétrica

24

Figura 2.8

geometria reflexão-transmissão

25

Figura 2.9

curva de refletividade

26

Figura 2.10

feixe incidente sobre cristal assimétrico

27

Figura 2.11

cristal monocromador de Fankuchen

28

Figura 2.12

cristal monocromador de Johann

29

Figura 2.13

cristal monocromador de Cauchois

29

Figura 2.14

cristal monocromador logarítmo

30

Figura 2.15

curvatura do cristal por 4 cilindros

31

Figura 2.16

curvatura por moldes cilíndricos

32 
Figura 2.17 técnica do corte triangular 32

Figura $2.18 \quad$ diagrama de DuMond 33

Figura 3.1 vista trazeira do Difratômetro 36

Figura $3.2 \quad$ detalhe de funcionamento do Difratômetro 37

Figura 3.3 rolamento entre os discos 38

$\begin{array}{lll}\text { Figura } 3.4 & \text { furação das fitas . } & 40\end{array}$

Figura 3.5a esquema de contrapeso no disco de tras da torre 42

Figura 3.5b esquema do contrapeso no carro 43

Figura 3.6 vista dos rolamentos internos do carro 46

Figura 3.7 detalhe da peça de alinhamento do detetor 47

$\begin{array}{lll}\text { Figura } 3.8 & \text { mancal cônico } & 48\end{array}$

Figura 3.9 geometria usada no cálculo da aceitância 52

Figura 3.10 curva da aceitância 53

Figura 4.1 cadeia nuclear $\quad 59$

$\begin{array}{lll}\text { Figura } 4.2 \quad \text { detetor } & 60\end{array}$

Figura 4.3 conexão PC-SCOPE $\quad 62$

$\begin{array}{lll}\text { Figura } 5.1 & \text { histerese } & 71\end{array}$

$\begin{array}{lll}\text { Figura 5.2 funcionamento do teodolito } & 71\end{array}$

$\begin{array}{lll}\text { Figura 5.3 monocromador com cola } & 78\end{array}$

$\begin{array}{lll}\text { Figura } 5.4 & \text { tensão superficial } & 80\end{array}$

$\begin{array}{lll}\text { Figura } 6.1 & \text { porta-amostra proposto } & 92\end{array}$ 


\section{Lista de Tabelas}

Tabela $1.1 \quad$ sete sistemas cristalinos 3

Tabela 3.1 carga máxima das fitas $\quad 40$

Tabela 3.2 resumo das caracteristicas do difratómetro 45

Tabela 3.3 divergéncia para cada fenda 50

Tabela 4.1 caracteres de controle do SCOPE $\quad 64$

Tabela 4.2 mensagem e explicação dos erros 66

$\begin{array}{lll}\text { Tabela 4.3 parâmetros de transmissão } & 68\end{array}$

Tabela 5.1 posição dos picos por difratometria 74

Tabela 5.2 dados experimentais de calibração 75

$\begin{array}{lll}\text { Tabela } 5.3 & \text { histerese em passos } & 75\end{array}$

$\begin{array}{lll}\text { Tabela } 5.4 & \text { posição dos picos } & 76\end{array}$

Tabela 6.1 deslocamento angular mínimo 89 


\section{Abstract}

This work describes the design, construction and characterization of a $\theta-\theta \times$ ray diffractometer for the study of liquid and polycrystalline materials.

The novelty of the design is in the mechanism that produces the source and detector rotations, based on the principle that two concentric pulleys with the same diameter and attached to belts will equally rotate when these belts are pulled by the same amount. With the proposed design very good reproducibility $\left( \pm 0.002^{\circ}\right)$ and low hysteresis $\left( \pm 0.02^{\circ}\right)$ is achieved with low precision mechanics.

The minimum angular increment of $0.0005^{\circ}$ is performed by a stepp motor that drives a translation carriage which, in its turn, pulls the belts.

The diffractometer was characterized, using CuKa radiation from a conventional laboratory $\mathrm{X}$ ray source, with and without a curved silicon monochromator.

Some examples of diffractograms from powder and liquid samples, obtained with the equipment, are also presented. 


\section{Resumo}

Este trabalho descreve o projeto, construção e caracterização de um difratómetro $\theta-\theta$ de raios $X$ para o estudo de materiais liquidos e policristalinos.

A novidade do projeto esta no mecanismo que produz as rotaçóes da fonte e do detetor, baseadas no princípio que duas polias concéntricas, com o mesmo diâmetro e ligadas a cintas girarão igualmente quando estas cintas forem puxadas com a mesma força. Com o projeto proposto foi obtida boa reprodutibilidade $\left( \pm 0.002^{\circ}\right)$ e baixa histerese $\left( \pm 0.02^{\circ}\right)$ empregando um mecânica de baixa precisão.

$O$ incremento angular mínimo de $0.0005^{\circ}$ é conseguido por um motor de passo que trtranslaciona um carro que, por sua vez, puxa as cintas.

O difratómetro foi caracterizado usando radiação CuK $\alpha$ com uma fonte de laboratório convencional de raios $\mathrm{X}$, com e sem um monocromador curvo de silfcio.

Alguns exemplos de difratogramas de amostras policristalinas e Ilquidas, obtidas com o equipamento, são também apresentadas. 


\section{Introdução}

Esta dissertação mostra o trabalho realizado para construção de um difratômetro $\theta-\theta$. Ela foi dividida em 6 capítulos, começando com uma descrição das amostras aceitas pelo difratômetro e terminando com uma avaliação dos resultados. Exceto o primeiro capítulo, que trata dos tipo de amostras aceitas pelo difratômetro, os demais abordam 0 aparelho sob diferentes aspectos .

O Capítulo I trata dos policristais e dos líquidos. Em cada um destes assuntos é feita uma descrição estrutural da matéria. Em seguida enfatizamos as informações estruturais que podemos obter de um difratograma. O capítulo tem como objetivo introduzir o difratômetro sob este ponto de vista.

O Capítlo II trata da óptica de raios $X$ envolvida nos difratômetros. . Sob este título estão agrupados alguns tópicos desta matéria que são importantes na compreenção deste equipamento. $O$ capítulo foi dividido em três seçōes. Na seção II.1 ("Geometrias") fazemos um apanhado das geometrias utilizadas em difração de raios $X$, indiscriminadamente para líquidos $\theta$ policristais. Na seção II.2 ("Monocromadores") são mostrados alguns monocromadores, algumas técnicas de curvatura do cristal e um método (Diagrama de DuMond) de estudo dos elementos ópticos.

O Capítulo III descreve o difratômetro sob dois aspectos: mecânco e óptico. Além disto sugere uma sequência de açōes para o alinhamento. A descrição mecânica não só introduz o mecanismo responsável pela movimentação do difratômetro mas também enfatiza alguns detalhes de construção e montagem. Calculamos também a variação angular mínima $\theta$ aconselhamos alguns cuidados para manutenção do equipamento. Finalmente, descreveremos os porta-amostras utilizados e os dispositivos de alinhamento. Na descrição óptica serão fornecidos os parâmetros dos elementos ópticos utilizados.

O Capítulo IV aborda o hardware e o software empregados no projeto. Na seção IV.1 serão descritos os módulos eletrônicos do ponto de vista funcional, estando fora do escopo deste trabalho o detalhamento dos circuitos. Na seção IV.2 mostraremos como é feita a comunicação entre o difratômetro (através da Interface SCOPE) e o usuário (através da interface serial do microcomputador). Apresentamos em seguida os programas que desenvolvemos. 
O Capítulo V mostrara como o difratómetro foi avaliado. Descrevera os testes realizados e seus resultados. Em seguida faremos algumas observações realizadas durante os trabalhos experimentais. $\mathrm{Na}$ última seção do capítulo o leitor encontrará alguns difratogramas obtidos com o equipamento.

O Capítulo VI faz um sumário do trabalho realizado e apresenta as conclusões. 


\section{Capítulo I}

Espalhamento Elástico de Raios X 


\section{I.1 Policristals}

As amostras policristalinas são formadas por cristalitos com alguns microns de diâmetro [KLUG,1974], orientados aleatoriamente. Desta forma o pó resultante expōe todos os planos de difração do monocristal.

\section{I.1.1 Estrutura}

Historicamente a concepção e a abordagem das redes cristalinas são extensōes diretas das observações macroscópicas feitas nos minerais. No século XVII Huygens explicou a forma externa e a clivagem da calcita $\left(\mathrm{CaCO}_{3}\right)$, visualizando-a como um empacotamento regular de corpos esféricos.

No séclo XVIII, Haüy sugeriu que se um pedaço de calcita fosse repetidamente clivado, os fragmentos, que sempre teriam a forma do cristal original, poderiam eventualmente ser reduzidos a pequenos paralelepípedos com a mesma forma do cristal original, e contendo uma molécula.

Antes da descoberta dos raios $\mathrm{X}$ a abordagem macroscópica deu origem à cristalografia óptica, que classifica os cristais através da sua atividade óptica, da Lei da Constância dos Ângulos Interfaciais e da Lei dos Interceptos Racionais:

Lei da Constância dos Ângulos Interfaciais: "em uma dada espécie química ou mineral, independentemente das irregularidades de crescimento presentes, os ângulos entre as faces adjacentes ou projetadas, escolhidas de maneira semelhante, são essencialmente constantes "

Lei dos interceptos Racionais: "as relações entre os interceptos das faces de um cristal devem ser números racionais".

Usando estes conceitos os cristais foram classificados em sete sistemas conforme os ângulos entre suas faces e 0 tamanho relativo dos parâmetros axiais. $\mathrm{Na}$ tabela a seguir mostramos a classificação usada. 


\begin{tabular}{|l|}
\hline Cúbico \\
Tetragonal \\
Ortorrômbico \\
Romboédrico \\
Hexagonal \\
Monoclínico \\
Triclínico
\end{tabular}

Tabela 1.1: os sete sistemas cristalinos

Do ponto de vista dos cristalógrafos do século passado os cristais eram formados pela justaposição de unidades básicas, as celas unitárias. Por sua vez as celas eram formadas a partir de uma rede tridimensional de pontos distribuídos regularmente no volume ocupado pelo cristal.

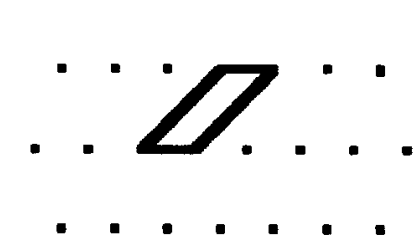

Figura 1.1: exemplo bidimensional de rede e cela

Em 1848 Bravais demonstrou que existem 14 retículos possiveis, que receberam o nome de "Retículos de Bravais".

Com a descoberta da difração de raios X em cristais por Laue em 1912, a estrutura interna pode ser estudada, primeiramente através de técnicas fotográficas como a de Debye-Scherrer, Laue e posteriormente com os difratômetros. 
A cristalografia estrutural não só classifica os cristais de acordo com os 14 retículos, mas localiza os átomos e moléculas que formam sua estrutura em relação a um sistema de coordenadas.

Instalando o sistema de coordenadas em uma das celas, qualquer ponto reticular pode ser descrito da forma

$$
\vec{R}=m_{1} \vec{a}_{1}+m_{2} \vec{a}_{2}+m_{3} \vec{a}_{3},
$$

onde $\vec{a}_{i}$ são os parâmetros axiais e $m_{i}$ são números inteiros. Na Figura 1.2 mostramos estes parâmetros para o sistema cúbico.

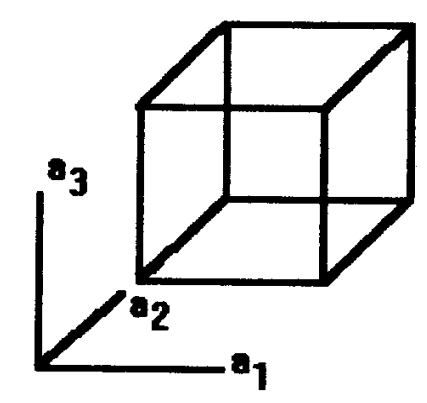

Figura 1.2: parâmetros axiais para o sistema cúbico

O espaço descrito pelos eixos $\vec{a}_{i}$ é chamado de espaço direto, em oposição ao espaço recíproco, definido pelos vetores

$$
\vec{b}_{i}=\frac{\vec{a}_{j} \times \vec{a}_{k}}{\vec{a}_{i} \cdot\left(\vec{a}_{j} \times \vec{a}_{k}\right)},
$$

de tal maneira que $\vec{a}_{i} \cdot \vec{b}_{j}=\delta_{i j}$. 
O espaço reciproco foi criado para facilitar a interpretação dos padrões de difração obtidos nas técnicas fotográficas como explicado, por exemplo, por [BUERGER, 1949], [STOUT,1989] e [AZAROFF,1958].

A visão moderna encara o cristal como formado por um retículo, onde podem ser definidas celas que apresentam algumas simetrias. Do ponto de vista macroscópico existem 32 regras de simetria (chamadas grupos pontuais), encontradas tanto no cristal como na sua cela.

Os 32 grupos puntuais são baseados nos seguintes "elementos de simetria":

$$
\begin{aligned}
& \text { eixos de rotação de ordem } 2,3,4,6 \text {. } \\
& \text { eixos de inversão de ordem } 3,4,6 \\
& \text { plano de reflexão }
\end{aligned}
$$

Alguns grupos apresentam um elemento comum entre si, de forma que as 32 regras de simetria podem ser agrupadas em 7 sistemas (citados anteriormente):

\begin{tabular}{|ll|}
\hline Sistema & Elemento Comum \\
\hline Cúbico & 4 eixos de ordem 3 \\
Tetragonal & 1 eixo de ordem 4 \\
Ortorrômbico & 3 eixos perpendiculares de ordem 2 \\
Romboédrico & 1 eixo de ordem 3 \\
Hexagonal & 1 eixo de ordem 6 \\
Monoclínico & 1 eixo de ordem 2 \\
Triclínico & 1 eixo de ordem 1 \\
\hline
\end{tabular}


Para a descrição da distribuição atômica no retículo são necessários 230 regras de simetria (230 grupos espaciais) compostos com os elementos de simetria dos 32 grupos mais os eixos de reflexão-translação e os espelhos de deslizamento.

Uma abordagem mais rigorosa do assunto pode ser encontrada em [BURNS, 1978].

\section{I.1.2 Conteúdo Informacional do Difratograma}

O difratograma de um policristal geralmente é formado por picos em determinados ângulos, característicos da amostra. Para sua obtenção o pó é levemente compactado numa cubeta. Ela é levada para um difratômetro onde é feita uma varredura nos angulos de incidência do feixe.

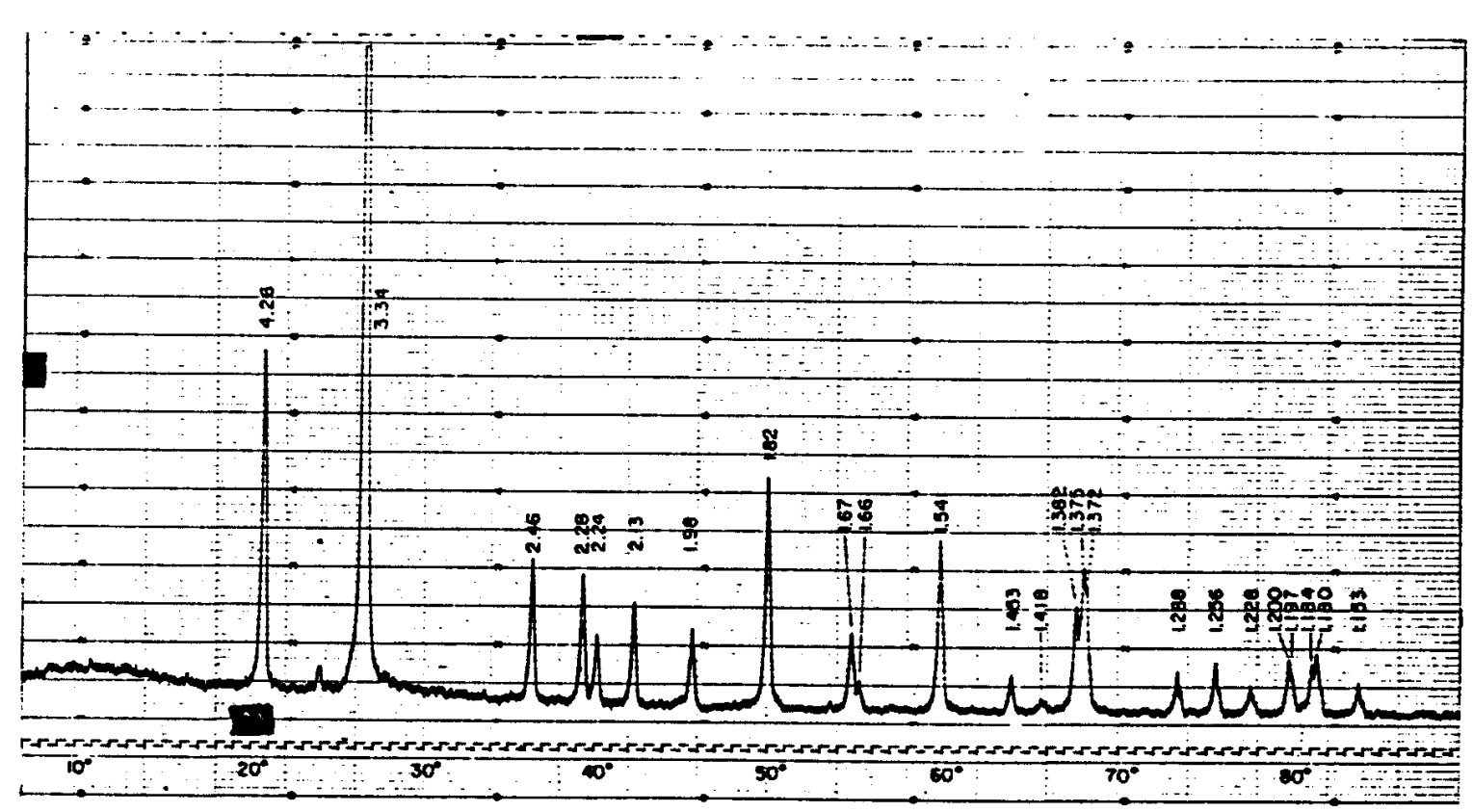

Figura 1.3: exemplo do difratograma de uma amostra policristalina de Quartzo. 
A altura relativa dos picos, sua posição angular e largura são os dados que a técnica oferece. Destes dados podemos deduzir algumas informações sobre a estrutura e composição da amostra.

Bragg utilizou um artifício para explicar a difração, ele supos que o retículo formasse planos onde o feixe incidente seria refletido.

A lei de Bragg fornece uma relação entre a posição angular do pico $(\theta)$ e a distância interplanar (d) de uma determinada família de planos. Ela é deduzida partindo do princípio de que os pontos do retículo formam várias famílias de planos. Cada família sendo formada por um conjunto de planos paralelos igualmente espaçados.

A diferença de caminho óptico entre os raios "refletidos" por dois planos paralelos deve ser igual a um número inteiro $(n)$ do comprimento de onda para que haja interferência construtiva, Figura 1.4 .

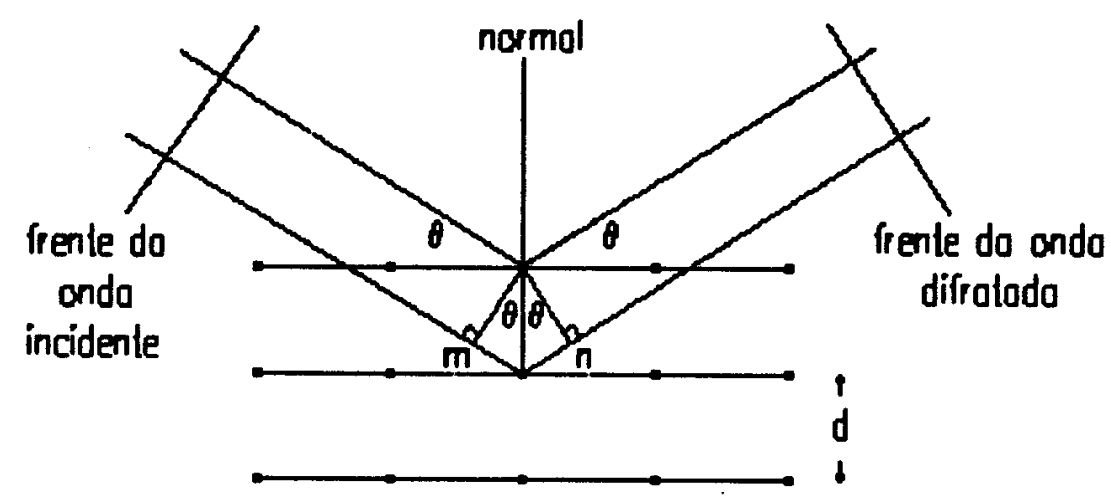

Figura 1.4: lei de Bragg. A distância entre os pontos " $m$ " $\theta$ " $n$ " deve ser igual a um número inteiro do comprimento de onda

A lei de Bragg escrita na sua forma analítica obedece à relação:

$$
n \lambda=2 d \operatorname{sen} \theta \text {. }
$$


Concluímos que a partir da posição angular de um pico de difraçāo, podemos calcular a distância interplanar daquela familia de planos. Cada família de planos de Bragg corresponde a um ponto no espaço recíproco, com coordenadas $(h, k, l)$. A distância interplanar da família é dada por

$$
\frac{1}{d_{h k l}}=\left|h \vec{b}_{1}+k \vec{b}_{2}+l \vec{b}_{3}\right|
$$

onde $b_{i}$ são os vetores de base do espaço recíproco e os inteiros $h, k$ e l são os de índices de Miller.

Definindo $\quad \vec{H}=h \vec{b}_{1}+k \vec{b}_{2}+l \vec{b}_{3}$ podemos calcular $d_{h k l}{ }^{2}$ a partir de

$$
\vec{H} \cdot \vec{H},
$$

obtendo uma relação geral para as distâncias interplanares, válida para todas as famílias de planos de todos os sistemas cristalinos.

Utilizando as restrições observadas em cada sistema, obtemos sete relações que descrevem a distância interplanar em função dos índices de Miller e dos parâmetros de rede.

Com estas relações é possível obter, em princípio, as distâncias interplanares e as dimensōes da cela e o tipo de rede, ou os índices de Miller das reflexões, tendo os demais parâmetros da relação.

Estes dados, a intensidade dos picos e sua largura formam o conjunto de informações que tornam o método de difração de raios $X$ por policristais uma ferramenta útil em várias aplicaçōes.

\subsection{Líquidos}

As amostras líquidas são formadas por átomos e moléculas dispostas numa ordenação preferencial, sensível à temperatura e à vibração mecânica.

A principal diferença entre os cristais e os líquidos é que nos primeiros, os átomos e moléculas possuem uma ordem periódica tridimensional de longo alcace. No caso dos líquidos a ordem é de curto alcance, isto é, a interação existe quase 
No caso dos líquidos a ordem é de curto alcance, isto é, a interação existe quase exclusivamente entre os primeiros vizinhos. Além disto as forças de ligação entre moléculas é muito menos forte que no cristal.

\subsubsection{Estrutura}

Conduziremos a explanação sobre a estrutura dos líquidos, a partir da interação da radiação com os elétrons e átomos. Este tratamento é usado tanto para cristais como para amorfos e obedecem as mesmas equações até o ponto em que entra nas relações a restrição sobre a distribuição espacial dos centros espalhadores [WARREN, 1969].

O maior responsável pelo espalhamento da radiação eletromagnética pela matéria são os elétrons. Uma onda eletromagnética ao incidir sobre um eletron sofre um espalhamento descrito pela eletrodinâmica da forma que descreveremos a seguir.

Uma onda

$$
\vec{\varepsilon}_{o}(\vec{r})=\vec{E}_{o} \exp \left(2 \pi v t-2 \pi \vec{s}_{o} \cdot \vec{r}\right)
$$

com freqüencia $v$, que se desloca na direção de $\vec{S}_{o}$,

$$
|\vec{S}|=|\vec{S}|=\frac{1}{\lambda}
$$

ao atingir um eletron é espalhada esfericamente. 0 módulo do campo espalhado, medido a uma distância $R$ muito grande comparada com o seu comprimento de onda, é dado por

$$
\varepsilon=\frac{\text { easen } \alpha}{c^{2} R},
$$

onde:

" $a$ " é a aceleração sofrida pelo elétron, $a=\frac{E_{o} e}{m}$, 
$a$ sen $\alpha$ é a componente da aceleração observada no ponto P ( Figura 1.5)

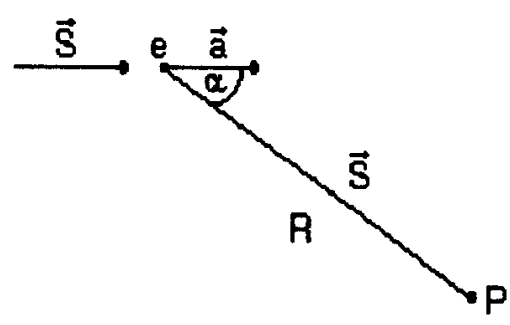

Figura 1.5: espalhamento de uma onda por um eletron na origem. direção $\vec{S}$ :

Quando $\vec{\varepsilon}_{o}(\vec{r})$ incide sobre um átomo ela é espalhada pelo elétron n na

$$
\vec{\varepsilon}_{n}=\frac{E_{o} e^{2}}{m c^{2}\left|\vec{R}-\vec{r}_{n}\right|} \exp \left[2 \pi\left(v t-\vec{S}_{o} \cdot \vec{r}_{n}+\vec{S} \cdot\left(\vec{R}-\vec{r}_{n}\right)\right)\right]
$$

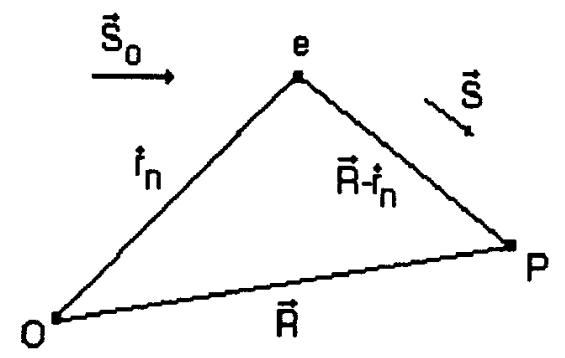

Figura 1.6: onda incidente e espalhada por um eletron na posição $\bar{r}_{n}$

Somando o campo instantâneo para todos os elétrons, o campo espalhado pelo átomo fica 


$$
\varepsilon=\frac{E_{0} e^{2}}{m c^{2} R} e^{2 \pi i[k-R / \lambda]} \sum_{n} e^{2 \pi i\left(\bar{s}-\bar{s}_{0}\right) \cdot \bar{\tau}_{n}}
$$

Chamando de $\rho(\vec{r})$ a quantidade de elétrons por unidade de volume (densidade eletrônica), podemos "generalizar" esta expressão para o campo elétrico da onda espalhada, no caso de um elétron "distribuído" no espaço:

$$
\varepsilon=\frac{E_{0} e^{2}}{m c^{2} R} e^{2 \pi i[v t-\vec{R} \cdot S]} \int e^{2 \pi i\left(\bar{s}-\bar{s}_{0}\right) \cdot \bar{r} / \lambda} \rho d v
$$

onde a integral é o "fator de espalhamento por elétron" $\left(f_{e}\right)$ e representa a amplitude da radiação espalhada ${ }^{1}$ por um elétron, expressa em unidades eletrônicas.

O fator de espalhamento atômico é então definido como a somatória dos f de cada elétron do átomo:

$$
f=\sum_{n} f_{e n}
$$

A amplitude da radiação espalhada pelo átomo é proporcional ao seu fator de espalhamento.

Seguindo a metodologia para cristais, alguns autores [NARTEN, 1979] utilizam o conceito de fator de estrutura (F) no tratamento dos dados experimentais. Sendo o fator $F$ definido como

$$
F=\sum_{n} f_{n} e^{(2 \pi i / \lambda)\left(s-\vec{s}_{0}\right)-\vec{r}_{n}}
$$

$f_{n}$ é o fator de espalhamento atômico e a exponencial é o termo de fase devido à distância entre os átomos. A soma é feita sobre os átomos do centro espalhador,

1 a teoria clássica, que estamos seguindo não leva em conta o efeito Compton 
escolhido (no caso dos líquidos) convenientemente de modo a representar todo o volume de material em estudo.

Como a amplitude espalhada por esta "cela unitária" é proporcional ao seu fator de estrutura $F$, conluimos que a intensidade espalhada com o desvio de direção $\vec{S}-\vec{S}_{o}$ é proporcional a $|F|^{2}$.

Portanto a estrutura de um líquido determina o seu padrão de espalhamento, i.e.: a intensidade por ele espalhada é função da direção em que se mede o espalhamento. $\mathrm{Na}$ seção seguinte veremos o tratamento matemático nos padrōes de espalhamento que levam à informação sobre a estrutura do meio espalhador. 


\subsubsection{Conteúdo Informacional do Difratograma}

O diagrama de espalhamento de um líquido apresenta bandas, no lugar dos picos obtidos com amostras policristalinas.

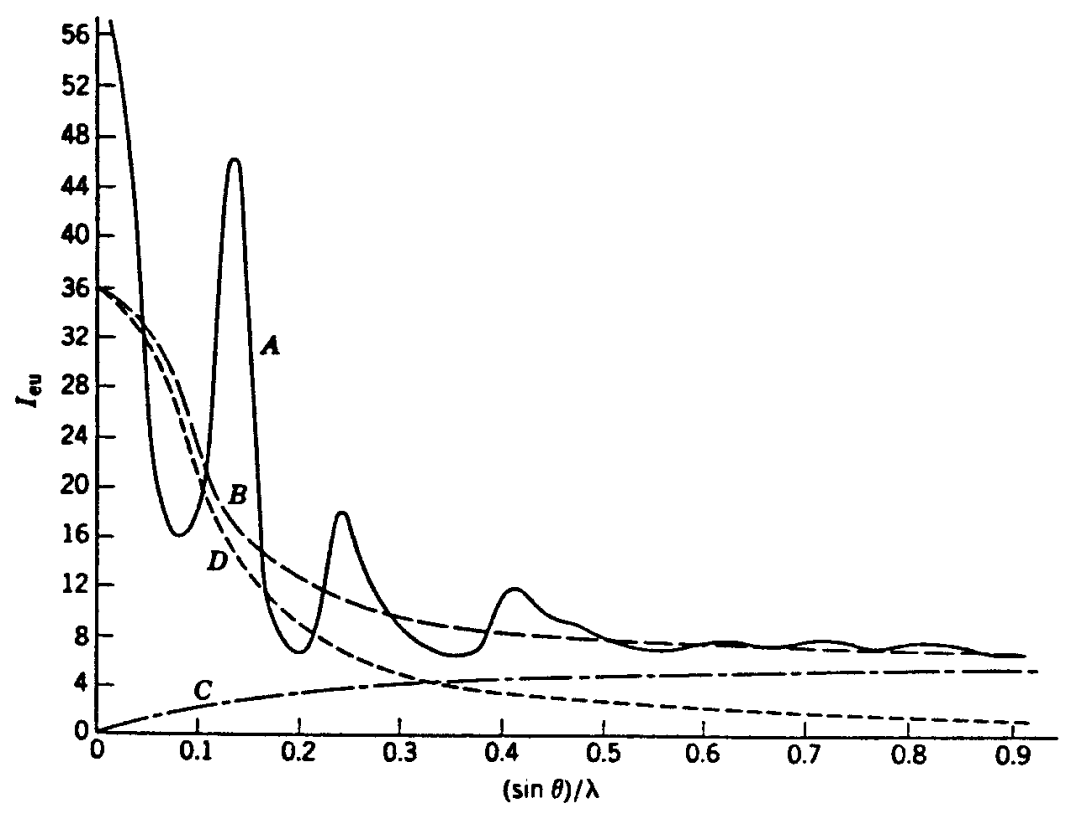

Figura 1.7: curvas experimental e de espalhamento independente para uma amostra de poliisopreno sintética. (A) espalhamento experimental (B) espalhamento independente total (C) espalhamento incoerente; (D) espalhamento coerente independente

Como as bandas são largas, a monocromaticidade da radiação é mais importante do que nos policristais para que não haja uma superposição de curvas que tornará a interpretação dos dados ainda mais difícil.

O diagrama é uma somatória de efeitos, além da difração. O "background", a absorção da amostra, a polarização, o espalhamento incoerente, o espalhamento múltiplo e efeito Compton são os efeitos geralmente corrigidos nos trabalhos que estudam a estrutura de amostras líquidas.

Para o experimentador, porém, o que interessa é a ordenação estrutural da solução. Para facilitar este estudo nomalmente se define um centro espalhador, 
uma espécie de cela unitária que se repete ao longo do líquido. Neste sentido a curva de espalhamento conterá informações sobre a distância entre centros e também a distância entre átomos do centro.

Na prática, porém, é difícil trabalhar com elementos leves devido ao seu baixo poder de espalhamento. Além disto, soluções formadas por moléculas complexas formam curvas muito dificeis de serem interpretadas. Nestes casos uma das técnicas usadas é a da substituição isomórfica, onde se substitui um átomo leve por um átomo pesado, sem alterar a estrutura da molécula.

Partindo da relação entre o fator de estrutura e a intensidade do feixe espalhado

$$
I=\sum_{n} f_{n} e^{(2 \pi i / \lambda)\left(\vec{s}-\vec{s}_{o}\right) \cdot \vec{r}_{n}} \sum_{m} f_{m} e^{(-2 \pi i / \lambda)\left(\vec{s}-\vec{s}_{o}\right) \cdot \vec{r}_{m}}
$$

Zernicke e Prinz [ZERNICKE, 1927] deduziram pela primeira vez em 1927, a função de distribuição radial:

$$
4 \pi r^{2} \rho(r)=4 \pi r^{2} \rho_{a}+\frac{2 r}{\pi} \int_{o}^{\infty} q i(q) \operatorname{sen}(r q) d q
$$

que relaciona a densidade eletrônica $\rho(r)$ com a intensidade corrigida $i(q)$ (obtida a partir da intensidade do feixe espalhado). O significado de cada um dos símbolos da relação acima:

$\rho(r)$ - função de distribuição radial que fornece densidade de centros espalhadores $\rho_{\mathbf{a}}$ - densidade média

$q$ - vetor espalhamento cujo módulo é dado por $q=\frac{4 \pi}{\lambda} \operatorname{sen} \theta$

$i(q)$ - intensidade corrigida, obtida dos dados experimentais conforme explicado abaixo

r - distância entre centros espalhadores. 
Apesar de ter sido corrigida para líquidos monoatômicos, ela é também utilizada para soluções poliatômicas, tomando-se o cuidado, nestes casos, de se escolher centros espalhadores com baixa interação entre si, como os átomos dos líquidos monoatômicos.

$\mathrm{Na}$ descrição de soluçōes a função de distribuição radial é utilizada na determinação da distância média entre os centros espalhadores. As informações concernentes à distância intra-centro podem ser obtidas a partir da equação de Debye [DEBYE, 1915],

$$
i(q)=2 \sum_{j k} \frac{f_{k}(q) f_{j}(q)}{r_{k j} q} \operatorname{sen}\left(r_{k j} q\right) \exp \left(\frac{-1}{2} l_{k g}^{2} q^{2}\right)
$$

onde $l_{k j}{ }^{2}$ é a média do quadrado da variação da distância entre os centros $k$ e j.

Normalmente a utilização destas relações pressupõe um modelo a ser testado. Neste caso o pesquisador, através de outras técnicas, colheu informaçōes sobre a disposição mais provável das moléculas e deseja validar seu modelo. Para isto ajusta as relações acima com os dados experimentais, obtendo as distâncias entre átomos.

a) Tratamento dos dados

A escolha do tratamento mais adequado aos dados experimentais é a fase mais delicada quando se faz a análise estrutural de uma solução. Alguns procedimentos, que mencionaremos a seguir, são comuns a este tipo de estudo.

Como a intensidade do feixe difratado é obtida em valores arbitrários, devese normaliza-lo a uma escala adequada. A "unidade eletrônica" (u.e.) é muito conveniente pois o fator de espalhamento atômico e o fator de estrutura são obtidos nesta unidade.

A normalização é feita fazendo coincidir a curva de espalhamento coerente independente (dada pelo quadrado do fator de estrutura do centro espalhador) com a curva experimental, em ângulos altos (e.g. 60\%). Nesta região espera-se não haver mais efeito de interação entre centros na curva de dados. 
Como dissemos a curva de espạhamento contém não só as informações estruturais mas também o resultado de vários outros efeitos. Um procedimento simples para efetuar várias destas correçōes é obter a curva de espalhamento do solvente e subtraí-lo da curva da solução. Outra maneira é utilizar as relações teóricas para cada efeito e a partir dos valores assim obtidos subtraí-los dos dados experimentais. Para maiores detalhes sobre as relações teóricas desenvolvidas ver por exemplo: [PETKOV, 1989], [MILBERG, 1958], [CROMER, 1967], [CROMER, 1968], [WARREN, 1966], [WARREN, 1970], [CROMER, 1965], [LEVY, 1959], [PINGS, 1968], [ERGUN, 1970], [HAJDU, 1972].

Normalizadas, as intensidades I(s), elas são corrigidas (i(s)), de acordo com a relação [JOHANSSON, 1989],

$$
i(q)=I(q)-\sum n_{j} f_{j}^{2}(q),
$$

onde da intensidade obtida experimentalmente é subtraída a parte correspondente ao espalhamento coerente independente.

Os dados assim tratados podem ser levados ao computador e estudados a partir das relações de Debye e Zernicke. 


\section{Capítulo II}

\section{Óptica dos Difratômetros de Raios X}


Neste capítulo faremos uma breve revisão dos vários arranjos utilizados em difratometria, sob o ponto de vista da óptica envolvida.

A difratometria de raios $X$ é uma técnica experimental que fornece a intensidade difratada por um material em função do ângulo de espalhamento (difratograma), para uma dada energia de fótons. Os difratogramas são obtidos em um equipamento chamado de difratômetro de raios $X$, que é constituído de uma parte mecânica que promove a varredura angular . de elementos ópticos tais como fonte de raios $X$, amostra, fendas, monocromador, filtro e detetor.

A fonte de raios $X$, normalmente um tubo selado com janelas de Be, produz um espectro branco de radiação de freamento superposto a um conjunto de linhas características de fluorescência do alvo utilizado, estendendo-se de alguns keV até o valor correspondente à tensão aplicada entre catodo e anodo (em geral, de 10kV a 50 $\mathrm{kV}$ ). Este espectro pode ser limitado através de filtros ou monocromadores.

As fendas limitam o percurso e divergência do feixe, controlando assim tanto as resoluções angular e de energia, como a radiação de fundo incidente sobre o detetor (normalmente um cristal cintilador acoplado a uma fotomultiplicadora).

As divergências de feixe e as resoluçōes são normalmente expressas em termos da largura a meia altura (FWHM, full width at half maximum) de uma distribuição que pode, ou não, ser gaussiana. $O$ quociente deste parâmetro pela largura a um-décimo da altura (FWTM, full width at tenth maximum), FWHM/FWTM, serve como um indicativo de desvios em relação a uma distribuição gaussiana.

A divergência angular do feixe é analisada em termos de duas componentes:

(i) divergência radial, medida no plano de espalhamento, i.e., o plano definido pelo eixo do feixe incidente e o eixo do feixe difratado;

(ii) divergência axial, medida em um plano perpendicular ao plano de espalhamento.

Neste trabalho chamamos de geometria à idealização da disposição dos elementos ópticos no difratômetro.

\subsection{Geometrias Mais Utilizadas em Difratometria}

As geometrias utilizadas em difratometria podem ser divididas em duas classes, segundo o uso, ou não, da focalização do feixe de raios $X$. $O$ uso de focalização permite um melhor compromisso entre intensidade difratada disponivel no detetor $e$ resolução angular.

A geometria de Bragg-Brentano foi a primeira a utilizar focalização, que era obtida através de amostras policristalizas curvas. A curvatura da amostra, embora maximize a intensidade difratada para uma dada resolução angular, torna difícil o acesso aos ângulos baixos. Daí a introdução da parafocalização, que utiliza amostras planas. 
Normalmente as amostras são utilizadas em reflexão, i.e.: o feixe difratado deixa a amostra pela mesma face em que incide. Contudo, quando finas e montadas sobre substratos amorfos $\theta$ transparentes aos raios $X$, elas podem ser utilizadas em transmissão, i.e.: o feixe difratado deixa-as pela face oposta àquela em que incide. $O$ mesmo se aplica aos monocromadores, que podem ser projetados para o caso Laue (transmissão) ou Bragg (reflexão).

Estas opções, adicionadas do uso, ou não de monocromadores levam à seguinte classificação das geometrias de difratômetros:

Não-Focalizantes Feixe-Paralelo

Focalizantes Bragg-Brentano

Parafocalizante sem monocromador

Parafocalizantes com monocromador

(amostra-monocromador);

Transmissão-Transmissão

Transmissão-Reflexão

Reflexão-Reflexão

Reflexão-Transmissão

Sob o ponto de vista da mecánica de rotação, há três tipos de varredura angular: (i) $2 \theta$, (ii) $\theta-\theta$, (iii) $\theta-2 \theta$. No primeiro caso a fonte $\theta$ a amostra permanecem imóveis e somente o detetor se movimenta (é o caso da câmara de pó, onde o movimento do detetor é substituído por um filme cilíndrico). No segundo caso, que é utilizado neste trabalho, a amostra permanece imóvel enquanto o tubo de raios $\mathrm{X}$ e 0 detetor giram com a mesma velocidade angular em torno do centro da amostra. No terceiro caso, mais comum entre os equipamentos comerciais, o tubo permanece imóvel enquanto a amostra e o detetor giram em torno do centro da amostra com velocidades angulares na proporção de 1 para 2, respectivamente.

$\mathrm{Na}$ apresentação das geometrias a seguir, utilizaremos as definições de:

círculo de focalizacão (ou círculo de Rowland): que passa por três pontos, dois focos (e.g. o alvo da fonte e sua imagem) e o objeto iluminado (e.g. amostra).

círculo difratométrico: círculo centrado no objeto iluminado (amostra ou monocromador) e que passa por um foco (e.g. o alvo da fonte).

a) Feixe Paralelo

Nesta geometria o feixe não é focalizado. O tubo é trazido o mais próximo possível do cristal monocromador plano para evitar perda de intensidade. O feixe incide sobre a amostra dentro de um capilar $\theta$ é detectado por um detetor (ou por um filme) colocado ao longo de um círculo difratométrico.

A resolução nesta geometria é determinada por dois fatores: 1- a largura intrínseca do cristal monocromador $\Theta 2$ - a distância entre o cristal $\Theta$ a amostra. 
Quanto maior a largura intrínseca, menor a resolução em energia. Quanto maior a distância cristal-amostra, maior a resolução angular. O aumento desta distância, porém, tem o efeito de diminuir a relação sinal/ruido.

Alguns autores como [HERMS, 1984] e [KURAHASHI, 1991] fizeram estudos comparativos entre geometrias e apontam a boa resolução angular e a intensidade adequada como características desta configuração.

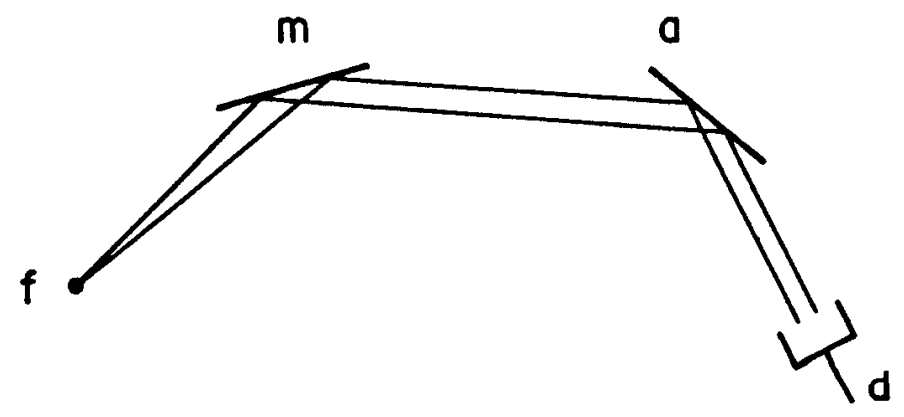

Figura 2.1: geometria "Feixe Paralelo". (f) fonte, (m) monocromador, (a) amostra, (d) betetor

b) Geometria de Bragg-Brentano

A geometria de Bragg-Brentano está fundamentada em dois pontos: aleatórias.

(i) A amostra é policristalina, i.e., contém inúmeros cristais com orientações

(ii) Dados dois pontos, $\mathrm{D}$ e F, sobre um círculo o ângulo $\alpha$ entre as cordas FA e $A D$ é independente da posição de $A$ sobre o arco FD.

Assim, se curvarmos a amostra policristalina sobre o círculo e usarmos uma reflexão tal que $2 \theta=180^{\circ}-\alpha$, sempre haverá um microcristal, em qualquer posição que irá difratar um raio de $F$ sobre o ponto $D$.

Se $d=F D$, então $d=2 R \operatorname{sen}(2 \theta)$. Dados $d$ e $2 \theta$, fica definido o círculo de focalização, passando por $F$ e $D$ com raio

$$
R=\frac{d}{2 \operatorname{sen}(2 \theta)}
$$




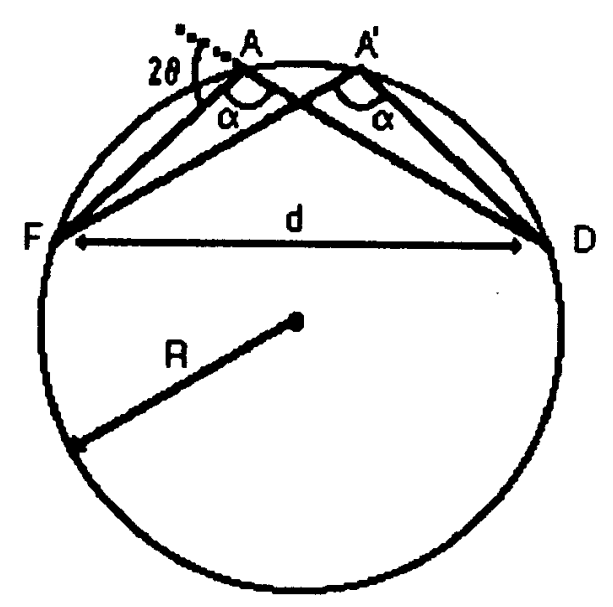

Figura 2.2: Geometria Bragg-Brentano

Este é um exemplo em que todas as linhas de difraçăo ocorrem simultaneamente, sendo possivel tanto usar um filme ou um detetor pontual. Neste caso a varredura é feita movimentando somente o detetor.

Esta geometria apresenta duas desvantagens: 1- difícil acesso a ângulos baixos. 2- o intervalo angular $(2 \theta)$ é limitado pela posição relativa do tubo e da amostra.

c) Parafocalizante

Esta é uma variação da geometria de Bragg-Brentano. A diferença consiste em deixar a amostra plana, tangenciando o círculo de focalização (ou círculo de Rowland) e concentrar o feixe sobre esse ponto (Figura 2.3).

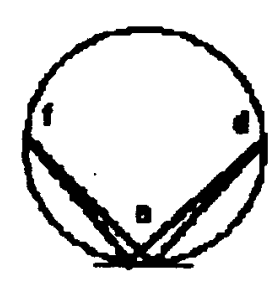

Figura 2.3: Geometria Parafocalizante

d) Transmissão-Transmissão

Neste arranjo $\theta$ nos três outros descritos a seguir, são utilizados monocromadores. A utilização de monocromador, antes ou depois do feixe difratar na amostra, determina dois círculos de focalização (Figura 2.4). 0 primeiro círculo é definido pelo foco do tubo de raios X (f) a amostra (a) e a "imagem" (i1) do foco do tubo produzida pela reflexão na amostra. $O$ segundo círculo é definido por i1, pelo monocromador, m, e pela "imagem" (i2) de i1 através da reflexão no monocromador. 
O difratograma é obtido através da rotação da amostra e do conjunto monocromador/detetor (d), em torno do eixo da primeira. A velocidade de rotação do monocromador/detetor é duas vezes a da amostra.

Esta geometria não é muito usada por atenuar o feixe incidente em dois dos seus elementos ópticos, limitando sua aplicação a amostras muito pouco absorventes.

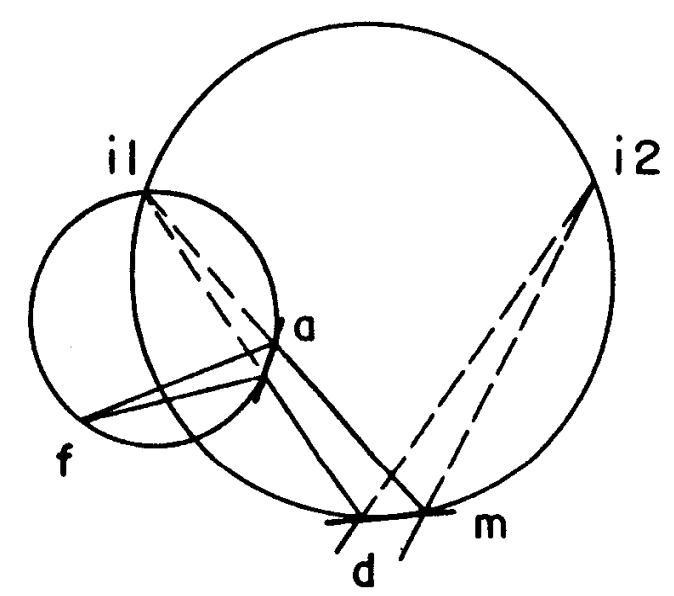

Figura 2.4 : geometria de Transmissão-Transmissão

\section{e) Transmissão-Reflexão}

Nesta geometria a amostra transmite o feixe incidente e o cristal monocromador o reflete. Mostramos na Figura 2.5 uma representação desta geometria utilizando um círculo difratométrico formado pela amostra $(a)$ e pela fonte $(f)$, e por um círculo de focalização, formado pelo monocromador $(m)$ pela imagem da fonte (i1) e seu foco (d), onde é colocado o detetor.

A varredura angular também é feita ratacionando a amostra e o conjunto monocromador-detetor em torno do eixo da amostra.

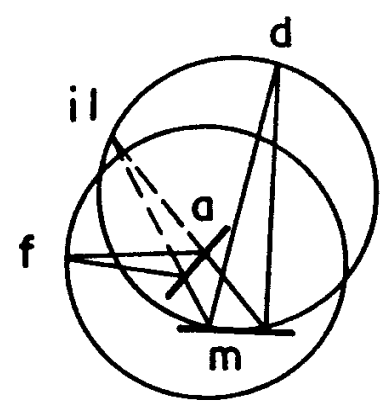

Figura 2.5: geometria Transmissão-Reflexão 


\section{f) Reflexão-Reflexão}

Aqui ocorre reflexão na amostra e no monocromador.

Dependendo como a amostra e o tubo estão posicionados, um em relação ao outro, o arranjo diz-se simétrico ou assimétrico.

Os dois arranjos são encontrados nas câmaras de Guinier, onde o diâmetro típico para o círculo de focalização da amostra fica em torno de $160 \mathrm{~mm}$.

Nestes casos a amostra é curva e novamente surge a limitação com respeito ao intervalo angular alcançado. No arranjo simétrico as câmaras permitem acesso a ângulos que vão de 55 a 90 graus enquanto no arranjo assimétrico o intervalo vai de 30 a 60 graus [KLUG, 1974].

i) simétrico

Neste caso o círculo de focalização "dad", Figura 2.6, passa por focos da fonte (d) distribuídos simetricamente como mostrado na Figura. Cada par "dd" é resultado da difração por uma família de planos da amostra "a".

O padrão de difração pode ser observado em qualquer uma das duas metades, por filme ou detetor. Note que para isto a amostra deve ser curva.

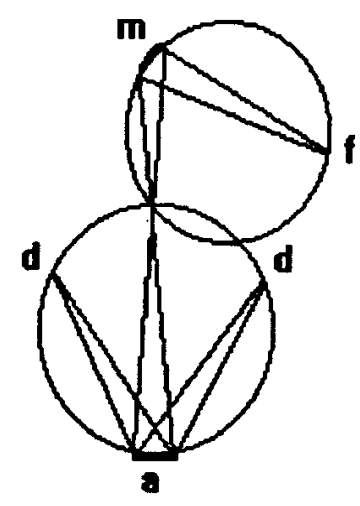

Figura 2.6: Reflexão-Reflexão simétrica

ii) assimétrica

Na disposição assimétrica a amostra é plana $\Theta$ o segundo círculo de focalização (af), Figura 2.7, equivale à geometria "Parafocalizante sem monocromador". 
O difratograma é observado movimentando o conjunto monocromador-detetor e fonte numa varredura $\theta-\theta$ ou 0 conjunto monocromador-detetor $\theta$ amostra numa varredura $\theta-2 \theta$.

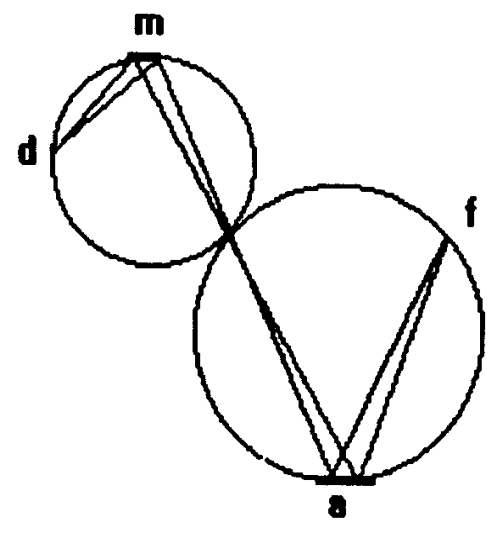

Figura 2.7: a geometria de Guinier asimétrica

g) Reflexão-Transmissão

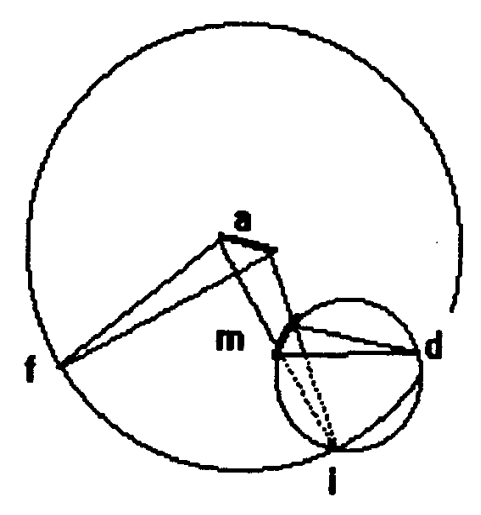

Figura 2.8: Reflexão-Transmissão

Nesta geometria a amostra reflete e o monocromador transmite o feixe incidente. Representamos esta geometria na Figura 2.8 utilizando um círculo difratométrico (fai) e um círculo de focalização (mdi).

Em "i" é formada uma imagem virtual da fonte. Uma imagem real é formada no foco (d) do monocromador onde é posicionado um detetor. Neste ponto é posicionado 0 detetor (d). 
Como na geometria anterior, a varredura angular pode ser feita no modo $\theta-\theta$ ou $\theta-2 \theta$.

\subsection{Monocromadores}

Nesta secção descreveremos a geometria de alguns monocromadores indicando alguns cristais mais usados. Indicaremos também três técnicas de curvatura para cristais monocromadores $\theta$ finalmente dedicaremos alguns parágrafos à apresentação do diagrama de DuMond.

Esta seção foi baseada nas referências "X-Ray Monochromators" de Matsushita e Hashizume [MATSUSHITA, 1983] e "X-Ray Analysis Papers" [PARRISH, 1965]

A descrição adequada dos monocromadores utiliza a teoria dinâmica de difração através de conceitos como refletividade, largura intrínseca, fator de assimetria, etc.

Os monocromadores diferem muito dependendo da qualidade estrutural do cristal utilizado, indo desde o cristal perfeito até o cristal mosaico. Fixando-se nos cristais "perfeitos", descreve-se o comportamento do monocromador em função da curva de refletividade. A refletividade depende do ângulo de incidência do feixe $(\theta)$ próximo ao ângulo de Bragg e da constante dielétrica $\quad(\varepsilon=1-2 \delta-2 i \beta)$ :

$$
R=\frac{(\theta-a)^{2}+b^{2}}{(\theta+a)^{2}+b^{2}},
$$

onde

$$
\begin{aligned}
& 2 a^{2}=\left[\left(\theta^{2}-2 \delta\right)^{2}+4 \beta^{2}\right]^{1 / 2}+\theta^{2}-2 \delta \\
& 2 b^{2}=\left[\left(\theta^{2}-2 \delta\right)^{2}+4 \beta^{2}\right]^{1 / 2}-\theta^{2}+2 \delta .
\end{aligned}
$$




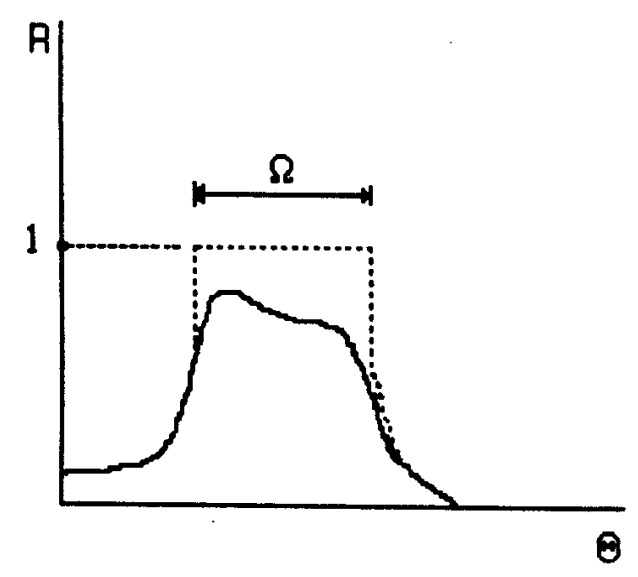

Figura 2.9: curva de refletividade que mostra a região angular na qual ocorre fenômeno da difração. R-refletividade; $\Omega$-largura intrínseca.

A refletividade é adimensional e se restringe ao intervalo de 0 a 1 . A largura intrínseca, $\Omega$, é dada em unidades angulares é é da ordem de segundos de arco para cristais perfeitos, correspondendo à região de reflexão total quando a absorção é desprezada.

O corte do cristal determina o ângulo entre a superfície do cristal e a família de planos de difração $(\alpha)$. Se $\alpha=0$ diz-se que o monocromador é simétrico. No caso de reflexão assimétrica $(\alpha \neq 0)$ existem duas larguras intrínsecas: uma de entrada $\left(\omega_{e}\right.$, "aceitância") e outra de saída $\left(\omega_{s}\right)$ da reflexão.

Estas grandezas estão relacionadas com a largura intrínseca do cristal simétrico $(\Omega)$ através do fator de assimetria

$$
b=\frac{\left|\operatorname{sen}\left(\theta_{B}-\alpha\right)\right|}{\operatorname{sen}\left(\theta_{B}+\alpha\right)}
$$

da forma:

$$
\omega_{e}=\sqrt{b} \Omega
$$




$$
\omega_{s}=\frac{\Omega}{\sqrt{b}} .
$$

No caso assimétrico as dimensões espaciais dos feixes também são alteradas pela reflexão assimétrica. Mostramos estas duas propriedades, aceitância e largura do feixe, para um cristal assimétrico na Figura 2.10. O uso da assimetria pode resultar, em alguns casos, em um melhor aproveitamento do feixe produzido pela fonte de raios $\mathrm{X}$.

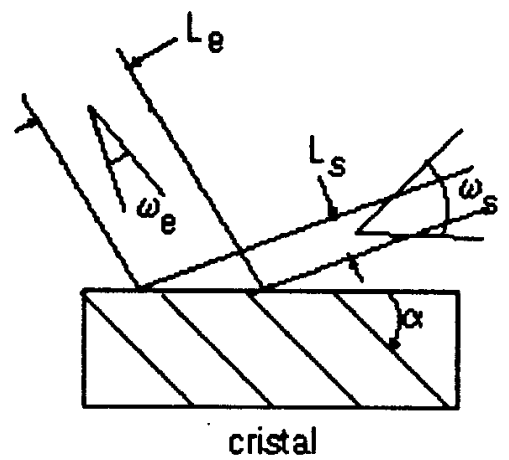

Figura 2.10: um feixe incide sobre um cristal assimétrico. A seção transversal do feixe incidente $\left(L_{\Theta}\right)$ é maior que a do feixe refletido $\left(L_{s}\right)$, mas sua aceitância $\left(\omega_{\Theta}\right)$ é menor.

\section{a) Geometrias}

O monocromador mais simples é construído a partir de um cristal plano cuja face de corte é paralela a uma família de planos de difração (Figura 2.10). Como a refletividade varia linearmente com o módulo do fator de estrutura, o corte $\theta$ feito preferencialmente ao longo dos planos com maior fator de estrutura.

Observando a lei de Bragg, vemos que o cristal pode difratar, para uma distância interplanar " $d$ ", um comprimento de onda $\lambda$ e seus harmônicos, $\lambda / 2, \lambda / 3$, etc. Quando 0 experimento requer um feixe monocromático, busca-se uma solução utilizando cristais como $\mathrm{CaF}_{2}$ e diamante que possuem baixa refletividade em difração de ordem 2 ou acima. Outras soluções são adicionar filtros ou manter 0 tubo de raios $X$ sob um potencial inferior ao necesário para gerar os harmónicos. Este procedimento, porém, tem a desvantagem de reduzir o número de fotons gerados. 


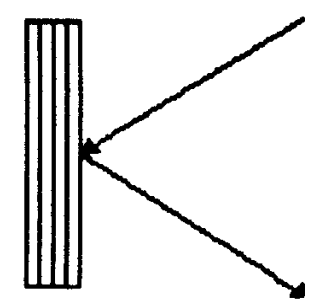

Figura 2.10: monocromador plano

Fankuchen é o nome de outro monocromador obtido fazendo-se um corte assimétrico no cristal, Figura 2.11.

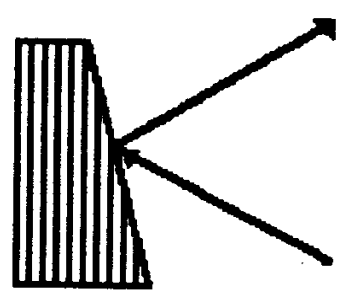

Figura 2.11: corte assimétrico do cristal monocromador de Fankuchen

Curvando o cristal simétrico plano obtemos o cristal de Johann, Figura 2.12.

Neste arranjo o raio de curvatura é duas vezes o raio do círculo de focalização (cáustica). Como vemos na Figura o foco é alargado (não pontual), ao longo da cáustica.

De acordo com [PARRISH, 1965], a partir de estudos feitos por [BROGREN, 1955], a aberração no foco é reduzida pela distorção elástica da estrutura cristalina que compensa parcialmente a descoincidência dos círculos de focalização e curvatura. 


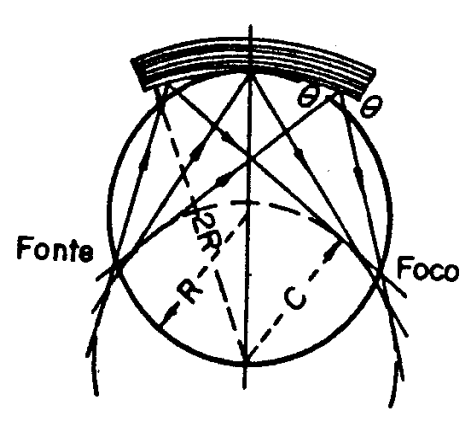

Figura 2.12: cristal monocromador de Johann

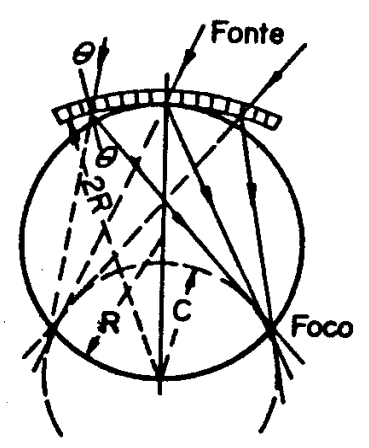

Figura 2.13: cristal monocromador de Cauchois 
Para esta geometria cristais como mica, quartzo e gipsita tem sido usados com espessura de alguns décimos de milímetro.

As principais diferenças em relação ao arranjo de Johann está na perda de intensidade devido à transmissão e sua aplicação para fontes extensas.

O monocromador do tipo espiral-logaritmico tem seu cristal simétrico curvo ao longo de uma curva da forma

$$
r=\exp (A \phi)
$$

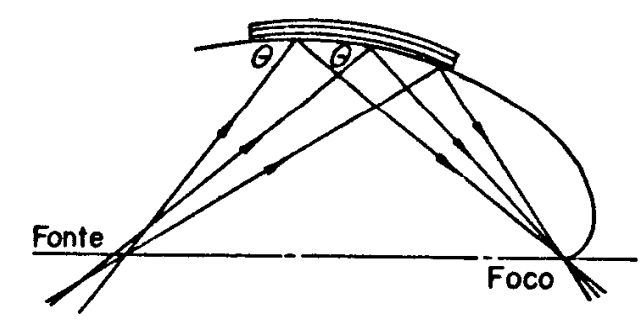

Figura 2.14: cristal monocromador logarítmo

A cáustica deste monocromador também é do tipo $r=\exp (A \phi)$ e encontra a primeira curva no foco. Como vemos na Figura 2.14 este tipo de monocromador permite que um foco puntual seja obtido a partir de uma fonte extensa.

O monocromador de Johannson é construído a partir do cristal de johann, onde é feito um polimento para fazer coincidir o círculo de focalização com o de curvatura. são resolvidas.

Com este procedimento as aberrações presentes no monocromador de Johann

Repetindo o processo de fabricação acima (curvatura e polimento) para um cristal assimétrico obtemos o monocromador de DuMond-Kirkpatrick, que igualmente remove as aberraçōes crônicas do monocromador de Cauchois.

Os monocromadores de múltiplas reflexões utilizam as idéias básicas mencionadas acima. Suas propriedades de focalização, resolução, rejeição de harmônicos, etc, podem ser encontradas em Parrish (1965) e Matsushita (1983).

b) Alguns cristais usados como monocromadores - Cristais mosaicos

Além dos cristais "perfeitos" são utilizados também cristais mosaicos na construção de monocromadores. Estes são formados por monocristais ligeiramente 
desalinhados, ou seja, os planos de difração sofrem uma descontinuidade (devido à inclinação) entre os monocristais.

O cristal mosaico aumenta a intensidade do feixe refletido, em relação ao monocristal, porque seus blocos mosaicos estão em condiçōes de difração para vários comprimentos de onda. Com isto o cristal mosaico perde na resolução em energia.

Tipicamente um monocristal possui um largura intrínseca de alguns segundos de arco, enquanto que o cristal mosaico pode atingir até décimos de grau. Em termos de energia, largura intrínseca do monocristal é da ordem de alguns eletrons-volts, enquanto que para cristais mosaicos é da ordem de centenas de eletrons-volts.

d) Técnicas de curvatura

As técnicas mais utilizadas para se obter a curvatura de cristais em monocromadores são:

i) Quatro cilindros - consiste em deformar elasticamente o cristal através da ação de dois pares de cilindros com espaçamentos distintos.

ii) Prensa - o cristal é prensado entre dois blocos com superfícies usinadas com a curvatura desejada.

iii) Corte triangular - a lâmina cristalina é cortada na forma triangular, fixada através de um dos lados e flexionada através da aplicação de uma força no vértice oposto.

A técnica dos quatro-cilindros, tem a desvantagem de restringir os caminhos ópticos àqueles permitidos pelos cilindros internos.

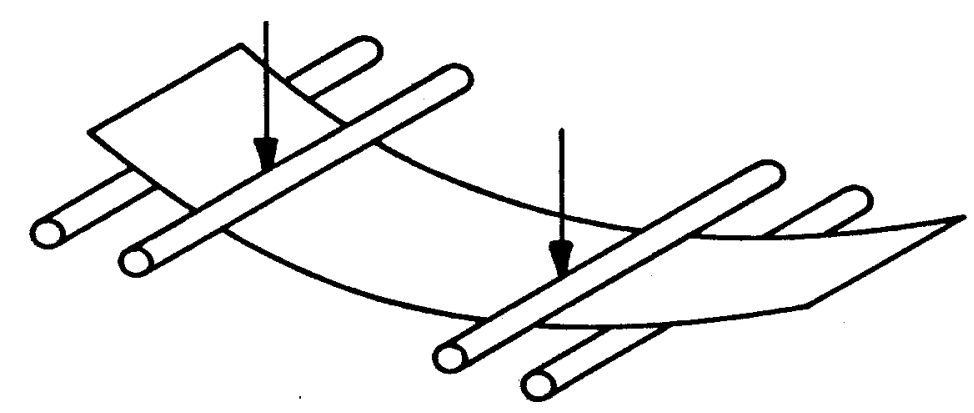

Figura 2.15: técnica da curvatura do cristal por quatro cilindros

Na técnica da Prensa o cristal é protegido pela própria peça que causa a deformação formando um monocromador robusto. Deve-se tomar cuidado, porém, 
para que o cristal fique em contato com os blocos somente nas áreas de pressão para evitar deformações espúrias na lâmina.

Para um cristal de Si com $0.4 \mathrm{~mm}$ de espessura, uma mordedura de $2 \mathrm{~mm}$ em cada borda é suficientemente para flexiona-lo.

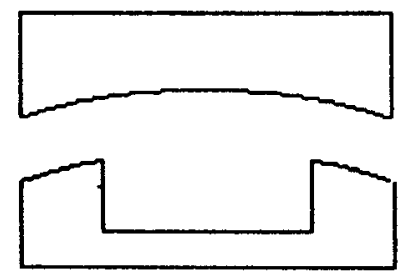

Figura 2.16: curvtura por moldes cilíndricos. Vemos as duas metades entre as quais o cristal é prensado. Para reduzir o contato entre os dois blocos e o cristal podese construir um sulco também na metade côncava .
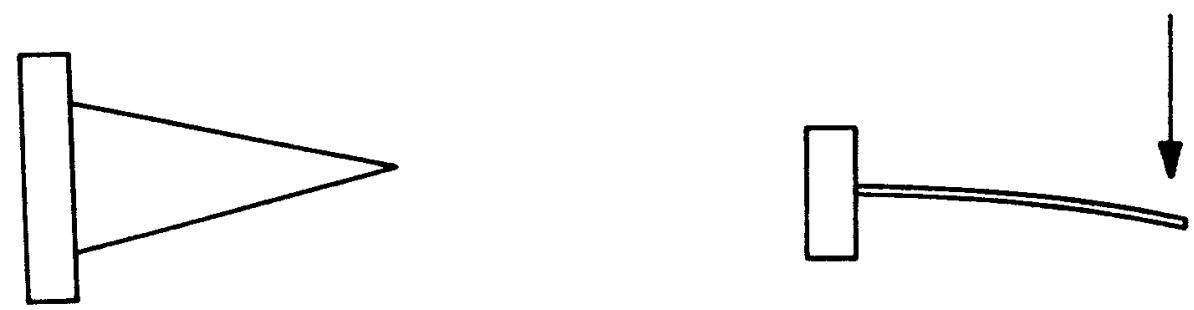

Figura 2.17: técnica do corte triangular para deformação de cristais em monocromadores

e) Métodos gráficos para óptica de raios X, Diagrama de DuMond.

Apesar de não serem essenciais, os métodos gráficos auxiliam na compreensão e no projeto de elementos ópticos dando uma visão intuitiva dos fenômenos envolvidos.

Estes elementos descritos no espaço $\theta-\lambda$ (ângulo-comprimento de onda) formam os diagramas de Dumond, que exemplificaremos a seguir.

Nesta descrição uma fonte de tubo selado gera um espectro limitado $(\Delta \lambda)$ com divergência $(\Delta \theta)$ definida, assinalado como "SR" na Figura 2.18. As fendas que limitam a divergência são mostradas na figura com o símbolo " $\mathrm{S}$ ". 
$O$ cristal (C) segue uma relação senoidal entre $\theta$ e $\lambda$, mas como o cristal possue uma largura intrínseca a senoide deve ser representada por uma faixa senoidal com largura correspondente à largura intrínseca do cristal.

Neste exemplo vemos que o cristal refletirá apenas na região de intersecção entre C,S e SR.

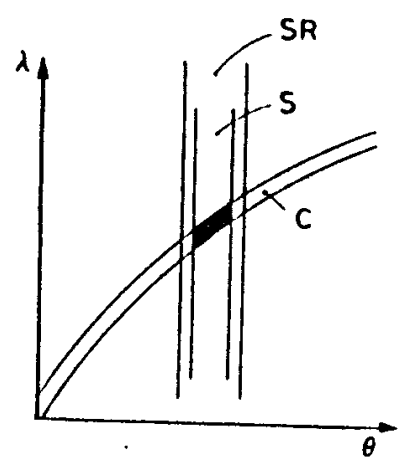

Figura 2.18: diagrama de DuMond

Como a fenda soller tem a função de limitar a divergência axial, ela não é. representada no diagrama de DuMond, que descreve apenas a divergência radial $\Delta \theta$. 
Capítulo III

O Difratômetro Proposto 


\section{III.1 Descrição Mecânica}

- goniômetro por nós projetado e testado segue a geometria de parafocalização. Com o acréscimo de um monocromador ela passou a ser de reflexão-reflexão, segundo a nomenclatura seguida no capítulo II, seção II.2.

a) Mecanismo

A novidade deste goniômetro está no seu mecanismo de movimentação. Ao invés de engrenagens usamos um sistema com fitas de aço.

Cada fita trabalha tracionada entre um disco de aço e uma das laterais de um carro (Figura 3.1). Sendo as fitas flexíveis e mantidas sob tração graças aos torques aplicados pelos braços da fonte de raios $X$ e do detetor, o movimento do carro faz com que elas se enrrolem sobre os discos concêntricos, transformando um único movimento de translação x em duas rotações contrárias e sincronizadas .

O carro, as fitas e os dois discos concêntricos estão na parte de traz do difratômetro. Na parte da frente estão a torre e o detetor fixos em dois outros discos, Figura 3.3. Eles produzem um torque nos discos de traz graças à forma como estão ligados. Os dois discos que movimentam o braço da torre, um atrás e um na frente, estão rigidamente ligados, assim como os dois que movimentam o braço do detetor. Entre os dois conjuntos, entretanto, existem dois rolamentos de esfera que permitem um movimento concêntrico dos dois mecanismos. Um outro par de rolamentos, coaxial com o primeiro, desacopla a rotação dos cilindros em relação à carcaça do equipamento (rolamentos mais externos mostrados na Figura 3.4). 


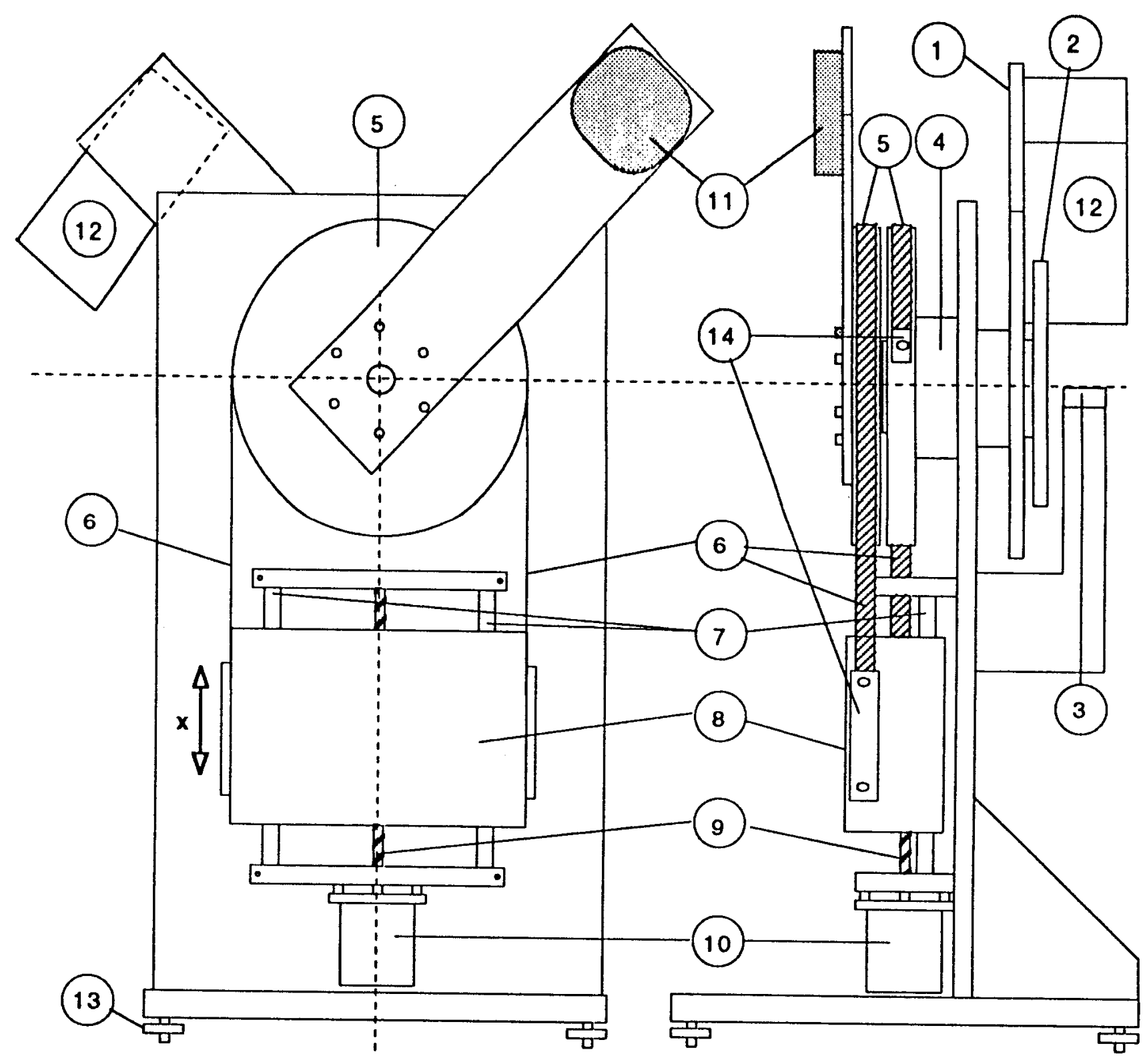

1-Braço da fonte de raio- $X$ e fendas de fonte

2-Braço do detetor de rajo- $X$, fendas e monocromador

3-Porta-amostras

4-Conjunto de dois eixos concentricos

5-Discos com o mesmo raio $\mathrm{A}$

6-Fitas de aço

7-Guias cilindricos retificados para os rolamentos lineares

8-Carro de translação com rolamentos lineares

9-eixo sem fim

10-Motor de passos

11-Contra-peso do tubo de raio- $X$

12-Tubo de raio- $X$

13-Parafusos de nivelamento

14-Presilhas para as fitas de aço

Figura 3.1: vista traseira e perfil do difratômetro. As figuras 3.3, 3.5a, 3.6 e 3.8 mostram os detalhes mais importantes do equipamento 


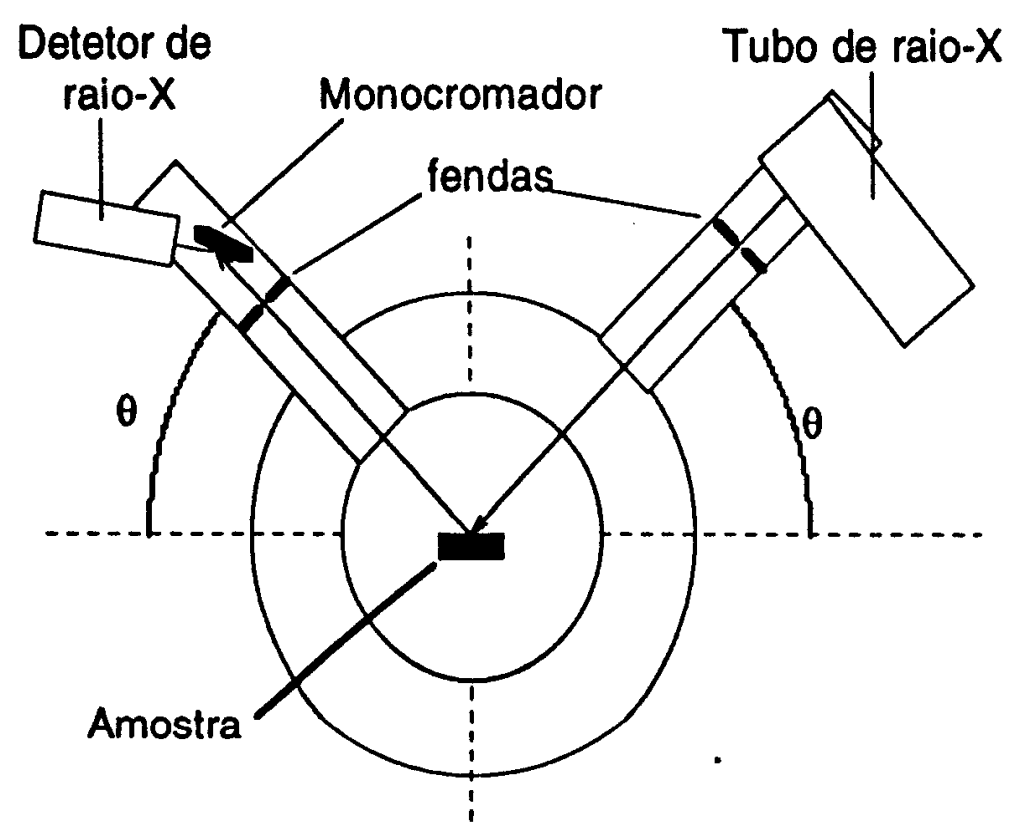

(a)

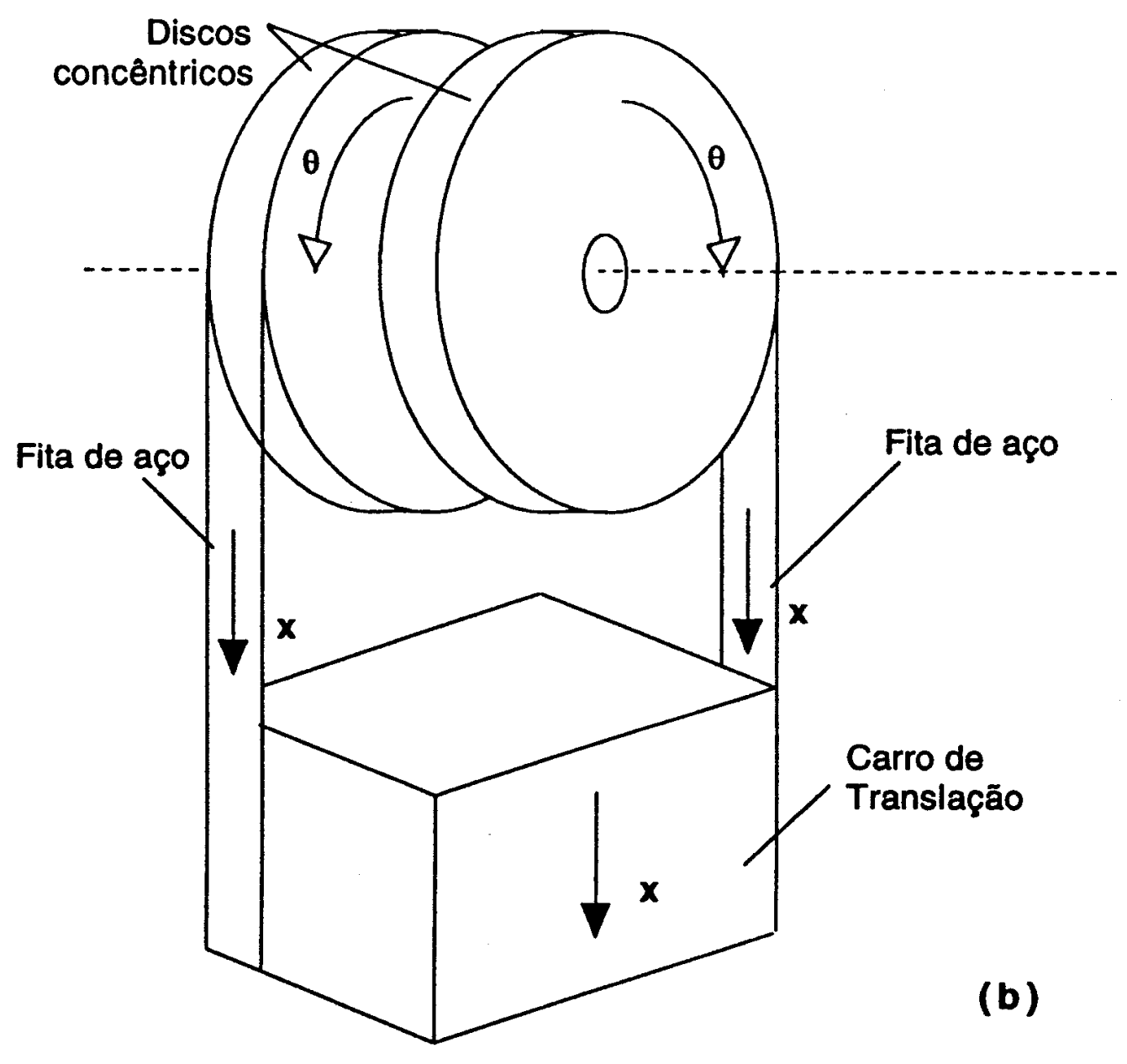

Figura 3.2: detalhe de funcionamento do sistema de movimentação por fitas. 


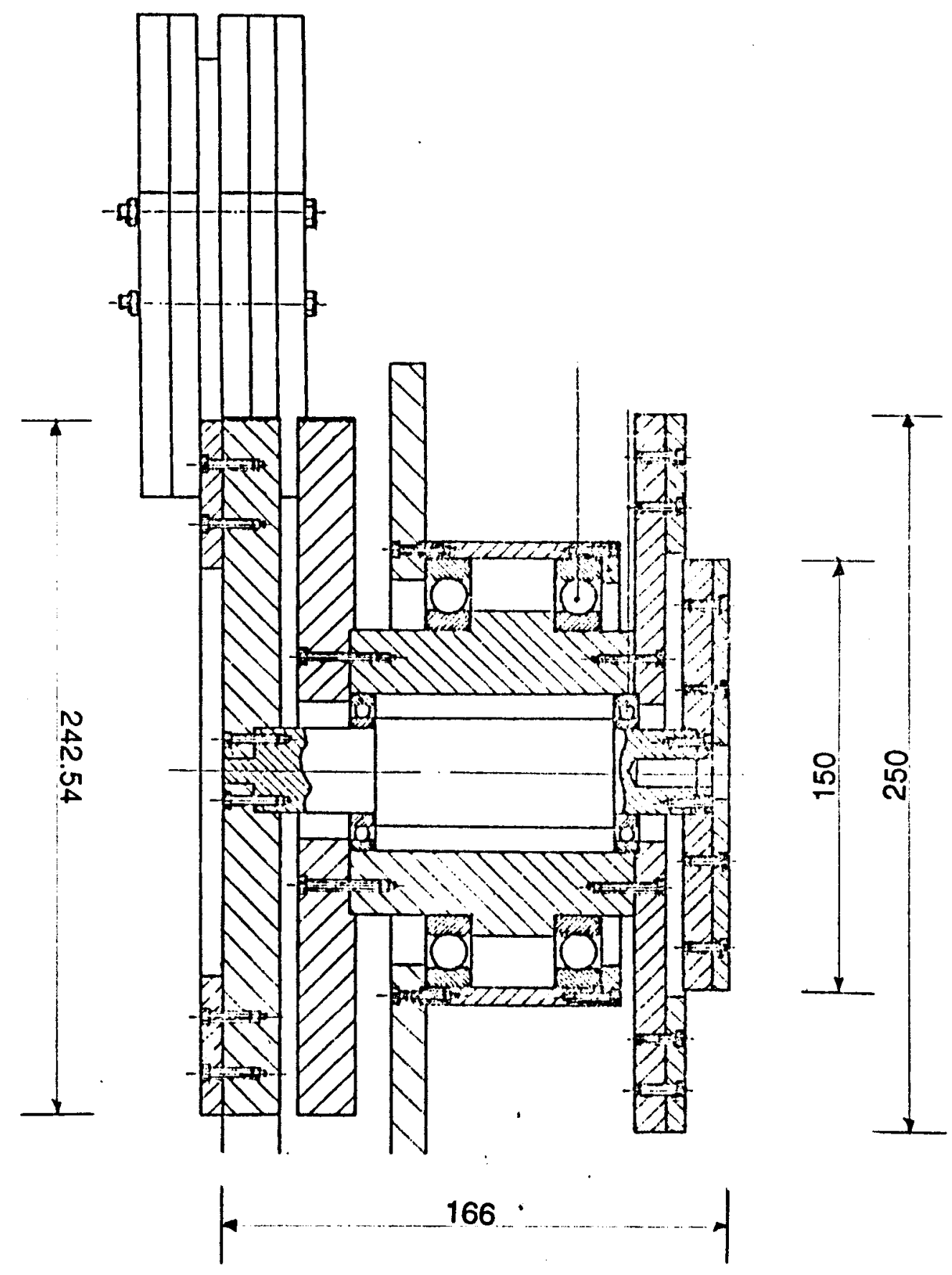

Figura 3.3: rolamentos e conexão entre os discos dianteiros e traseiros. Detallhe simplificado da figura 3.1. Nesta figura os discos traseiros são mostrados no item 5 e os dianteiros suportam os itens 1 e 2 . 
O movimento do carro é regido por um fuso acoplado a um motor de passo. $O$ fuso passa por dentro do carro que possui um rosca fixa em contato com o fuso. Quando o fuso gira, a rosca acompanha o fio do parafuso e o carro se movimenta para cima ou para baixo conforme a direção de rotação do fuso.

O resultado da subida ou descida do carro é a variação positiva ou negativa da posição angular dos braços, do detetor e do tubo. Como, por construção, os dois braços sempre sofrem a mesma variação angular, no mesmo sentido $(+\Delta \theta,-\Delta \theta)$, eles sempre estarão na mesma posição em relação à linha horizontal que passa pelo centro dos discos ( se inicialmente tiverem sido alinhados em $\theta=0^{\circ}$ ).

Quando os braços estão alinhados, o feixe de raios $X$ colimado cruza o eixo difratométrico (o eixo em torno do qual giram os discos). A amostra é posicionada tangenciando sua superfície neste ponto de cruzamento e alinhada ao longo do feixe.

Utilizamos um motor de 5 fases na configuração de 1000 passos por volta $\left(0.36^{\circ}\right.$ por passo). As características de torque do motor,

$\begin{array}{ll}\text { Max Torque Pull-out } & 95 \mathrm{~N} \mathrm{~cm} \\ \text { Holding Torque } & 110 \mathrm{~N} \mathrm{~cm} \\ \text { Torque Residual } & 11 \mathrm{~N} \mathrm{~cm}\end{array}$

mostraram-se bem adequadas.

Ao longo do projeto experimetamos uma fita de aço, com resistência à tração de 1200-1400 N/mm², em trés espessuras diferentes: 300,150 e 50 microns, todas com 14 millmetros de largura. A fita de 300 microns se mostrou muito rigida, interferindo na posição angular dos braços, principalmente do detetor. A fita de 50 microns possuia ótima flexibilidade e boa resisténcia à tração (ver Tabela 3.1). Porém, sua baixa resisténcia à ruptura perto das bordas, onde existem furações (Figura 3.4), tornou seu uso desaconselhável. 


\begin{tabular}{|ccc|}
\hline Fita & espessura & carga máxima \\
\hline 1 & 50 microns & $86-100 \mathrm{Kgf}$ \\
2 & 150 microns & $257-300 \mathrm{Kgf}$ \\
3 & 300 microns & $514-600 \mathrm{Kgf}$ \\
\hline
\end{tabular}

Tabela 3.1: especificação da fitas utilizadas no difratômetro. Resistência à tração das fitas: $1200-1400 \mathrm{~N} / \mathrm{mm}^{2}$

A fita de 150 microns foi escolhida como a mais adequada e a empregamos nos testes decritos no capitulo $\mathrm{V}$.

As fitas são furadas segundo o padrão mostrado na Figura 3.4 (a) e (b)

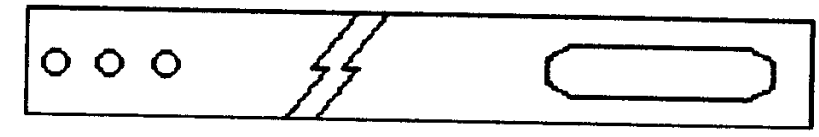

a) fita do tubo

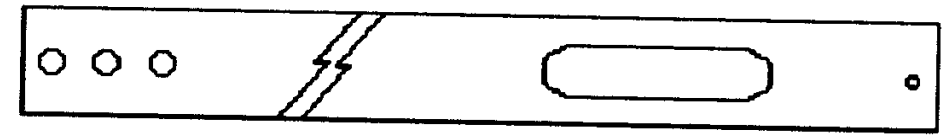

b) fita do detetor

Figura 3.4: furação das fitas utilizadas na movimentação dos braços do difratômetro

Os três furos da esquerda são para passagem de três parafusos que pressionam as fitas entre uma lâmina e a lateral do carro. O parafuso é rosqueado no carro e as fitas ficam rigidamente ligadas a ele.

Em cada disco foi feita uma rosca. Um parafuso passa pelo oblongo da fita 
pressionando-a entre o disco e uma presilha. Isto mantém as fitas rigidamente presas aos discos traseiros.

$\mathrm{Na}$ fita do detetor ainda existe mais um furo na extrema direita. Pelo mesmo processo de compressão a fita é agarrada por uma mandíbula da peça de alinhamento fino do detetor (descrita na letra (e) desta seção).

Na parte da frente do goniômetro estão dois braços. $O$ da fonte contendo: torre de raios $X$, soller e fendas; braço de deteção contendo: fenda, monocromador e detetor.

Idealmente o torque aplicado pelo peso da torre de raios $X$ sobre os discos é igual à componente vertical do peso da torre vezes a distância centro de gravidade da torre-centro do eixo do difratômetro. No caso em que a componente vertical do peso é igual ao próprio peso o torque aplicado é da ordem de $2000 \mathrm{~N} \cdot \mathrm{cm}$.

Este torque é compensado pelo torque aplicado pela fita ao mesmo disco. Assim, a fita fica sujeita a uma tração, transferida ao fuso axialmente. No caso real o torque necessário para girar o fuso depende desta força axial, do número de fios por unidade de comprimento do fuso e do coeficiente de atrito entre o fuso e a porca.

Utilizamos um motor capaz de um torque menor $(96 \mathrm{~N} \cdot \mathrm{cm})$ construindo um contrapeso para a torre. $O$ contrapeso foi instalado no disco de traz correspondente ao da torre, do lado oposto ao braço da torre. Figura 3.3a. Com isto podemos reduzir o peso efetivo da torre a valores adequados, que mantenham as fitas esticadas mas sem sobrecarregar 0 motor. Durante parte do experimento utilizamos o contrapeso diretamente sobre o carro. Figura 3.5b. 


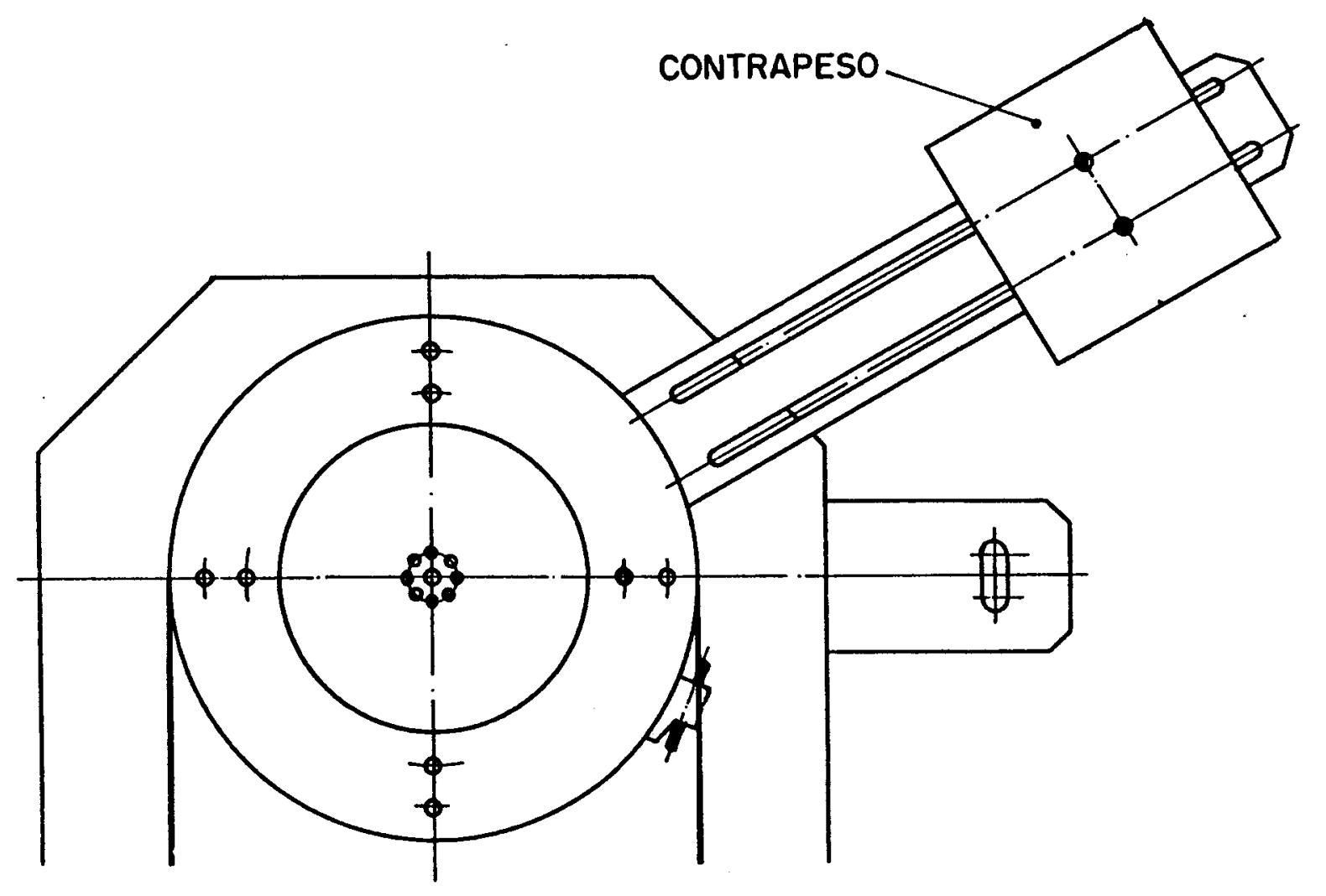

Figura 3.5a: esquema do contrapeso no disco de tras da torre

Para geradores de raios $X$ com cabos de alta-tensão pesados e pouco flexíveis, o cabo aumenta o peso sobre o carro. Para estes casos, além do contrapeso adequado, a base do goniômetro deve ser desenhada para permitir a livre movimentação do cabo em ângulos baixos.

O braço do detetor aplica um peso suportável $(\cong 10 \mathrm{~N})$ pelo motor utilizado, não necessitando de contrapeso. Além do detetor o braço de deteção serve de base para 0 monocromador, a fenda de recepção e fenda de espalhamento. 


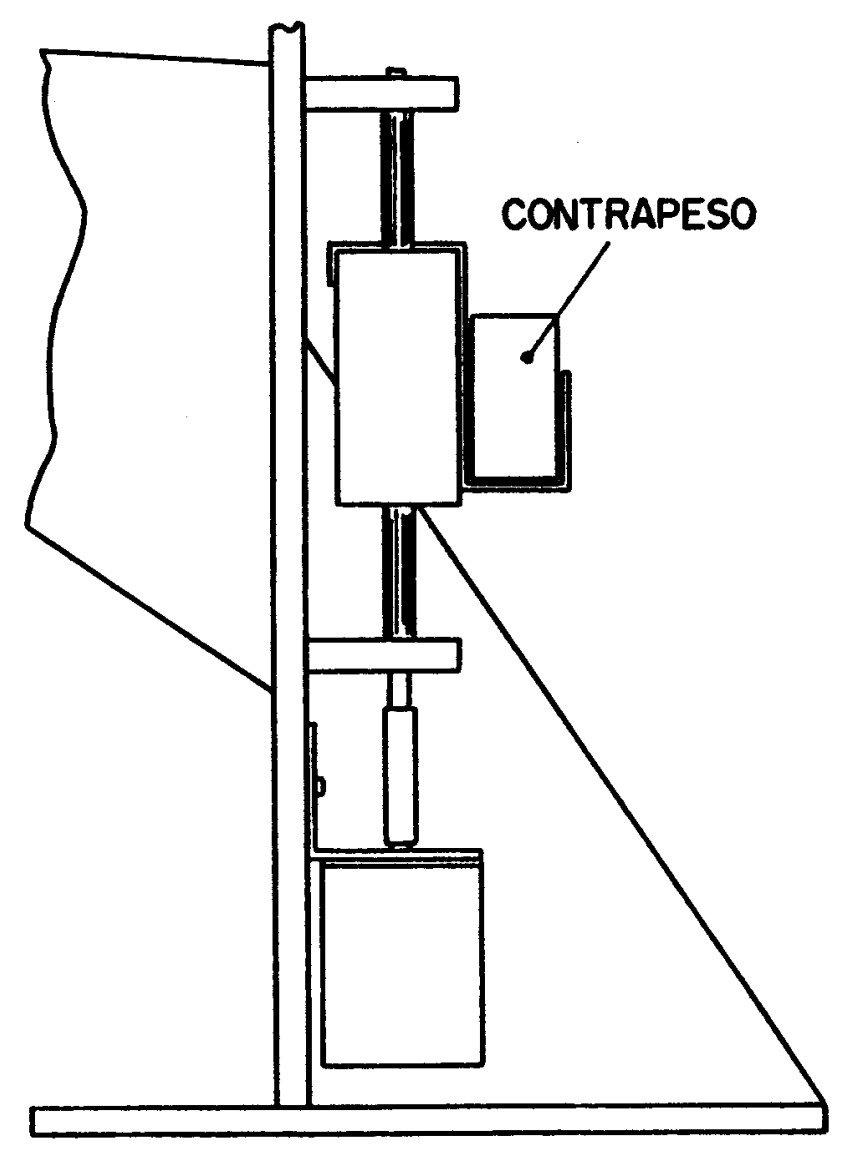

Figura 3.5b: esquema do contrapeso no carro

b) Caracteristicas de funcionamento

O deslocamento vertical do carro é produzido pelo fuso de 24 fios por polegada, acionado pelo motor de 1000 passos por revolução.

Uma translação $x$ do carro é transformada em rotações $+\theta$ e $-\theta$ dos discos, desde que possuam o mesmo raio $R$, através das fitas flex/veis.

A rotaçăo do motor, medida em número de passos $P$, está relacionada com a 
translação do carro $x$, medida em $\mathrm{mm}$, por:

$$
x=\frac{25.4}{24} \frac{P}{1000}
$$

O deslocamento angular $(\theta)$ pode agora facilmente ser escrito em função do número de passos,

$$
\theta=\frac{x}{R}=8.7271 \cdot 10^{-6} P(\mathrm{rad})=5.000 \cdot 10^{-4}(\text { graus }),
$$

onde o raio $(R)$ dos discos trazeiros é de $121.27 \mathrm{~mm}$.

Considerando agora a espessura da fita de aço, 150microns, podemos recalcular $\theta$ utilizando o raio efetivo correspondente ao raio do cilindro mais a metade da espessura da fita,

$$
\begin{gathered}
R_{e f}=121.27+0.08 \mathrm{~mm} \\
\theta=\frac{x}{R_{e f}}=4.99 \cdot 10^{-4} \text { graus }
\end{gathered}
$$

A variação angular máxima depende do deslocamento máximo do carro, estabelecido durante a construção do aparelho. Nesta fase foi deixada uma distáncia ao longo dos eixos do carro, de $206 \mathrm{~mm}$.

Como a altura do carro é de $100 \mathrm{~mm}$, sobram $106 \mathrm{~mm}$ para movimentação, que corresponde a $50^{\circ}$.

Resumimos as caracterlsticas do goniómetro na tabela 3.2. 


\begin{tabular}{|ll|}
\hline Geometria & Parafocalização ou \\
& Reflexão-Reflexão \\
Deslocamento linear máximo & \\
do carro & $106 \mathrm{~mm}$ \\
Raio discos trazeiros & $121.27 \mathrm{~mm}$ \\
Variação angular máxima & 50 graus \\
Variação angular minima & 0.0005 graus \\
Raio difratométrico & $170 \mathrm{~mm}$ \\
Velocidade máxima* & 350 passos / seg \\
\hline
\end{tabular}

*utilizando o SCOPE

Tabela 3.2: resumo das características do goniômetro

c) Montagem

Para o funcionamento adequado do goniômetro a instalação dos eixos do carro e dos rolamentos dos discos deve ser feita atentando para não se deixar folgas.

Os rolamentos entram sob pressão para evitar qualquer folga no mecanismo dos discos. Os eixos do carro devem ficar o mais espaçados possivel para tracionar - carro ao longo da sua largura. Com isto reduzimos a folga que pemitiria o carro ter um pequeno movimento de giro que tornaria desigual os ângulos dos dois braços. Também para evitar este jogo, o carro possui trés rolamentos, dois para um eixo e um para o outro eixo (Figura 3.6). 


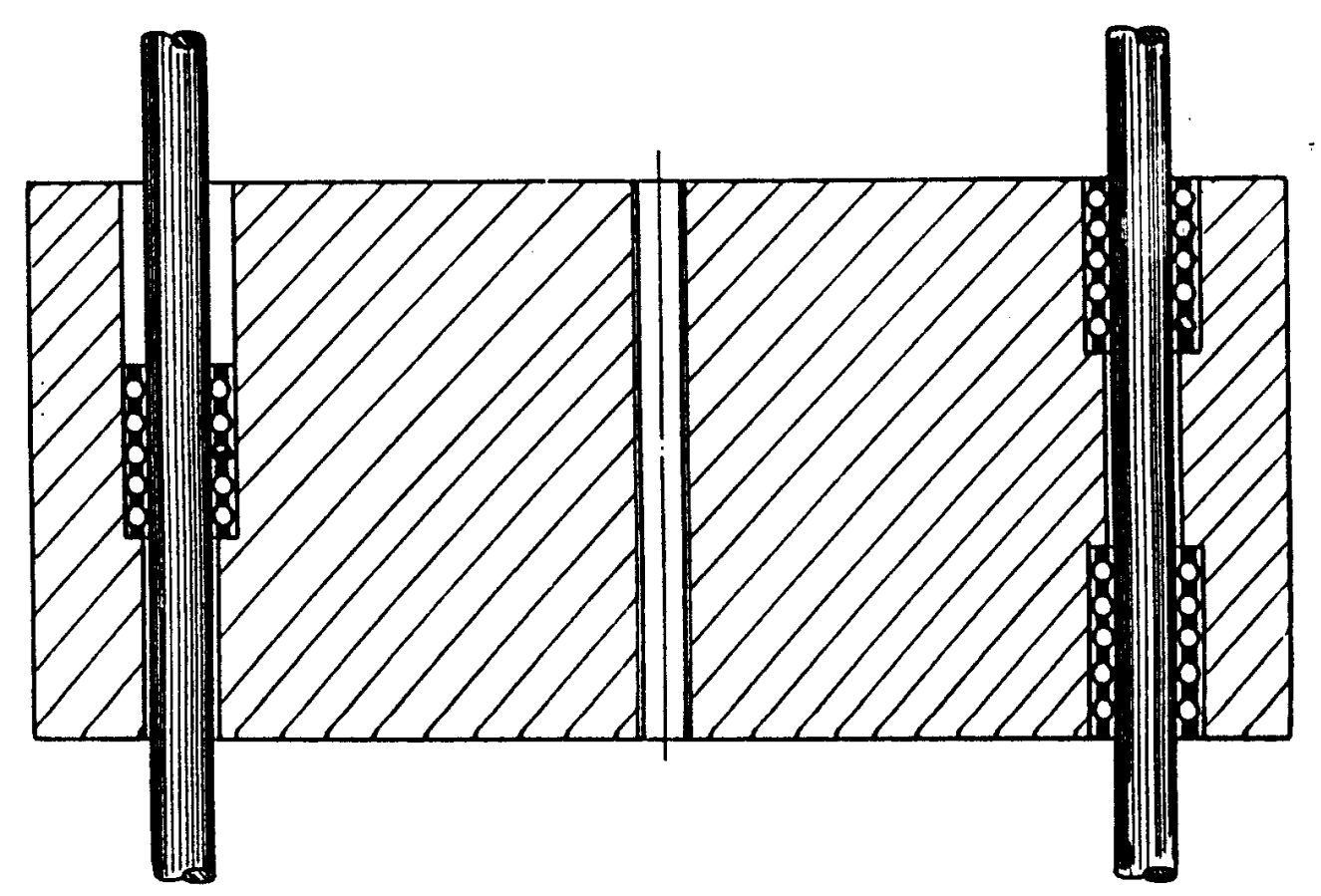

Figura 3.6: vista dos rolamentos internos do carro, ítem 8 da figura 3.1. 0 carro possui dimensões de $100 \times 242 \mathrm{~mm}$ com espaçamento entre eixos de $184 \mathrm{~mm}$.

\section{d) Manutenção}

Após a montagem, os cuidados com o aparelho se resumem em manter as fitas de aço e as bordas dos discos trazeiros livres de sujeira e protegidos da oxidação.

A sujeira ou a oxidação entre as fitas e os discos provocam uma alteração não controlada entre o passo do motor e a variação angular dos braços.

Outro cuidado na manutenção é manter o parafuso lubrificado para reduzir o desgaste por atrito com a rosca do carro.

e) Alinhamento

Para fazer o alinhamento fino do monocromador utilizamos um suporte elástico. O suporte elástico, feito de aço inox, permitia a movimentação em dois graus de liberdade: um de rotação para ajuste do ângulo de Bragg do moncromador e outro para tornar a superfície do cristal paralela ao eixo do difratômetro. 
Outro sistema projetado para facilitar o alinhamento óptico se localiza sobre o disco de traz concernente à movimentação do detetor. Uma peça tendo uma mandibula de um lado e uma garra do outro, segura a fita com a mandibula e é engatada à cabeça de um parafuso pela garra. O parafuso está apoiado no disco trazeiro do detetor.

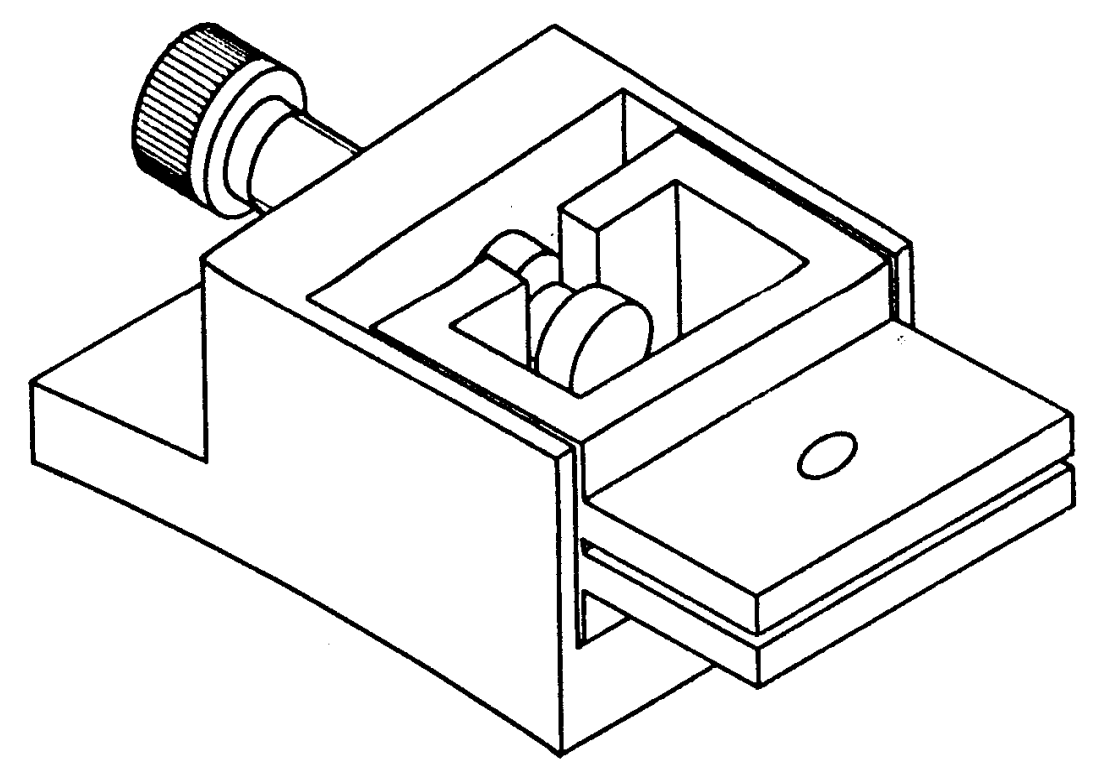

Figura 3.7: detalhe da peça de alinhamento do detetor, correspondente a um dos ítens 14 da figura 3.1, instalado no disco (cilindro) traseiro, responsável pela movimentação do braço de deteção. A parte móvel da peça agarra a fita de aço que tem seu comprimento efetivo ajustado pelo parafuso mostrado. A parte fixa é colocada na superfície do cilindro com raio de $121.27 \mathrm{~mm}$.

Girando o parafuso fazemos o disco girar e com ele o braço de deteção. 0 parafuso tem um curso de $10 \mathrm{~mm}$ o que equivale a uma variação de $4.7^{\circ}$ no braço do detetor. Feito $o$ alinhamento a presilha que fixa a fita nos cilindros pode ser novamente apertada.

O braço da fonte contém dois mecanismos de auxílio no alinhamento do tubo. O primeiro é um mancal cônico cujo eixo de rotação é paralelo ao eixo do difratômetro. Um parafuso libera ou fixa a torre na posição adequada. Este mecanismo é usado para fazer o feixe de raios $X$ passar pelo centro do difratômetro. 


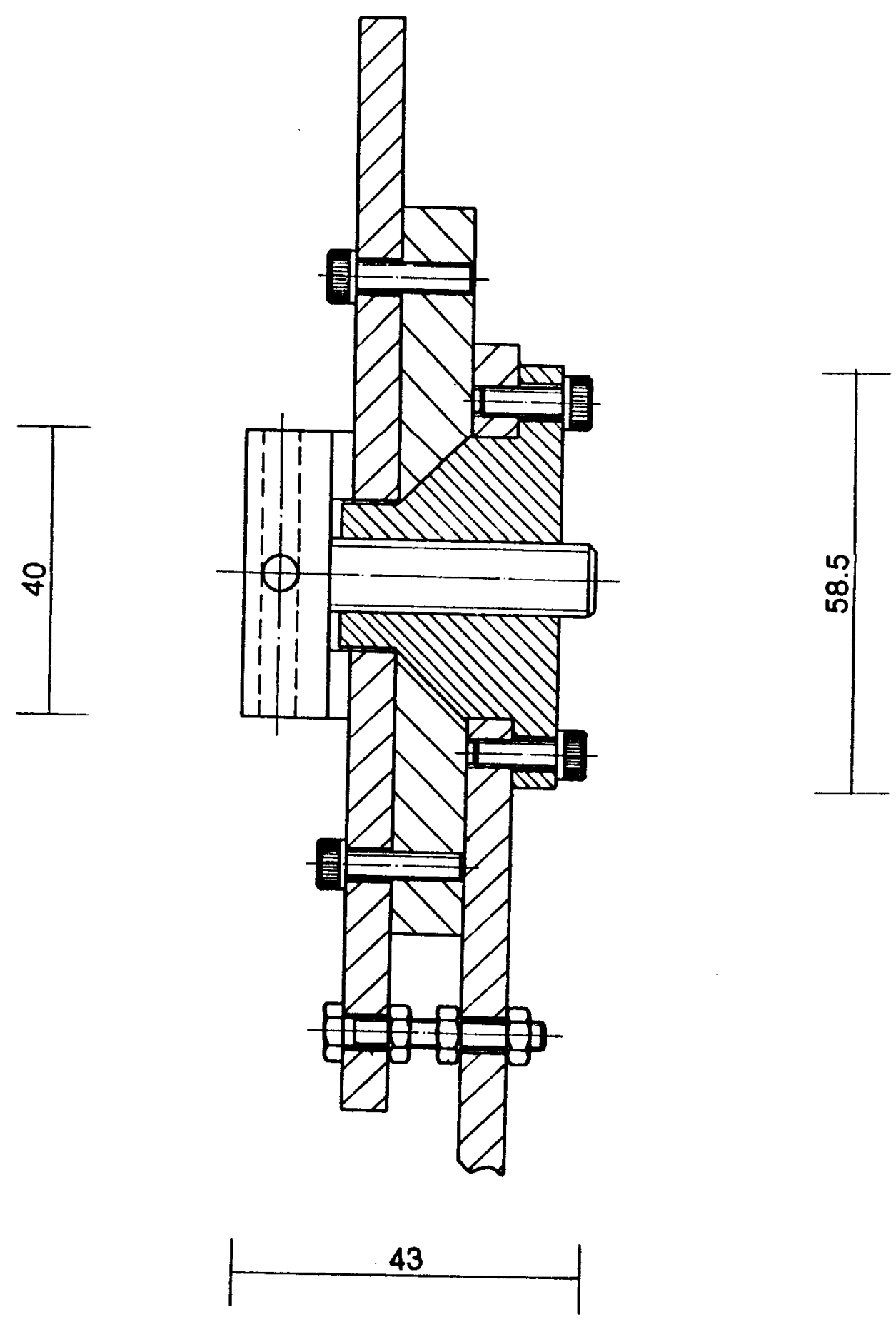

Figura 3.8: vista de perfil do mancal cônico e do sistema de alinhamento das fendas. Esta peça é instalada no braço da torre conforme mostrada no apêndice II. O mancal cônico permite que o suporte da fonte seja posicionado (girando num plano perpendicular do eixo do difratômetro) de forma a fazer o feixe passar pelo eixo do difratômetro. 
O segundo é um parafuso passante entre a chapa na qual a torre está fixa e a chapa que a suporta ( 0 braço propriamente dito). Três porcas servem para fixar o parafuso. Girando o parafuso fazemos as duas chapas se aproximarem ou afastarem. Este dispositivo permite ajustar o plano do alvo do tubo de raios $X$ paralelamente ao eixo do difratómetro (Figura 3.8).

f) Porta-amostra

Ao longo das medidas utilizamos dois porta-amostras. O porta-amostra inicialmente projetado era fixo na 'espinha" (chapa vertical) do goniômetro. Possuia um parafuso para ajuste de altura da amostra que ficava sobre uma mesa de alumínio. A mesa possuia dois rolamentos lineares para o movimento vertical. 0 parafuso empurrava a mesa para cima ou deixava-a descer quando desrosqueado.

Posteriormente passamos a utilizar um porta-amostra preso a base do goniômetro. Este novo modelo, além de permitir a regulagem de altura da amostra, como o anterior, permite o alinhamento de nivel em duas direções: paralela e perpendicular ao caminho ótico, graças a um sistema com três parafusos. Estes dois novos graus de liberdade tornaram possivel completar o alinhamento tuboamostra-detetor.

Nos dois casos as amostras policristalinas eram depositadas numa cubeta de vidro sobre a mesa.

Para as amostras líquidas foi construido um suporte especial sobre a mesa do porta-amostra. O suporte constituia-se de uma "capela" fechada para manter a atmosfera saturada e uma cubeta onde ficava a amostra, dentro da capela. Utilizamos cubetas de plástico, aço inox e vidro.

A "capela", feita a partir de um cano de PVC, é um semi-cilindro cujo eixo coincide com o do difratómetro. Sobre o cilindro foram abertas janelas de entrada e safda do feixe, vedadas com filme de poliéster. Esta geometria permite que os feixes de entrada e saída atravessem as respectivas janelas perpendicularmente ao filme de poliéster, independentemente do ângulo de difração, sempre sofrendo a mesma atenuação.

\section{III.2 Descriçăo Óptica}


A descrição óptica do goniômetro visa fornecer as condições de trabalho do aparelho, do ponto de vista da óptica de raios $X$. Ou seja, estaremos interessados nos conceitos de divergência, aceitância, largura de reflexão, foco, círculo de focalização, curvatura e raio difratométrico aplicados no nosso caso particular.

O difratômetro utiliza a geometria de parafocalização. Após os primeiros testes com cristais foi acrescentado um monocromador na geometria de reflexãoreflexão, necessário para os estudos de materiais amorfos..

O comprimento dos seus braços foi escolhido de maneira a formar um raio difratométrico de $170 \mathrm{~mm}$. Esta escolha influi na intensidade do feixe difratado e na resolução angular. A resolução angular aumenta com o raio difratométrico, e a intensidade do feixe diminui com o inverso do quadrado do raio.

Em todos os experimentos utilizamos um tubo selado de 1500 watts com alvo de cobre $\cdots$, foco de $0.04 \times 8 \mathrm{~mm}$, "take-off" angle de $6^{\circ}$, acionado por um gerador Kristaloflex da marca Siemens.

As fendas lineares e a fenda soller são fabricadas pela empresa Philips. As fendas são feitas a partir de dois cilindros de tântalo numa base de aço inoxidável. Empregamos fendas de 40, 80, 120, 440 e 880 microns.

Na tabela 3.3 mostramos a divergência obtida com cada fenda.

\begin{tabular}{|c|c|c|}
\hline Fenda $(\mathrm{mm})$ & \multicolumn{2}{|c|}{ Divergência } \\
\hline 0.04 & $0.00044 \mathrm{rad}$ & $0.03^{\circ}$ \\
\hline 0.08 & $0.00088 \mathrm{rad}$ & $0.05^{\circ}$ \\
\hline 0.12 & $0.0013 \mathrm{rad}$ & $0.08^{\circ}$ \\
\hline 0.44 & $0.0048 \mathrm{rad}$ & $0.28^{\circ}$ \\
\hline 0.88 & 0.01 & $0.56^{\circ}$ \\
\hline
\end{tabular}

Tabela 3.3: divergência para as fendas utilizadas nos experimentos 
A soller é construída com lâminas de aço inoxidável de $12 \times 8 \mathrm{~mm}$ de área. 0 espaçamento entre elas é de $0.52 \mathrm{~mm}$ formando uma pilha com $19 \mathrm{~mm}$ de altura.

O monocromador foi feito por nós seguindo a geometria de Johann. Curvamos um cristal de Sillcio cortado simetricamente na direção (111). Empregamos a técnica de mordedura entre duas superfícies cillndricas ( descrita com mais detalhes na seção II.2) com raio de $450 \mathrm{~mm}$, ou seja, raio de focalização de $225 \mathrm{~mm}$. Este raio foi escolhido por exigir um comprimento aceitável para o braço do difratómetro.

O cristal monocromador foi curvado ao longo do seu comprimento $(15 \mathrm{~mm}) \mathrm{e}$ instalado sobre o suporte elástico a $109 \mathrm{~mm}$ do ponto de focalização do feixe espalhado. O monocromador foi posicionado a $14.22^{\circ}$ do feixe incidente para refletir os planos (111).

A aceitância do cristal é calculada conforme mostrado na Figura 3.9. Para $\theta=$ $\theta_{\circ} \circ$ ângulo de incidência do feixe é igual ao ángulo de Bragg. Para $\theta \neq \theta_{0} \circ$ ángulo de incidência do feixe sobre o cristal é igual a $\beta$. O cristal refletirá o feixe incidente enquanto o desvio

$$
\delta=\theta-\beta
$$

for menor que a largura intrinseca do cristal (6.73" para Si111).

O cálculo de $\delta$ é feito a partir da relação

$$
\delta=\frac{d y}{d x}
$$

onde

$$
\left(x-x_{c}\right)^{2}+\left(y-y_{c}\right)^{2}=4 R^{2}
$$

é a equação do clrculo de curvatura e

$$
\begin{aligned}
& y_{c}=-R\left(1+\cos \left(2 \theta_{o}\right)\right) \\
& x_{c}=R \operatorname{sen}\left(2 \theta_{o}\right)
\end{aligned}
$$

são as coordenadas do centro do cfrculo. 
Resolvendo a equação acima para y em função de $x$ e fazendo a derivada podemos montar o grá́fico mostrado na Figura 3.10. Vemos nesta Figura 0 desvio em função do ângulo de incidência, de onde tiramos a aceitância do monocromador que utilizamos:

$$
\text { aceitância }=0.5^{\circ}
$$

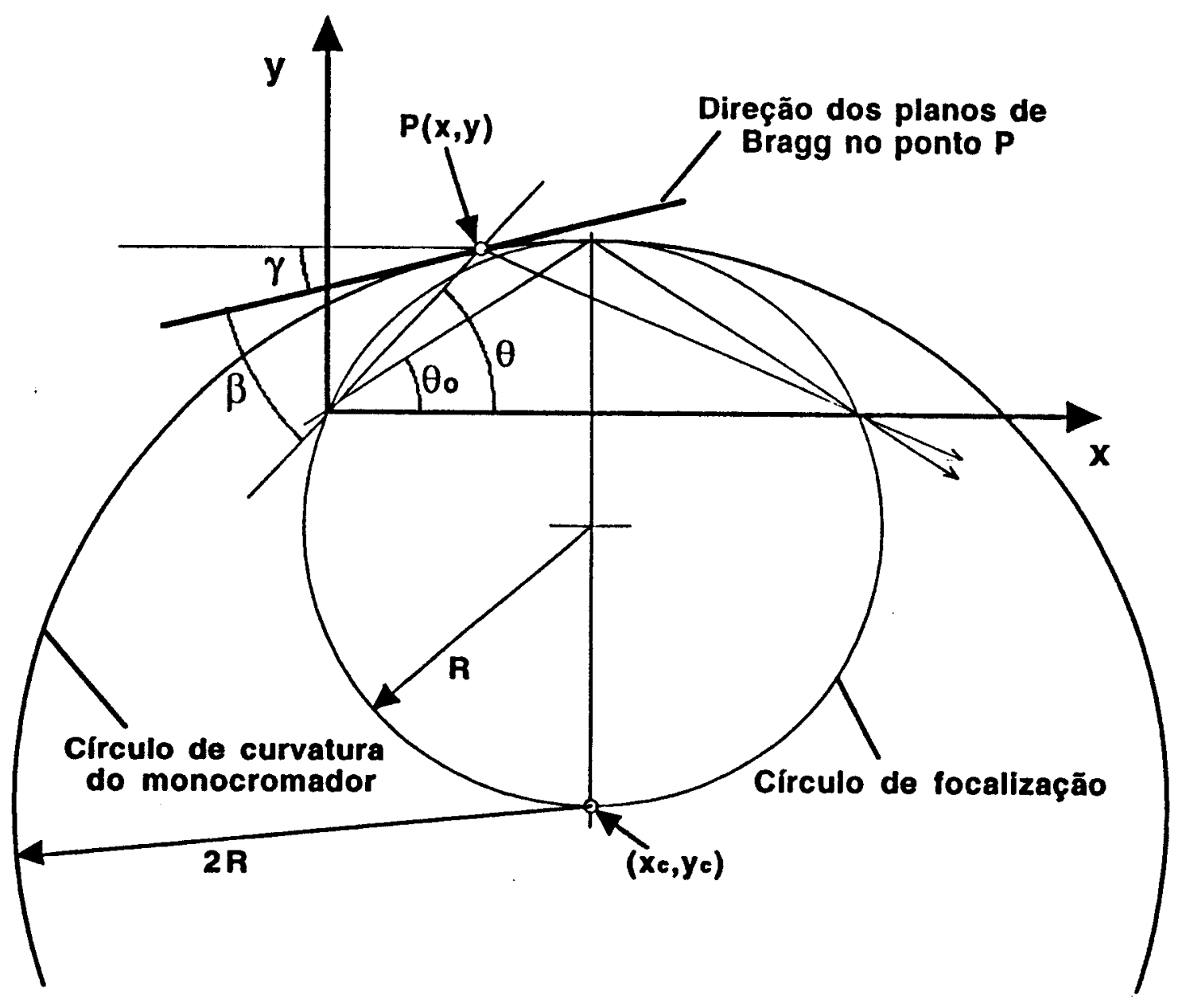

Figura 3.9: geometria usada no cálculo da aceitância 


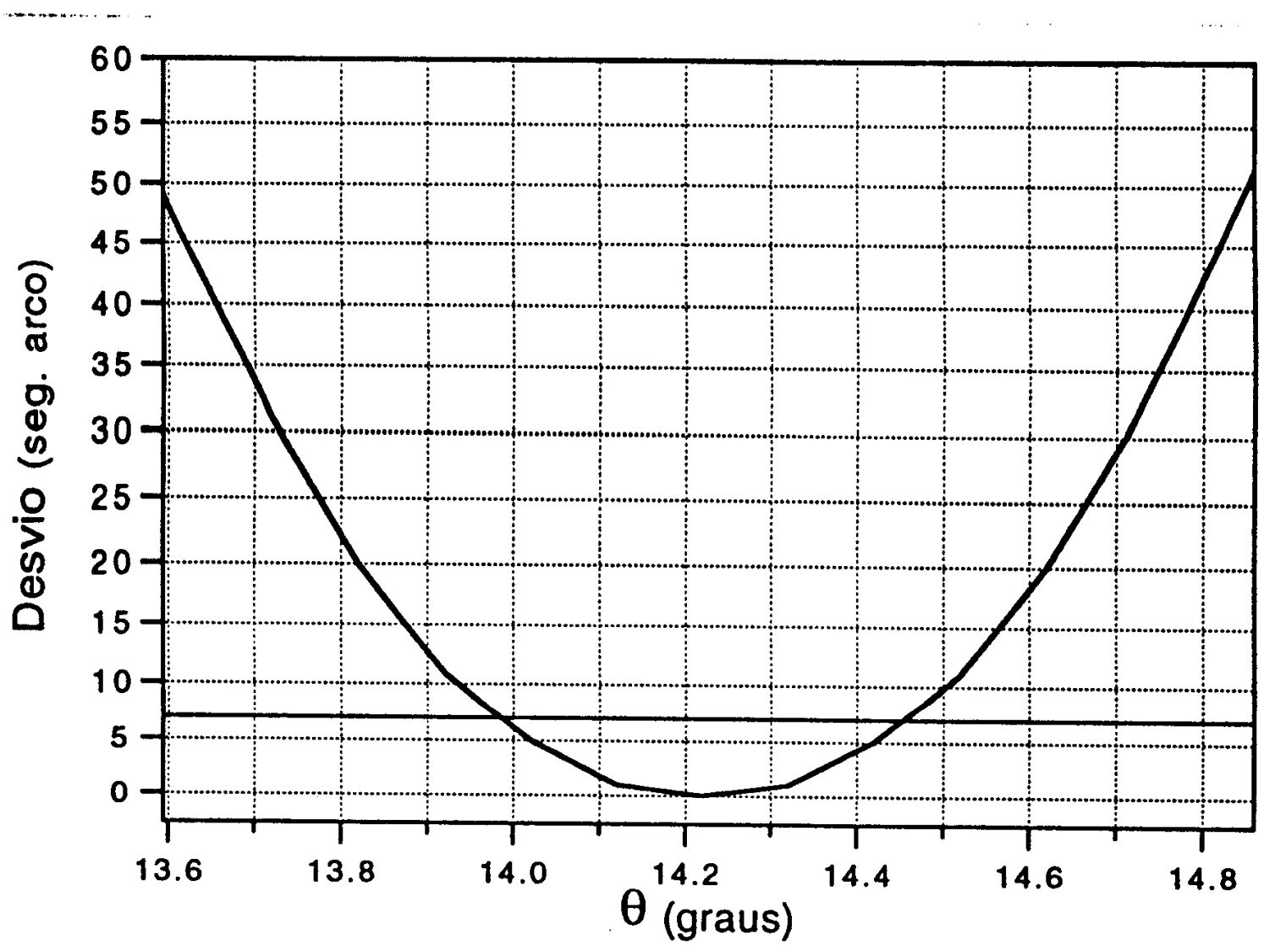

Figura 13.10: Curva da diferença entre o ângulo de incidência do feixe e o ângulo de Bragg, em função do ângulo de incidência. A linha reta corresponde a um desvio de 6.73" (largura intrínseca para este plano). Concluf́mos que a aceitância corresponde aos valores de $\theta$ que causam um desvio menor que 6.73".

\begin{tabular}{|ll|}
\hline Tipo & Johann \\
Raio de curvatura & $450 \mathrm{~mm}$ \\
Aceitancia & 0.5 graus* \\
\hline "para CuK $\alpha$ &
\end{tabular}

parâmetros do monocromador

Finalmente, utilizamos um detetor de cintilação com cristal de $\mathrm{Nal}(\mathrm{TI})$ localizado no ponto focal do monocromador. 


\section{III.3 Alinhamento}

Como vimos na descrição óptica o feixe de raios $X$ é gerado por um tubo selado, moldado por uma soller e uma fenda de divergência. Após refletir na amostra é filtrado por um monocromador e então medido por um detetor de cintilação. Todos esses elementos devem ser alinhados tomando-se como referência o eixo do difratômetro e o plano horizontal.

a) Condições de alinhamento

$O$ foco do tubo de raios $X$, visto a um ângulo de $6^{\circ} \mathrm{em}$ relação ao plano do alvo, possue as dimensões de $0.04 \times 0.8 \mathrm{~mm}^{2}$.

No alinhamento as lâminas da soller são postas perpendiculares ao eixo difratométrico. Sua função é limitar a divergência axial.

A fenda de divergência, sendo uma passagem no formato retangular, na posição perpendicular às lâminas da soller, limita a divergência radial. Esta fenda deve ser alinhada paralelamente ao foco.

Alinhadas a soller $e$ a fenda de divergência, em relação ao tubo ao qual estão fixas, o próximo passo é fazer o feixe passar pelo centro do difratômetro, ao longo do seu eixo.

A amostra deve ser alinhada com relação ao feixe. A zero graus a superfície do feixe deve estar paralela à superfície da amostra, tangenciando-a. Ou seja, o porta-amostra deve permitir um ajuste na altura (perpendicular ao feixe) e no plano da amostra, de modo a posiciona-la paralela ao feixe.

Quando usamos a geometria de parafocalização, o próximo passo é alinhar as duas fendas do braço do detetor com o foco. Da forma que projetamos a primeira destas fendas é a de espalhamento e a segunda de recepção. A mais estreita, de recepção, é colocada $10 \mathrm{~mm}$ atraz da fenda de espalhamento. Elas servem para reduzir o background, e devem estar paralelas à fenda de divergência.

$\mathrm{Na}$ geometria de relfexão-reflexão não foram usadas estas duas fendas. $\mathrm{O}$ monocromador foi colocado a $109 \mathrm{~mm}$ do foco (onde ficava a fenda de recepção). Esta distância foi calculada levando-se em conta que o círculo de focalização do 
cristal deve passar pelo foco do círculo de Rowland.

Para que haja difração pelo cristal o passo seguinte é ajustar o cristal no ângulo de Bragg. Além de cuidar que o feixe banhe o cristal e ajusta-lo no ângulo de Bragg, $O$ alinhamento deve fazer com que a projeção do feixe forme uma linha reta sobre o cristal. Sem este cuidado a intensidade observada será menor que a ideal, podendo chegar à extinção.

A geometria de parafocalização não exige que o detetor seja localizado em um ponto específico, podendo ficar logo após a fenda de recepção para evitar a eventual recepção de algum foton espalhado.

Na geometria de reflexão-reflexão o detetor deve ser posicionado sobre o círculo de focalização do monocromador, com uma tolerância igual à abertura de entrada do detetor.

b) Procedimento para alinhamento

Os passos para alinhamento nem sempre seguem numa sequência linear. Muitas vezes eles são iterativos e exigem do experimentador mais experiência do que técnica. Vamos descrever, de forma mais fiel possível, como procedemos no alinhamento da geometria de reflexão-reflexão. $O$ alinhamento na geometria de parafocalização segue o mesmo princípio.

Em primeiro lugar nivelamos o corpo do goniômetro e a mesa do portaamostra com um nivel de bolha.

Depois disto usamos o nível de bolha para posicionar os dois braços na posição horizontal.

O próximo passo é instalar a soller, a fenda de divergência o tubo de raios $X$ e o detetor no arranjo de Bragg-Brentano.

O passo seguinte é tornar a fenda de divergência paralela ao foco linha do tubo de raios $X$. Isto é feito girando $o^{\circ}$ conjunto soller/fenda de divergência de maneira a maximizar a intensidade do feixe difratado, devidamente filtrado com alumínio para evitar saturação.

Com uma fenda estreita (e.g. 50microns), fazer o feixe passar pelo centro do difratômetro. Para isto utilizamos os artifícios: 
1- deixar a entrada do detetor completamente aberta

2- instalar uma peça cônica cuja ponta coincide com o centro do difratômetro, instalada no seu eixo ôco.

3- utilizamos um fio de estanho fino para fazer sombra sobre o detetor e com isto localizar o feixe

Girando o tubo em torno do mancal cônico fazemos o feixe passar pelo centro do difratômetro com auxílio do fio de estanho.

No final do processo o detetor deve ser posicionado de forma a fazer o feixe passar pelo seu centro.

Adicionando uma fenda fina de recepção faz-se um ajuste fino na posição do detetor para fazer o alinhamento dos dois braços.

No final desta sequência o goniômetro dever apresentar um alinhamento, em $0^{\circ}$, melhor ou igual a $0.1^{\circ}$.

Para melhora-lo partimos para a medida com um padrão. Nos vários alinhamentos que fizemos usamos dois padrões. Um monocristal de silício cortado ao longo do plano 111 e um policristal também de Si fabricado pela empresa Philips.

Enviamos um comando para o motor executar 28000 passos $\left(14^{\%} / 0.0005^{\circ}\right)$. A partir deste ângulo, $\approx 14^{\circ}$, executamos uma varredura em torno do ângulo de Bragg para determinar a posição angular do pico Si111. Nesta posição o goniômetro pode ser calibrado usando o valor encontrado na literatura para a posição desta linha de difração.

O detetor pode ser transportado para sua posição final no círculo de focalização do monocromador. O monocromador $e$ instalado $e$ as fendas de recepção e espalhamento retiradas.

Mantendo a abertura do detetor completamente livre giramos devagar o ajuste elástico para encontrar a posição de Bragg do cristal monocromador. Iterativamente procuramos aumentar a intensidade fazendo com que a projeção do feixe sobre o cristal seja paralela ao eixo do cilindro formado pela curvatura do monocromador. Além disto, preferencialmente, fazemos esta projeção no meio do 
cristal.

No final destes passos o feixe deve entrar e sair do monocromador aproximadamente à mesma altura, indicando que a luz está incidindo no meio do cristal, onde ele mais se aproximada da curvatura cilíndrica ideal.

Deve-se observar finalmente que o feixe incida à meia altura no cristal do detetor. 
Capítulo IV

Acionamento do Difratômetro 
Neste capítulo descreveremos o sistema de controle, deteção e análise dos dados. Dividiremos 0 assunto em duas partes: hardware $\theta$ software. $O$ hardware inclui às eletrônicas de movimentação do goniômetro $\theta$ deteção, a interface de comunicação, controle $\Theta$ aquisição de dados. $O$ software trata dos programas de gerência do goniômetro.

A explanação seguirá uma sequência pragmática detalhando apenas os aspectos relevantes de utilização adequada do equipamento e à programação do protocolo de comunicação.

A cadeia utilizada é mostrada na Figura 4.1. Ela foi formada por dois sistemas distintos: o sistema SCOPE [RODRIGUES, 1991], desenvolvido pelo Grupo de Óptica de Raios X da UFPR e pelo sistema de espectroscopia nuclear da EG\&G ORTEC.

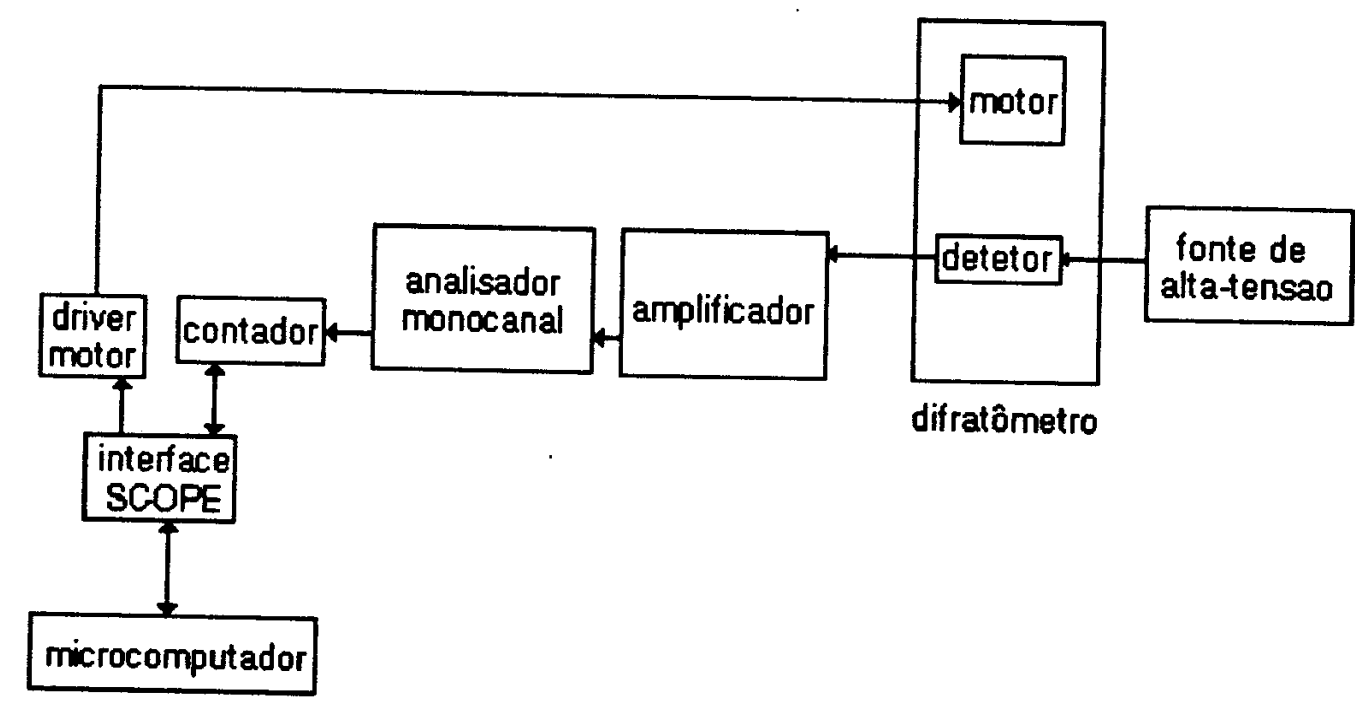

Figura 4.1: cadeia nuclear utilizada nas medidas com o difratômetro

Os módulos da EG\&G ORTEC utilizados foram: fonte de alta-tensão, detetor, amplificador e analisador monocanal. Os módulos do SCOPE foram: contador, interface de comunicação e driver do motor.

IV.1 Movimentação do Goniómetro, Controle e Processamento dos Sinais 
Os fotons espalhados pela amostra são detetados por um detetor de cintilação formado por um cristal de lodeto de Sódio dopado com Tálio, Nal(TI), e uma fotomultiplicadora

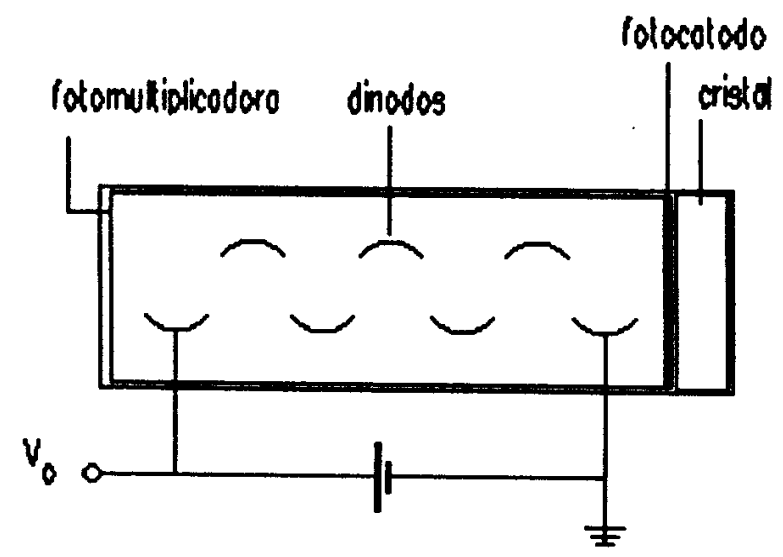

Figura 4.2: fotomultiplicadora usada nos detetores de cintilação

A fotomultiplicadora é alimentada por uma fonte de alta-tensão que aplica uma tensão em torno de 900 volts distribuídos entre os dinodos.

O sinal gerado na forma de pulsos contém duas informações. Sua freqüência média, isto é, o número de fotons por unidade de tempo e a amplitude do sinal corresponde à energia do foton incidente.

Este tipo de cirstal cintilador possui um eficiência máxima em torno de $50 \%$ $\left(\mathrm{N} / \mathrm{N}_{\mathrm{O}} \times 100, \mathrm{~N}\right.$-número de fotons emitidos pela fonte, $\mathrm{N}_{0}$-número de fotons que interagem com o cristal) [HARSHAW, 1978] para uma energia em torno de 10Kev e um comprimento de $37 \mathrm{~mm}$. Mesmo assim o detetor cintilador é largamente usado por seu baixo custo de aquisição e manutenção.

O sinal que sai do detetor é amplificado conforme a taxa de amplificação especificada pelo usuário. $O$ sinal de saída $\theta$ da ordem de volts. Geralmente as cadeias nucleares trabalham com tensão de zero a 10 volts. $O$ ganho e portanto a tensão de saída devem ser escolhidos em acordo com os parâmetros do monocanal.

$O$ analisador monocanal trabalha em dois modos. No modo discriminador todo sinal acima de uma tensão ajustável é considerado e enviado para o próximo 
elemento da cadeia. No modo "janela" os únicos sinais considerados válidos são aqueles cuja amplitude estão entre dois valores estabelecidos pelo usuário.

A janela é escolhida de modo a deixar passar os sinais correspondentes à região de interessse do espectro emitido pela fonte. A função da janela é portanto ajudar na monocromatização do feixe e consequentemente na redução do ruído.

Determinado o ganho do amplificador, escolhido de tal modo a maximizar a relação sinal/ruído, o monocanal ser deve colocado no modo janela, sendo esta escohida conforme o critério indicado no parágrafo anterior.

O monocanal tem uma saída normalmente indicada por "TTL". Por esta saída, os pulsos considerados válidos são transmitidos na forma retangular com amplitude de 5 volts (nível TTL).

Neste formato os pulsos são transmitidos para o contador que trata de contalos numa janela de tempo especificada no programa de gerenciamento do difratômetro. $O$ contador que utilizamos permitia dois modos de funcionamento, série e paralelo. Eles correspondem à forma de utilização de dois circuitos contadores. No modo parlelo cada circuito pode contar até um valor máximo de $65535\left(2^{16}\right)$. No modo série a contagem máxima é de $4,2948 \times 10^{9}\left(2^{32}\right)$. No final de cada intevalo de tempo o número de eventos contados é transmitido para a inteface que o envia para o micro-computador.

O usuário pode ordenar nova contagem numa posição. Neste caso o computador envia um comando de movimentação do motor através da Inteface SCOPE (IS).

O módulo do motor correspondente ao endereço contido no comando é acionado e executa o número de passos ordenados, posicionando o goniômetro na posição desejada.

\section{IV.2 Programas de Comunicação}

A interface tem a função de comunicação entre o sistema SCOPE e o microcomputador através de sua interface RS-232c (interface serial).

A conexão entre as duas iterfaces é mostrada na Figura 4.3 


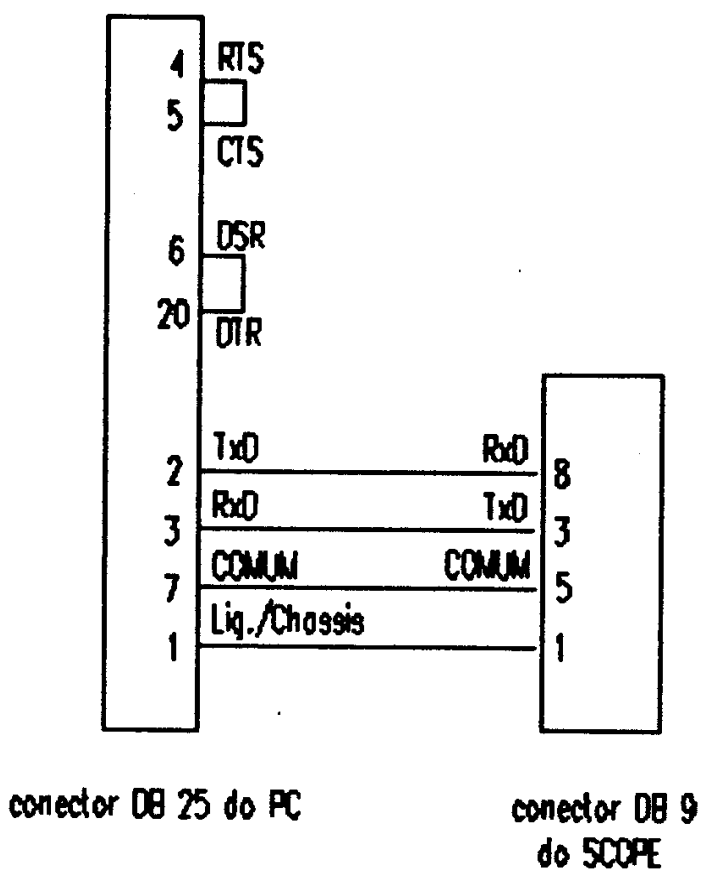

Figura 4.3: esquema da conexão PC - SCOPE

Normalmente o micro ativaria o pino 4 (RTS- Request to Send) perguntando se pode enviar dados. O SCOPE, quando pronto, ativaria o pino 5 (CTS- Clear to Send). Para reduzir o número de fios e simplificar o protocolo de comunicação os pinos 4 e 5 do micro foram interligados, liberando-o para comunicação sempre que necessário.

Os pinos 6 (DSR- Data Set Ready) e 20 (DTR- Data Terminal Ready) tem funções parecidas com os pinos 4 e 5 . Quando o transmissor acaba de enviar os dados, ele ativa o DSR indicando ao receptor que a transmissão acabou. Por sua vez o receptor deve responder ativando o DTR. Pelos mesmos motivos expostos acima os pinos 6 e 20 também foram interconectados.

Os pinos 2 (TXD-Transmited Data) e 3 (RxD- Received Data) são os responsáveis pela transmissão e recepção de dados, enquanto os pinos 4,5,6 e 20 tem um papel de controladores da comunicaçăo.

No pino 7 (Common) é aplicado um nível de tensão comum às duas interfaces e serve como referência para os sinais trocados por elas.

O pino 1 é um "Terra de carcaça" que serve de proteçáo para os dois hardwares contra sobre-corrente ou pulsos espúrios que poderiam danificar os 
equipamentos.

a) protocolo de comunicação

A ligação entre os pinos descrita quando tratamos da IS é o meio físico pelo qual a comunicação se dá, baseada em algumas regras agrupadas no protocolo de comunicação.

- protocolo é obedecido, por exemplo, quando desejamos obter um difratograma. Neste caso a sequência mais simples, sem considerar as várias situaçōes possíveis, é:

1- enviar comando de leitura do contador

2- ler mensagem do contador

3- enviar comando de movimentação do motor

4- repetir 1,2 e 3 até posição final.

O SCOPE foi programado para interpretar cinco comandos,

BIPE

CONTADOR

MULTI

MOTOR

DAC,

escritos em letra maiúsculas, obedecendo o código ASCII, seguidos de argumentos separados por vírgula. Para os comandos CONTADOR e MOTOR a "sintaxe" é a seguinte

$\begin{array}{ll}\text { CONTADOR, E, TC } & \text { (modo série) } \\ \text { CONTADOR,P,E,TC } & \text { (modo paralelo) } \\ \text { MOTOR,E,V,S,NP } & \end{array}$

onde as letras significam: 
E- endereço do módulo

TC- tempo de contagem

P- modo paralelo

V- velocidade em passos por segundo

S- sentido de rotação (H-horário ou A-antihorário)

NP- número de passos.

Durante as nossas medidas usamos os contadores com endereços 18 e 20 , no modo série.

Usamos também dois drivers para o motor, com endereços 0 e 2. Foram testadas velocidades de rotação entre 200 e 400 passos por segundo ( a velocidade máxima permitida pelo SCOPE é de 400 pps).

Depois de ajustado o contrapeso escolhemos trabalhar com 350pps, que mostrou ser adequada aos esforços solicitados.

Além dos comandos o SCOPE reconhece cinco caracteres de controle, mostrados na Tabela 4.1.

\begin{tabular}{|ccl|}
\hline $\begin{array}{c}\text { Caracter } \\
\text { de Controle }\end{array}$ & $\begin{array}{c}\text { Código } \\
\text { Decimal }\end{array}$ & \multicolumn{1}{c|}{ Função } \\
\hline X & 24 & reset \\
C & 03 & cancela tarefa \\
O & 15 & será envida mensagem de erro \\
M & 13 & final de comando \\
H & 08 & cancela último caracter \\
\hline
\end{tabular}

Tabela 4.1: caracteres de controle do SCOPE 
Com o conjunto de comandos, os caracteres de controle e o universo de caracteres válidos para comunicação dos dados, a linguagem de comunicação tem sua semântica constituída.

Duas regras formam a sintaxe:

1- Todo caracter deve ser ecoado

2- Supõe-se que um caracter de controle sempre é transmtido corretamente.

A segunda regra é baseada nos testes realizados em ambiente de laboratório onde "mais de 2 milhões de caracteres foram transmitidos sem erro" [INTERFACE, 1989].

Na EPROM do SCOPE o programa de comunicação está preparado para reconhecer 8 tipos de erro. Para cada um deles uma mensagem é enviada ao computador informando $\circ$ problema. As mensagems e sua explicação estão na Tabela 4.2 


\begin{tabular}{|c|c|}
\hline ARGUMENTO INVALIDO & $\begin{array}{l}\text { argumento com caracteres } \\
\text { diferentes da sua natureza }\end{array}$ \\
\hline CONSTANTE INVALIDA & $\begin{array}{l}\text { constante de tempo para o } \\
\text { contador está fora dos seus } \\
\text { limites }\end{array}$ \\
\hline $\begin{array}{l}\text { DAC MAIOR QUE } 255 \\
\text { DAC MAIOR QUE } 4095\end{array}$ & $\begin{array}{l}\text { atribuição de valores digitais excedeu o } \\
\text { limite de acordo com a capacidade do DAC }\end{array}$ \\
\hline ENDERECO INCOMPATIVEL & $\begin{array}{l}\text { endereço ultrapassou o limite ou, no caso } \\
\text { do motor e do contador, não é par }\end{array}$ \\
\hline ERRO DE SINTAXE & comando escrito de forma errada \\
\hline EXPOENTE IMPROPRIO & $\begin{array}{l}\text { expoente do número de passos do motor } \\
\text { ultrapassou o limite }\end{array}$ \\
\hline INSTRUÇÃO INEXISTENTE & $\begin{array}{l}\text { tentativa de realizar um comando } \\
\text { inexistente no SCOPE }\end{array}$ \\
\hline $\begin{array}{l}\text { VELOCIDADE NAO PERMITID, } \\
\text { SOBRECARGA }\end{array}$ & $\begin{array}{l}\text { velocidade ultrapassou o limite do motor } \\
\text { sobrecarga do multímetro }\end{array}$ \\
\hline
\end{tabular}

Tabela 4.2: mensagem e explicação dos erros detetados pelo SCOPE 
Mostramos a seguir o algoritmo para comunicação entre a interface SCOPE e o microcomputador através da sua interface serial RS-232c.

Separar comandos em caracteres

Enquando não for fim do comando

transmite caracter

espera eco

Se caracter de ida $\neq$ caracter do eco

transmite retrocesso (08)

espera eco

Fim Se

Fim Enquanto

Finaliza comando transmitindo LF (13)

espera eco

libera SCOPE transmitindo "branco" (32)

espera eco

Ler caracter

ecoa caracter

Se caracter $=15$

guardar os próximos caracteres como mensagem de erro

ativar flag de erro

Se caracter $=08$

eliminar último caracter recebido

Guardar caracter num string

Enquanto caracter $\neq 13$

Se flag de erro está ativado

mostrar mensagem de erro

Senão

mostrar resposta 
Finalmente damos a seguir os parâmetros de transmissāo na Tabela 4.3

\begin{tabular}{|lc|}
\hline taxa de modulação & 9600 baud \\
número de bits por caracter & 8 \\
número de bits de parada & 1 \\
paridade & sem paridade \\
\hline
\end{tabular}

Tabela 4.3: parâmetros de transmissão

b) Software desenvivido

Para os testes do goniómetro desenvolvemos dois programas: "Difrat" e "Rate", cujas listagens são apresentadas no apêndice.

O "Difrat" monitora a coleta de um difratograma a partir dos parâmetros fornecidos pelo usuário:

$$
\begin{aligned}
& \text { ângulo inicial } \\
& \text { ângulo final } \\
& \text { tempo de contagem } \\
& \text { passo, }
\end{aligned}
$$

armazenando os dados num arquivo com duas colunas, ângulo $\theta$ intensidade, separadas por um "tab".

O "Rate" foi usado nos alinhamentos, tanto dos braços como da altura da amostra. Executa seguidas contagens de fotons na posiçăo corrente do goniômetro. Suas saídas são sequenciais separadas por "tab". Para executar este programa é necessário apenas fornecer a base de tempo para contagem. 0 acionamento de qualquer tecla finaliza o programa. 


\section{Capítulo V}

Testes de Caracterização Pealiz dos com o Difratômetro 
Neste capítulo vamos tratar da caracterização do goniômetro proposto. Faremos um relato $\theta$ mostraremos os resultados dos experimentos realizados visando determinar seus parâmetros de funcionabilidade. Acrescentaremos detalhes sobre alguns tópicos ou fases que foram relevantes para o desenrolar do trabalho.

\section{V.1 Caracterização}

A caracterizaçăo do difratômetro determina as condiçōes de funcionamento do aparelho, sob dois aspectos:

(i) dimensionamento das peças

(ii) características de funcionamento

O ítem "dimensionamento das peças" neste trabalho se refere à escolha adequada das fitas de aço e do contrapeso.

No ítem "caracteristicas de funcionamento" estamos interessados em:

(i) determinar a correspondência entre 1 passo do motor e o correspondente incremento angular resultante.

(ii) verificar sua reprodutibilidade tanto para deslocamentos de ida e volta como para deslocamentos em apenas uma direção.

A reprodutibilidade depende da histerese do sistema. A cada vez que se reverte a rotação do motor, as "folgas" do sistema mecânico fazem com que a resposta angular se atrase em relação à posiçăo, em número de passos, do motor (Figura 5.1). 


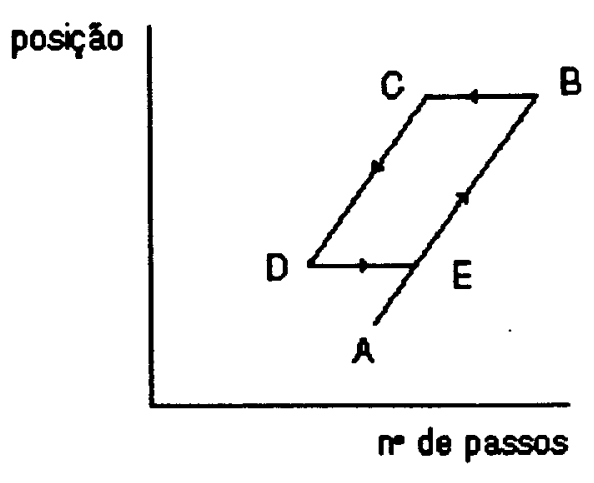

Figura 5.1: histerese para um sistema mecânico onde a posição depende do número de passos realizados (por um motor, por exemplo).

Para a calibração do passo foram utilizados dois métodos: (1) medidas através de um auto colimador, improvisado a partir de um teodolito e (2) medidas da separação angular de picos de difração do silício.

a) Calibração do passo pelo Teodolito

Com esta perspectiva em mente inicialmente tentamos fazer uma calibração do goniômetro com um teodolito no modo de auto colimação (Figura 5.2). Tínhamos a intenção de medir o passo angular correspondente a 1 passo do motor.

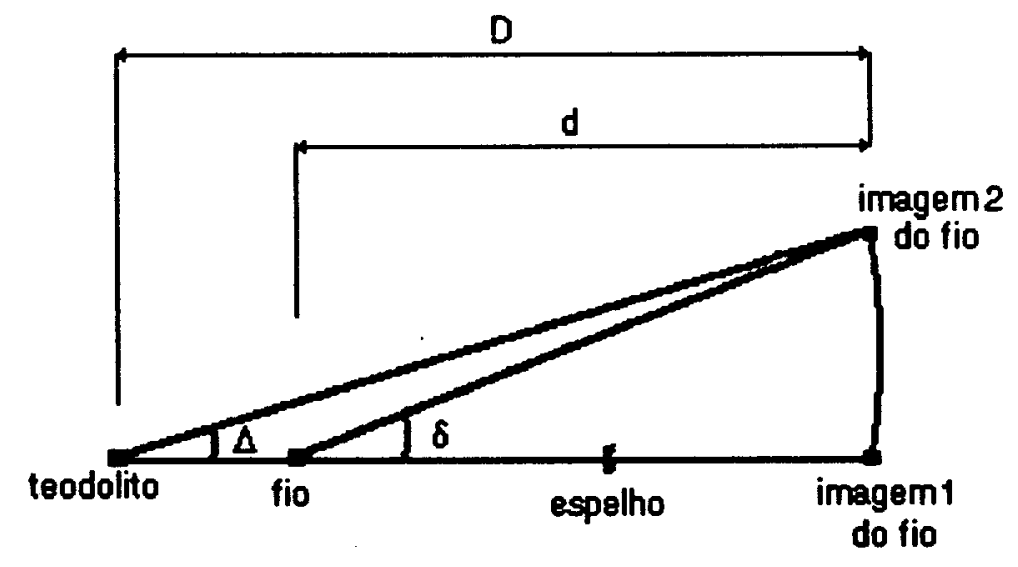

Figura 5.2: diagrama de funcionamento do teodolito no modo de autocolimação. Após uma rotação do espelho produz a imgem 2 do fio.

Utilizamos um teodolito TH-20D, da Pentax com graduação de 10". Colamos um espelho em um dos braços do goniômetro. Posicionamos o teodolito a 
$2.5 \mathrm{~m}$. A $11.7 \mathrm{~cm}$ do seu centro esticamos um fio de cobre esmaltado $\mathrm{n}^{2} 28$. 0 teodolito era focalizado na imagem do fio produzida pelo espelho e o ángulo de visada vertical era registrado. O motor era acionado de um certo número de passos (entre 200 e 1800) e a nova posicão da imagem era registrada.

Referindo-se à geometria apresentada na Figura 5.2, o deslocamento angular do espelho é dado pelo ángulo $\delta$ e a medida fornecida pelo teodolito $e \dot{\Delta}$. Em primeira ordem, a relação entre estes valores é dada por:

$$
\delta \cong \frac{D}{d} \Delta
$$

Através deste método foi determinada a seguinte relação entre passos do motor e incremento angular do difratômetro:

$$
\Delta \theta=(5.02 \pm 0.02) \times 10^{-4} \text { graus/passo. }
$$

b) Medidas difratométricas com um monocristal de Silício

Os valores que vamos apresentar a seguir se referem às medidas de calibração feitas com um monocristal de Si111 entre as difraçōes relativas aos planos (111) e (333). Para tanto utilizamos um um parâmetro de rede de 5.4307 Angstrons [PARRISH, 1965].

Inicialmente alinhamos o goniômetro. A partir desta posição $\left(0^{\circ}\right)$, utilizando o programa de controle para fazer o motor deslocar de 28000 passos. Considerando a relação de 0.0005 graus/passo, o deslocamento de 28000 passos colocaria o goniômetro em $14^{\circ}$. A partir dai repetimos 10 vezes o seguinte procedimento: 
1- coletar um difratograma de 331 pontos executando 2 passos $\left(\sim 0.001^{\circ}\right)$ entre pontos e contando 1 segundo em cada medida.

2- executar 65700 passos (parando em $47.25^{\circ}$ aproximadamente)

3- coletar um difratograma de 500 pontos executando 2 passos entre cada ponto e 2 segundos em cada medida (parando em $\sim 47.75^{\circ}$ ).

4- repetir o item 3 no sentido contrário, terminando o difratograma em -47.25 graus.

5- executar 65700 passos (parando em $-14.4^{\circ}$ ).

6- repetir o item 1 no sentido descendente $\left(14.4^{\circ}-14.07^{\circ}\right)$.

As condiçōes de operação foram: soller, fenda de divergência de 80 microns e monocromador. Nas medidas no plano (111) utilizamos $40 \mathrm{Kv}, 10 \mathrm{~mA}$ e nas do (333) 40Kv, 30mA.

Para cada difratograma fizemos um ajuste da metade superior de cada pico por uma gaussiana,

$$
A e^{-(x-B)^{2} / C}
$$

O valor de "B" fornece a posição experimental do pico em número de passos e a literatura fornece o ângulo esperado de cada pico (e.g. [KLUG, 1974]) .

i) Calibração do passo por difratometria

Dividindo o ângulo entre 2 picos pelo número de passos correspondentes, obtemos o deslocamento angular por passo.

Na Tabela 5.1 discriminamos os dados correspondentes às medidas feitas na direção de ângulo crescente (ida) $\Theta$ ângulo descrescente (volta). 


\begin{tabular}{|c|ccccc|}
\cline { 2 - 5 } \multicolumn{1}{c|}{} & \multicolumn{4}{c|}{ Posição dos picos em passos } \\
\hline ida (1) & $333 \alpha_{1}$ & $333 \alpha_{2}$ & $111 \alpha$ & $\begin{array}{l}333 \alpha_{1}- \\
111 \alpha\end{array}$ & $\begin{array}{l}\text { Passo } \\
\text { volta }(-1)\end{array}$ \\
\end{tabular}

\begin{tabular}{|llllll|}
\hline-1 & 94917.8 & 95254.6 & 28393.8 & 66524 & 4.99671 \\
-1 & 94911.4 & 95248.8 & 28393.2 & 66518.2 & 4.99714 \\
-1 & 94912.2 & 95250.4 & 28384.4 & 66527.8 & 4.99642 \\
-1 & 94913.4 & 95255.6 & 28397.2 & 66516.2 & 4.99729 \\
-1 & 94920 & 95257.8 & 28398 & 66522 & 4.99686 \\
\hline
\end{tabular}

Médias:

\begin{tabular}{|ccccc|}
\hline 94915.0 & 95253.4 & 28393.3 & 66521.6 & 4.99689 \\
\pm 3.3 & \pm 3.8 & \pm 4.8 & \pm 4.1 & \pm 0.0003 \\
\hline
\end{tabular}

\begin{tabular}{|lccccc|}
\hline 1 & 94959.6 & 95278.2 & 28432.2 & 66527.4 & 4.99645 \\
1 & 94954.8 & 95278.8 & 28427.6 & 66527.2 & 4.99647 \\
1 & 94955.6 & 95284.8 & 28417.4 & 66538.2 & 4.99564 \\
1 & 94962 & 95287 & 28428.8 & 66533.2 & 4.99602 \\
1 & 94960.4 & 95286.8 & 28436.6 & 66523.8 & 4.99672 \\
\hline Médias: & & & & & \\
\cline { 2 - 6 } & 94958.5 & 95286.8 & 28428.5 & 66530.0 & 4.99626 \\
& \pm 2.8 & \pm 3.8 & \pm 6.3 & \pm 5.0 & \pm 0.0004 \\
\hline
\end{tabular}

Tabela 5.1: localização, em número de passos dos picos das reflexōes Si333 e Si111, para as linhas CuK $\alpha_{1,2}$ 
Na Tabela 5.2 usamos a média das 10 medidas feitas usando a diferença, em número de passos entre $333 \alpha_{1}$ e $111 \alpha$, para calcular a média geral do fator de calibração, pelo método difratométrico: $(0.49965 \pm 0.00005) \times 10^{-3}$ graus.

\begin{tabular}{|ll|}
\hline $\begin{array}{l}\text { Média Geral (passos) } \\
\text { Desvio Padrāo (passos) }\end{array}$ & 66525.8 \\
$\begin{array}{l}\text { Fator de Calibração } \\
\text { (graus/passo) }\end{array}$ & 6.23 \\
$\begin{array}{l}\text { Desvio } \\
\text { (Graus/passo) }\end{array}$ & $4.9965 \times 10^{-4}$ \\
\hline
\end{tabular}

Tabela 5.2: dados experimentais de calibração do passo obtidos por difração de raios $X$ numa amostra monocristalina de Silício .

ii) Histerese

Calculamos a histerese para os 3 picos, $333 \alpha_{1}, 333 \alpha_{2}, 111 \alpha$ subtraindo os valores para $\theta$ crescente $\theta \theta$ decrescente (Tabela 5.2).

\begin{tabular}{|lll|}
\hline $333 \alpha_{1}$ & $333 \alpha_{2}$ & $111 \alpha$ \\
\hline 41.8 & 23.6 & 38.4 \\
43.4 & 30.0 & 34.4 \\
43.3 & 34.4 & 33.0 \\
48.6 & 31.4 & 31.6 \\
40.4 & 29.0 & 38.6 \\
\hline
\end{tabular}

Tabela 5.3: histerese, em passos, correspondente à posição de cada pico. 
Estes valores foram obtidos a partir da Tabela 5.1 subtraindo os valores por linha (ida menos volta) para cada pico.

Mostramos na Tabela 5.4 os valores médios da Tabela 5.3 e calculamos a histerese em graus.

\begin{tabular}{|lcl|}
\hline pico & $\begin{array}{l}\text { histerese em } \\
\text { passos }\end{array}$ & $\begin{array}{l}\text { histerese em } \\
\text { graus }\end{array}$ \\
\hline $333 \alpha_{1}$ & 43.4 & $2.2 \times 10^{-2}$ \\
$333 \alpha_{2}$ & 29.68 & $1.5 \times 10^{-2}$ \\
$111 \alpha$ & 35.2 & $1.7 \times 10^{-2}$ \\
\hline
\end{tabular}

Tabela 5.4: histerese medida em cada um dos picos. Os valores em graus foram obtidos multiplicando o número de passos por $0.4997 \times 10^{-3}$ (calibração do passo obtido por difratometria)

iii) Reprodutibilidade em uma direção

A partir da Tabela 5.1 podemos obter a reprodutibilidade do sistema mecânico no posicionamento angular.. A Tabela 5.4 mostra os valores médios para a posição dos picos da Tabela 5.1, tanto na "ida" quanto na "volta".

\begin{tabular}{|cccc|}
\hline ida/volta & $333 \alpha_{1}$ & $333 \alpha_{2}$ & $111 \alpha$ \\
\hline ida & $94915.0 \pm 3.3$ & $95253.4 \pm 3.8$ & $28393.3 \pm 4.8$ \\
volta & $94958.5 \pm 2.8$ & $95286.8 \pm 3.8$ & $28428.5 \pm 6.3$ \\
\hline
\end{tabular}

Tabela 5.5: posição média dos picos da Tabela 5.1, em passos, determinados em cinco varreduras de "ida" e cinco de "volta".

Estes dados mostram que a determinação do pico Si111 $\alpha$ foi mais imprecisa 


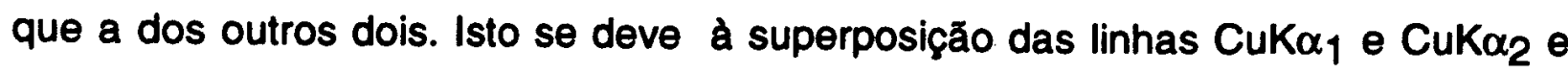
pode ser melhorada aumentando o tempo de contagem.

Vemos também uma ligeira assimetria quanto à reprodutibilidade do mecanismo na ida ( \pm 3.9 passos, i.e., 0.0019 graus) e na volta ( \pm 4 .3passos, i.e., 0.0021 graus). Ela pode ser explicada pela assimetria do mecanismo quanto ao esforço exigido do motor e à torção no sistema de ligação entre o eixo do motor e o fuso. Estes resultados, porém, não são conclusivos por uma pequena amostragem pequena (3 picos).

Considerando os valores relativos aos picos $333 \alpha_{1}$ e $333 \alpha_{2}$, os dados da Tabela 5.4 demonstram que o mecanismo reproduz os picos dentro de \pm 3.4 passos ou \pm 0.0017 graus. Considerando também o pico $111 \alpha$ a reprodutibilidade é de \pm 4.1passos ou \pm 0.0020 graus.

\section{V.2 Observações feitas ao longo dos experimentos}

Neste item vamos relatar algumas observações feitas ao longo das medidas. Apesar de não ser um suporte para a caracterização do aparelho, a descrição a seguir dará uma idéia de como os experimentos foram conduzidos.

$\mathrm{Na}$ caracterização ou demonstração de funcionamento do goniômetro utilizamos três tipos de amostra: policristalina, monocristal e solução.

As primeiras montagens utilizando a geometria de parafocalização foram feitas seguindo o procedimento descrito na seção III.3 (Alinhamento) sem apresentar dificuldades, com uma amostra policristalina de Silício.

Verificado o funcionamento adequado do goniômetro nestas condições, mudamos para a geometria de reflexão-reflexão, i.é, utilizando-se de um monocromador.

\section{a) Monocromador}

Para isto projetamos um monocromador de Johann cujo raio de curvatura foi escolhido para manter as dimensões do caminho óptico nem muito grandes (que aumentaria o torque, a atenuação do feixe pelo ar, etc.), nem muito pequeno (limitado pelo risco de quebrar o cristal).

Na construção do corpo do monocromador tentamos três técnicas. 
Na primeira o bloco de alumínio foi fresado em degraus, depois lixado para suavizar a superfície até coincidir com um molde. $O$ molde foi um semicírculo sobre papel vegetal com raio igual ao desejado.

Montamos o goniômetro com o monocromador assim obtido. Refizemos as medidas com o policristal tentando melhorar o alinhamento.

A intensidade do feixe difratado, porém, era muito mais baixa do que esperado (aproximadamente uma ordem de grandeza).

Suspeitamos da inadequação do método de construção que poderia ter deixado alguma irregularidade na superfície ou mesmo ter produzido um raio de curvatura diferente do especificado $(450 \mathrm{~mm})$.

Por este motivo tentamos fabricar um monocromador colando as bordas do cristal sobre duas bases que por sua vez foram fixas sobre as bordas de uma lâmina de aço (Figura 5.3).

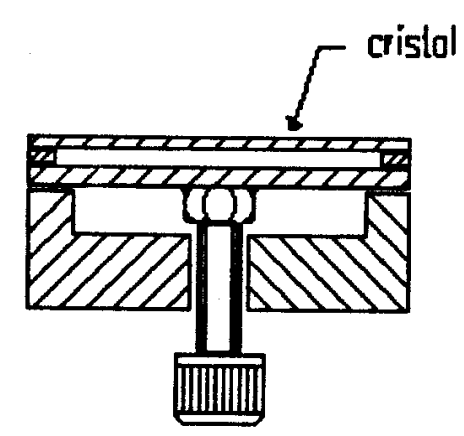

Figura 5.3: monocromador feito com cola

Atrás desta lâmina colamos uma porca. Com um suporte adequado, girando um parafuso curvamos a lâmina e consequentemente $o$ cristal. Esta montagem não funcionou porque a cola usada entre o cristal $\theta$ as duas bases cedeu.

Voltamos a lâmina à posição plana e preenchemos de cola o espaço entre a lâmina e 0 cristal.

O desempenho desta montagem não foi perceptivelmente melhor que o da primeira, obtendo-se a mesma relação de intensidades obtidas originalmente. 
Esta montagem foi abandonada porque o cristal partiu numa das tentativas de ajustar o raio de curvatura.

A terceira técnica tentada seguiu o mesmo projeto da primeira, diferindo apenas na sua execução. Desta feita a superfície cilíndrica foi fabricada com auxílio de uma fresadora e uma mesa divisora onde o bloco de alumínio foi colocado a uma distância do centro correspondente ao raio de curvatura. Girando a mesa divisora a fresa usinava o alumínio no formato desejado. Esta foi a montagem utilizada na caracterização do goniômetro.

Durante $\mathrm{o}$ alinhamento observamos uma queda sensivel de intensidade, da ordem de dez vezes, da geometria que utiliza monocromador (Reflexão-Reflexão) comparativamente à geometria de Parafocalização. Notamos também a alta sensibilidade da intensidade com o alinhamento da amostra, onde pequenas mudanças de posição faziam a intensidade cair em mais dez vezes.

A op̧̧ão adotada para o prosseguimento imediato das medidas foi trocar a amostra policristalina pelo monocristal que possui uma refletividade próxima de $100 \%$. Com isto aumentamos a intensidade e controlamos melhor $o$ alinhamento.

b) Amostra líquida

Em relação ao líquido todas as medidas foram feitas com monocromador. Nestes casos, porém, não tivemos problemas de alinhamento da amostra, que devido à gravidade sempre mantinha sua superfície paralela ao eixo óptico.

Por ação da tensão superficial o volume do líquido retido no recipiente pode ser maior que o próprio volume do recipiente. Tal comportamento auxilia no ajuste da altura da amostra. Da mesma forma que para os sólidos, encontramos a posição correta da solução na meia-intensidade do feixe com o goniômetro a zero grau.

Para dar uma idéia da precisão obtida com este método, um feixe com altura de $0.2 \mathrm{~mm}$ e uma contagem de $5000 \mathrm{cps}$, a meia intensidade fornece uma contagem de $(2500 \pm 150) \operatorname{cps}(150=3 \sigma)$. Portanto 0 erro na determinação da altura é da ordem de $\pm 0.01 \mathrm{~mm}$.

Durante as medidas longas com líquidos observamos o efeito da evaporação do líquido na intensidade do feixe difratado. Além deste efeito a evaporação do solvente de uma solução causa um aumento de concentração que muda as condições de trabalho. 
Para evitar este problema construímos um porta-amostra fechado, de tal forma que após a saturação do meio, o volume do líquido não seria alterado.

c) Relação Sinal / Ruído

A relação sinal ruído é o quociente entre o sinal devido somente à radiação difratada pela amostra e o sinal causado por outros efeitos, entre eles o efeito Compton, espalhamento pelo ar, ruído eletrônico, etc.

Nas medidas feitas utilizamos dois artifícios para otimizar esta relação. Reduzimos o tamanho das fendas $\theta$ instalamos um monocromador (sem fendas de recepção e espalhamento).

As fendas disponíveis tinham abertura entre 0.04 a $0.88 \mathrm{~mm}$.

O monocromador apesar de reduzir em uma ordem de grandeza a intensidade medida, melhorava a relação sinal/ruído, com a vantagem de tornar o feixe monocromático.

d) Efeito observado nos diagramas de espalhamento

Observamos nos difratogramas a baixos ângulos, que em 6.5 graus sempre surgia um pico, independente da amostra em estudo.

Após considerar como possíveis causas o espalhamento pelo porta-amostra, por alguma das peças do difratômetro e a divergência do feixe, verificamos que a forma com que foi implementado o braço de deteção permitia a passagem de uma parte do feixe direto numa certa posição relativa entre os dois braços (o da fonte e de deteção), que corresponde, na medida do goniômetro a 6.5 graus.

\section{V.3 Difratogramas}

Mostramos a seguir à título de exemplo de aplicação, quatro difratogramas obtidos com o goniômetro $\theta-\theta$

A: Silício policristalino, primeiros difratogramas. Ver condições de trabalho no difratograma.

B: Silício policristalino. Dois difratogramas superpostos. 

C: Alumínio policristalino
D: Água destilada 


\begin{tabular}{|c|c|c|c|}
\hline amostra & B & C & D \\
\cline { 1 - 2 } $\begin{array}{c}\text { fenda de } \\
\text { divergência }\end{array}$ & 0.12 & 0.12 & 0.44 \\
\cline { 1 - 1 } $\begin{array}{c}\text { fenda } \\
\text { espalhamento }\end{array}$ & 0.44 & 0.44 & NÃO \\
\cline { 1 - 1 } fenda recepção & 0.08 & 0.04 & NÃO \\
\cline { 1 - 1 } monocromador & NÃO & NÃO & SIM \\
\cline { 1 - 1 } tempo de & 3 & 3 & 100 \\
\cline { 1 - 1 } contagem & 0.02 & 0.002 & 0.5 \\
\cline { 1 - 1 } passo & $30 / 15$ & $40 / 15$ & $50 / 25$ \\
\hline
\end{tabular}

(i) A abertura das fendas é dada em milímetro, o tempo de contagem em segundos, o passo em graus e a notação da fonte obedece a forma $\mathrm{Kv} / \mathrm{mA}$.

(ii) Em todos os difratogramas foram usadas fendas soller. 


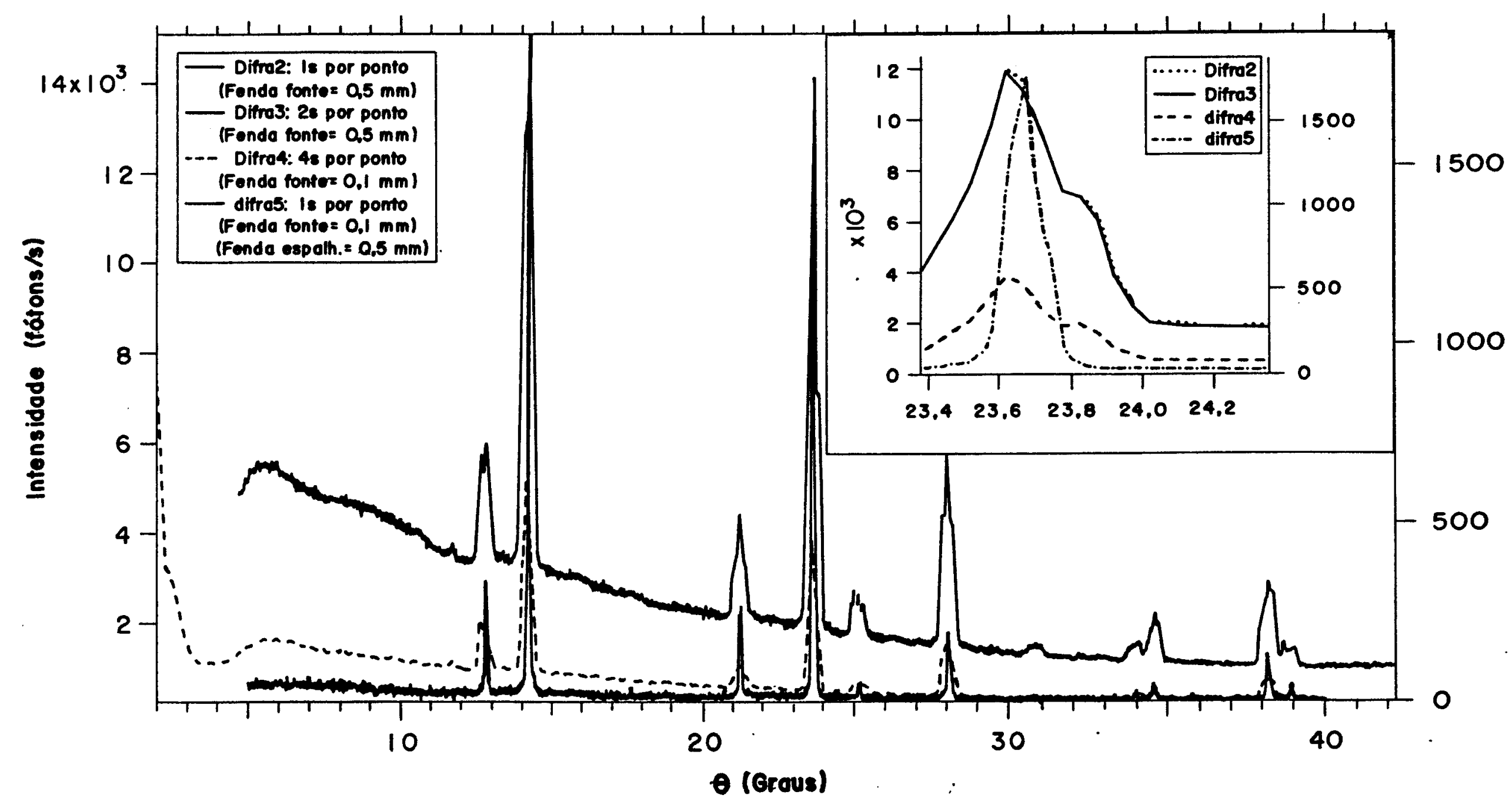


fotons/s (difrat8)

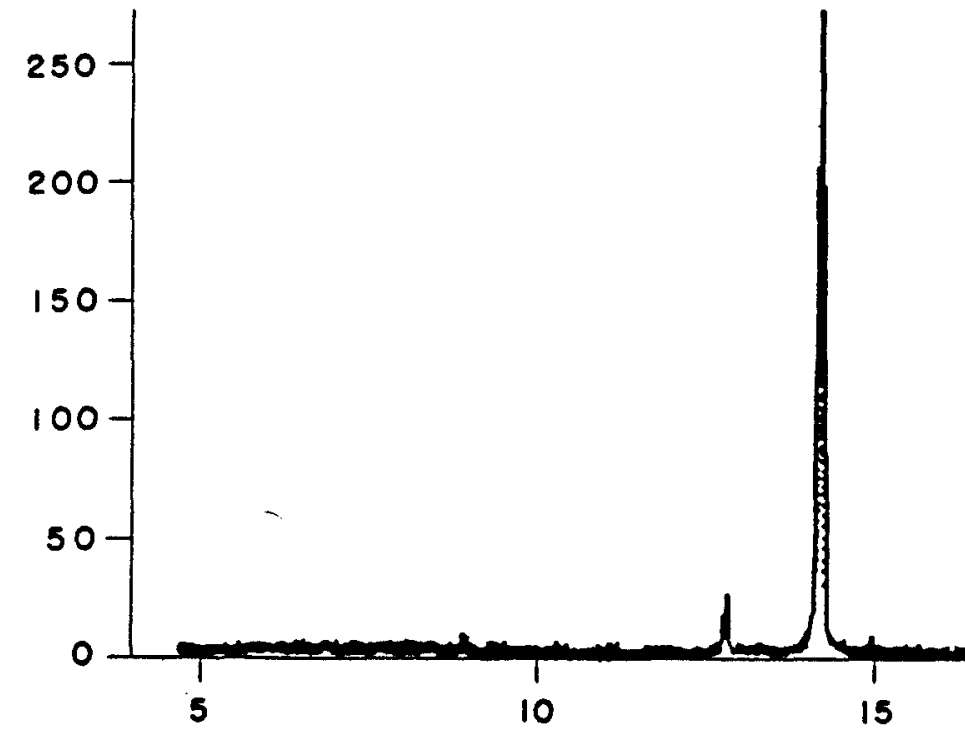

fotons/s (difrat7)

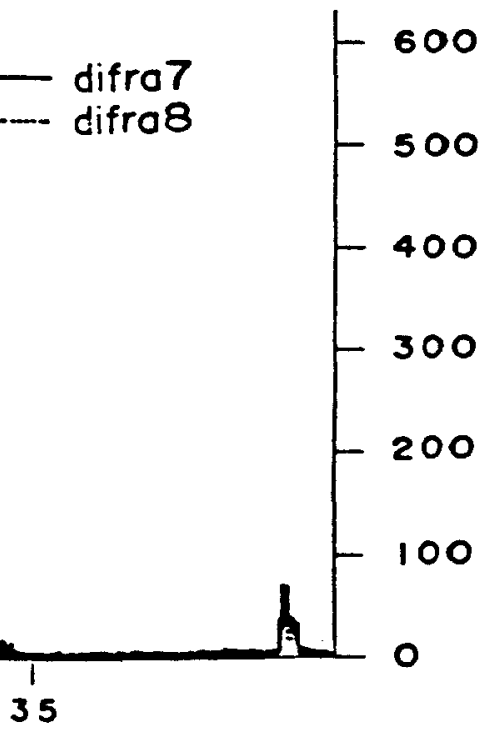

$\theta$ (Graus) 


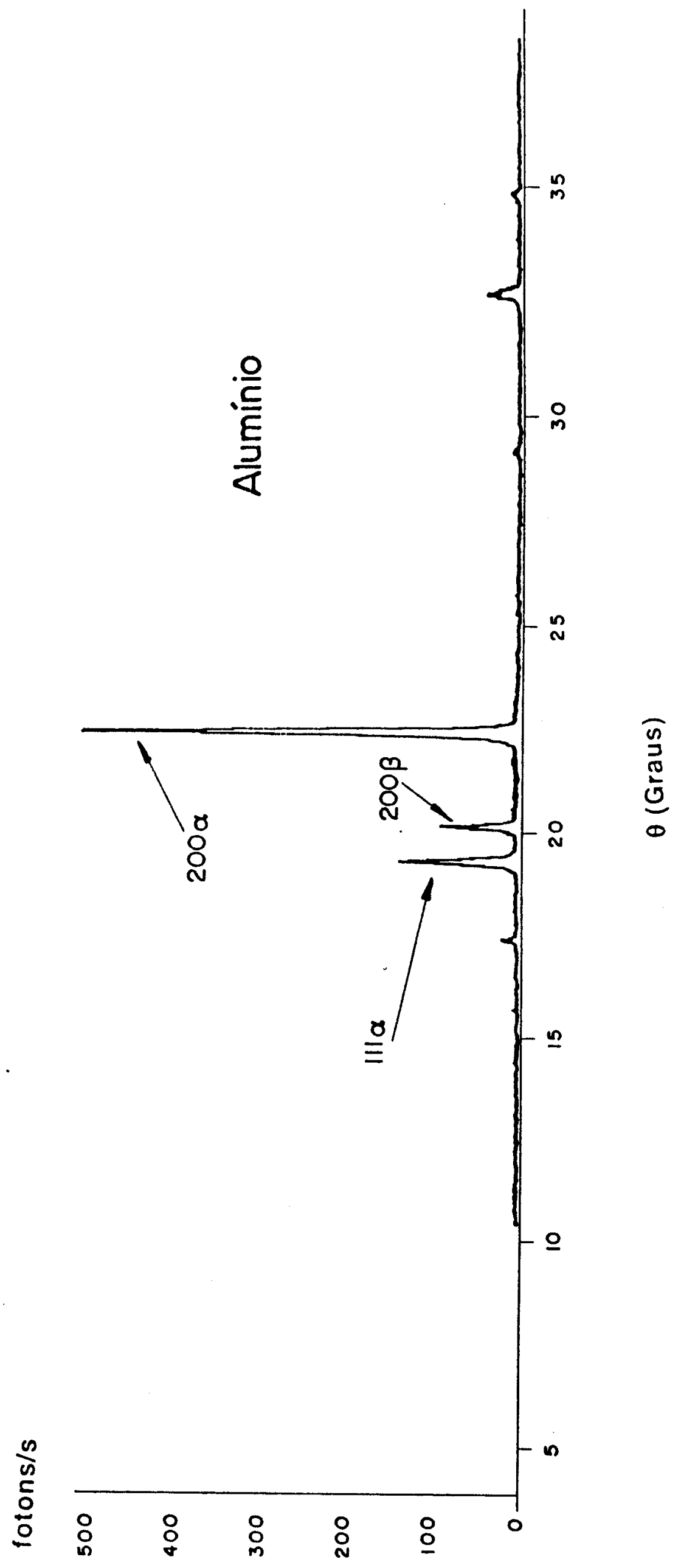




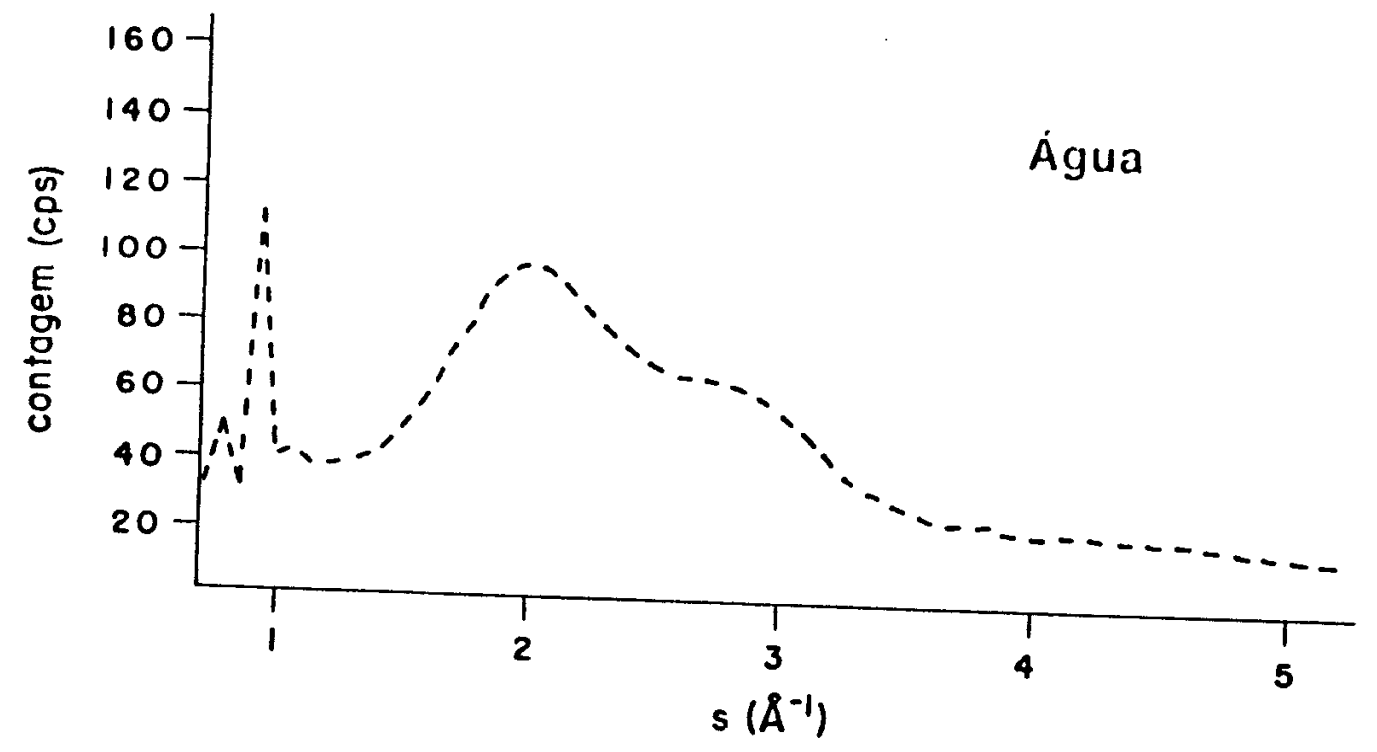

O pico que aparece próximo de $6.5^{\circ}$ é devido ao espalhamento do feixe direto por baixo do monocromador, onde não havia blindagem 


\section{Capítulo VI}

\section{Discussão e Conclusão}


Tratamos no capítulo I os dois tipos de amostras que o difratômetro pode aceitar: policristais e líquidos. Vimos também, apesar de não extensivamente, as informações que a técnica pode fornecer.

No capítulo II tratamos ainda de forma geral alguns aspectos da óptica utilizada no goniômetro.

Nos capítulos seguintes descrevemos o trabalho realizado, primeiramente descrevendo o difratômetro (capítulo III) e em seguida a forma de controla-lo (capitulo IV).

No capítulo $V$ apresentamos os testes de avaliação do equipamento

Neste último capítulo, VI, vamos fazer um balanço do trabalho realizado. Faremos uma análise dos resultados expostos no capítulo V. Em seguida situaremos este trabalho sob o aspecto científico através da revisão bibliográfica e do aspecto comercial. Após a análise deste cenário proporemos uma nova versão para o difratômetro.

\section{Vl.1 Discussão}

a) Análise dos resultados

No capítulo $V$ fizemos um tipo de medida da qual retiramos todas as informaçōes concernentes à caracterização do difratômetro: 1- calibramos a relação entre o passo do motor e a correspondente variação angular; 2- verificamos a reprodutibilidade do difratômetro pela posição dos picos; 3- verificamos a histerese pela posição dos picos quando as medidas foram feitas em ângulo ascendente e descendente, consecutivamente.

Medimos o fator de calibração por dois métodos: auto-colimação do teodolito e difratometria. Estimamos o erro na medida pelo teodolito como sendo de \pm 10 segundos de arco para o deslocamento total em cada medida dividimos pelo número de passos. Estimamos o erro na difratometria pela "estatística" das contagens

Considerando-se a espessura das fitas e tolerâncias de usinagem das peças, estimamos um fator de calibração "construtivo" que é apresentado na Tabela 6.1, junto com os valores determinados por esses dois métodos. 


\begin{tabular}{|ll|}
\hline Método & $\Delta \theta_{\min }$ (graus) \\
\hline Teodolito & $(5.02 \pm 0.02) \times 10^{-4}$ \\
Difratometria & $(4.9965 \pm 0.0005) \times 10^{-4}$ \\
\hline Construtivo & $(5.00 \pm 0.05) \times 10^{-4}$ \\
\hline
\end{tabular}

Tabela 6.1: resumo dos valores para o deslocamento angular mínimo.

O valor esperado, corrigido para a espessura das fitas é de $\Delta \theta_{\min }=$ $4.9969 \times 10^{-4}$ graus. Concui-se, assim, que esta correção deve ser levada em conta no projeto deste tipo de mecanismo.

O método difratométrico é a melhor maneira de calibração do passo do difratômetro. Usando o erro experimental ( $5 \times 10^{-8} 8$ graus/passo), e supondo que ele ocorre sempre na mesma direção são necessários 100.000 passos, o equivalente a $50^{\circ}$, para que o difratograma apresente um deslocamento nos picos de $0.005^{\circ}$.

A histerese medida para os picos $333 \alpha_{1}, 333 \alpha_{2}$ e $111 \alpha$ apresentou uma média de (1.8 \pm 0.3$) \times 10^{-2}$ graus, o que exigira do software de controle uma correção automática sempre que o difratômetro mudar seu sentido de giro.

Concluímos com isto que o difratômetro deve possuir mecanismos de avaliação da diferença acumulada entre a posição corrente calculada pelo software (de movimentação do motor) e a posição real.

Entendemos que o valor de 3.4 passos $\left(0.0017^{\circ}\right)$ para a reprodutibilidade, considerando os dados relativos aos picos $333 \alpha_{1}$ e $333 \alpha_{2}$, é o que melhor descreve o funcionamento do sistema. A assimetria na reprodutibilidade em relação à "ida" e à "volta" não é conclusiva com os dados que dispomos.

b) Cenários

Do ponto de vista instrumental este trabalho tem o mérito de introduzir e testar um mecanismo simples, de fácil construção e de baixo custo. Aplicando-o a um sistema concêntrico $\theta$ sincrônico, como é o caso do difratômetro $\theta-\theta$, sugerimos uma simplificação radical neste tipo de equipamento, o que vem de encontro à necessidade generalizada de se reduzir custos sem perder eficiência. 
Por outro lado, aspectos relativos à engenharia de produto precisariam ser trabalhados para facilitar sua operação.

Através de pesquisa bibliográfica constatamos que praticamente não existem publicações sobre mecanismos para difração $\theta-\theta$., excessão feita a Kaplow [Kaplow, 1963]. Encontramos um pouco mais de material, [WEISS, 1986], [BAUN, 1963], [NORTH, 1969], [BURATINI, 1992], quando somos menos estritos, recuperando referências sobre instrumentação para laboratórios Síncrotrons, para análise de superfície, etc.

\section{c) Proposta para nova versão}

Baseado em tudo que foi dito e estudado, encontramos alguns aspectos que poderiam ser melhorados na próxima versão do difratômetro, a saber: robustez, melhor aproveitamento das dimensões do goniômetro, aumento do curso angular $e$ melhoramento do mecanismo de alinhamento do tubo.

Consideramos que a robustez do equipamento deve ser aumentada no dimensionamento adequado de suas peças, visando com isto reduzir o peso, 0 custo e aumentar sua vida útil. Isto implica também na escolha adequada dos metais empregados, preferindo-se aço inox e alumínio. Neste sentido sugerimos também que a alavanca do contrapeso poderia ser reduzida à metade.

Quanto ao aproveitamento das dimensões, constatamos que os mecanismos da parte de trás, principal responsável pela altura do goniômetro, poderiam ser compactados. Diminuindo-se o comprimento do carro e eliminando os espaços vazios entre o fuso e o eixo do motor e entre o curso do carro e os discos traseiros, podemos reduzir a altura do goniômetro em cerca de $5 \mathrm{~cm}$. Propomos ainda uma mudança na posição do motor, colocando-o na frente, na espinha do goniômetro, com seu eixo voltado para baixo. O movimento seria transmitido ao fuso por uma correia dentada. Isto eliminaria o espaço atualmente ocupado pelo motor mas exigiria uma nova avaliação da histerese.

Os mecanismos para alinhamento do tubo empregaram um mancal cônico (que permite o feixe passar pelo centro do difratômetro) e um parafuso com porca (que permite o paralelismo da superfície do feixe com a amostra) entre a peça de sustentação do tubo e o braço.

O mancal cônico funcionou bastante bem, apesar de não oferecer um deslizamento suave, útil principalmente quando se deseja um ajuste fino. $O$ sistema 
com parafuso para horizontalização do foco do tubo simula razoavelmente bem uma rotação em torno do caminho óptico.

Além destas melhorias em relação ao que já foi feito, podemos ainda assinalar algumas adiçōes que certamente devem fazer parte de trabalhos futuros. Podemos resumi-las em três itens: (1) a substituição do sistema de controle por outro que permita um controle mais estrito da posição do difratômetro. (2) implementação de um porta-amostra mais tácil de manipular; (3) colocação de blindagem ao longo do caminho óptico para oferecer mais segurança ao usuário.

O sistema de controle que utilizamos, o SCOPE, foi especialmente desenvolvido para atender às necessidades de um laboratório. Sua versatilidade e simplicidade foi de grande ajuda na execução dos experimentos. Numa próxima fase, porém, sugerimos que esta parte do difratômetro seja trabalhada no sentido de torna-la mais específica ao trabalho em questão.

Sugerimos que seja implementada uma régua digital ao longo do curso do carro para checar a posição do difratômetro.

O porta-amostra.para este tipo de goniômetro deve permitir um ajuste vertical (para alinhar a superfície da amostra com o centro do difratômetro). Além disto ela deve ser fechada para evitar a evaporação do soluto, no caso de amostras líquidas.

Propomos na Figura 6.1 um porta-amostra composto de um cilindo externo fixo no goniômetro. Seu interior contém uma gaveta com duas depressões. Em uma é colocada uma cubeta com a amostra, a outra pode ser usada quando se trabalha com amostras líquidas e se deseja manter a atmosfera saturada com o solvente.

O nivelamento é feito com um pequeno movimento de rotação da gaveta dentro do cilindro, com $O$ auxílio de um vernier. $O$ ajuste vertical é feito movimentando-se o porta-amostra ao longo de dois eixos. 


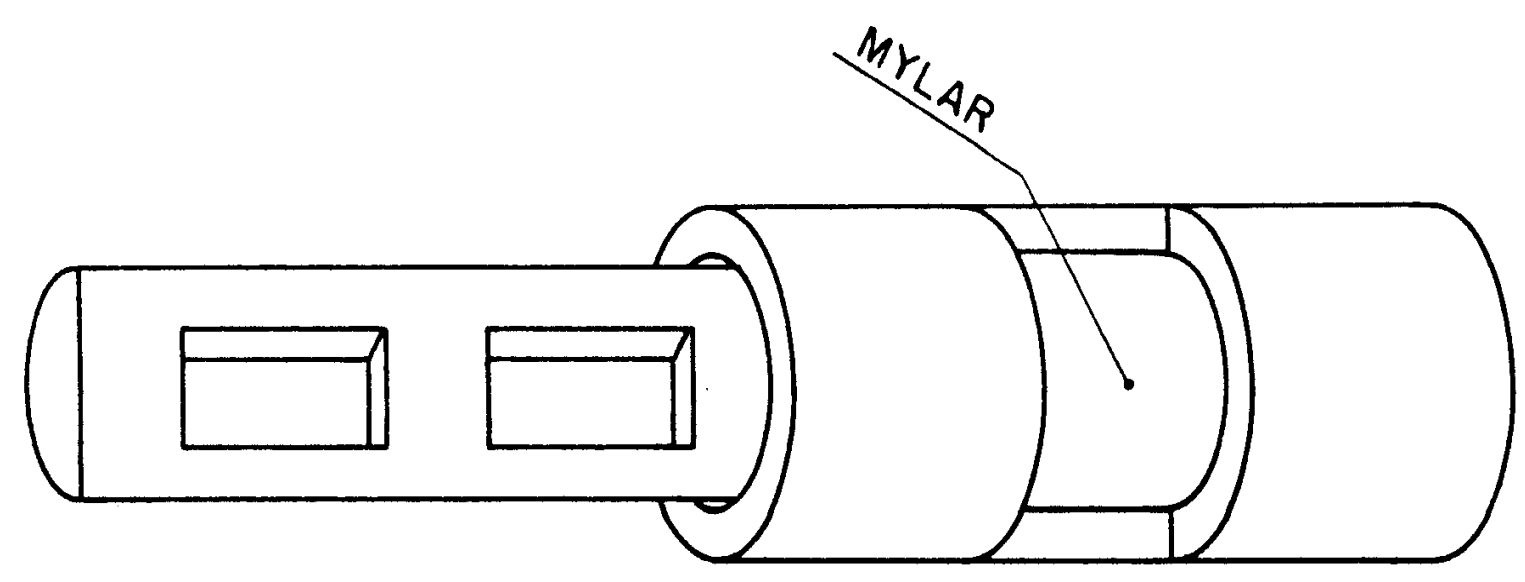

Figura 6.1: porta-amostra proposto. Não mostramos os eixos para ajuste vertical

\section{VI.2 Conclusão}

Finalmente podemos concluir que o objetivo do trabalho foi alcançado: a construção de um goniômetro $\theta-\theta$ utilizando um novo mecanismo de acionamento por fitas metálicas, com desempenho semelhante aos instrumentos deste tipo oferecidos comercialmente.

Os testes mostram um desempenho mais que adequado ao estudo de amostras em pó ou líquidas, quanto à reprodutibilidade de posicionamento $\left(0.0017^{\circ}\right.$ ) e histerese $\left(0.02^{\circ}\right)$. 
AZAROFF, L. V., BUERGER, M. J. The Powder Method, McGraw-Hill, 1958.

BAUN, W.L., RENTON, J., J., A true focusing attachment for the X-Ray diffractometer, J. Sc. Instrum., v.40, p.498-499, 1963.

BRAGG,L., CLARINGBULL,G.F., TAYLOR,W.H., Crystal Structures of Minerals, Cornell University Press, New York, 1956

BUERGER, M. J. X-Ray Crystallography, John Wiley \& Sons, New York, 1949

BURATTINI, E., SIMEONI, S., Cappuccio, G., Maistrelli, P., The high-resolution powder diffraction station PO DI STA is "running" at Adone, Rev. Sc. Instrum, v.63, n.1, p.1002-1005, 1992.

BURNS, G.D., Space Groups for Solid State Scientists, Academic Press. Inc., 1978.

CROMER, D. T., MANN, J. B., Compton scattering factors for spherically symmetric free atoms, J. Chem. Phys, v.47,n.6, p.1892-1893, 1967.

CROMER, D. T., MANN, J. B., X-ray scattering factors computed from numerical Hartree-Fock wave functions, Acta Cryst., v.A24, p.321-324, 1968.

CROMER, D. T., Anomalous dispersion corrections computed from self-consistent field relativistic Dirac-Slater wave functions, Acta Cryst., v.18, p.17-23, 1965.

DEBYE, P., Ann. Physik, v.46, p.809-, 1915.

ERGUN, S., BRAUN, W., FITZER, E., Elimination of the Compton component of diffusely scattering substances, Rev. Sc. Instrum, v.41, p.1133-1135, 1970.

HAJDU, F., PÁLINKÁS, G., On the determination of the absolute intensity of $X$-rays scattered by a non-crystalline specimen, J. Appl. Cryst., v.5, p.395-401, 1972.

HERMS, G., HAJDU, F., Non-focusing diffractometer for X-ray studies on weakly absorbing amorphous materials, J. Appl. Cryst., v.17, p.140-146, 1984.

HARSHAW Scintilation phosphors Calalog, $3^{a}$ ed., 1978

INTERFACE Inteligente, Manual do Usuário, 1989

JOHANSSON, G., X-ray diffraction investigation of solutions, Acta Chemica Scandinavica, v.43, p.307-321, 1989.

KAPLOW, R., AVERBACH, B. L. X-Ray diffractometer for the study of liquid strutures, Rev. Sc. Instrum., v. 34, n.5, p.579-581, 1963.

KLUG, H. P., ALEXANDER, L. E. X-Ray Diffraction Procedures for Polycrystalline and Amorphous Materials, John-Wiley \& Sons, New York, 1974. 
KURAHASHI, M., HONDA, K., GOTO, M., J. Appl. Cryst. v.24, p.61-63, 1991.

LEVY, H. A., AGRON, P. A. ; DANFORD, M. D. X-Ray diffractometry with slightly absorbing samples, v. , n. , p. 2012-2013, 1959.

MATSUSHITA, T., HASHIZUME, H., X-Ray Monocromator, Handbook on Synchrotron Radiation, v.1, cap.4, E. E. Koch, 1983

MILBERG, M. E., Transparency Factor for Weakly Absorbing Aamples in X-Ray Diffractometry, J. Appl. Phys., v.29, p.64-65, 1958.

NARTEN, A. H., SANDLER, S. I., X-ray Diffraction Study of Liquid Tertiary Butyl Alcohol at $26^{\circ} \mathrm{C}$, J. Chem. Phys., v.71, n.5, p.2069-2073, 1979.

NORTH, D. M., WAGNER, C. N. J., An X-Ray transmission diffractometer with a high temperature camera for the study of liquids, J. Appl. Cryst., v.2, p.149-155, 1969.

PARRISH, W., ROBERTS, B. W., Filter and Crystal Monochromator Techniques, in:XRay Analisys Papers. p.31-46, Centrex Pub. Co., 1965

PETKOV, V., RAD, a program for analysis of $X$-ray diffracton data from amorphous. material for personal computers., J. Appl. Cryst., v.22, p.387-389, 1989.

PINGS, C. J., WASER, J., Analysis of scattering data for mixtures of amorphous solids or liquids, J. Chem. Phys., v.48, p.3016-3018, 1968.

RODRIGUES, A. R.D., TAVARES, F. da SILVA, C. R. SCORZATO, CUSATIS, C. MAZZARO, I., SCOPE: A versatile system for data collection and control of experiments, - Rev. de Fis. Apl. e Instrum. v. 6, n.2, p.63-72, 1991.

STOUT, G. H., JENSEN, L. H., X-Ray Structure Determination, John Wiley \& Sons, 1989

WARREN, B. E., X-ray determination of the structure of liquids and glass, J. Appl. Phys., v.8, p.645-654, 1937.

WARREN, B. E., MOZZI, B. L., Multiple scattering of X-rays by amorphous samples, Acta Cryst, v.21, p.459-461, 1966.

WARREN, B. E., MOZZI, R .L., Corrections for intensity measurements from glass samples, J. Appl. Cryst., v.3, p.59-65, 1970.

WEISS, A. H., DEUTSCH, M., BRASLAU, A., OCKO, B. M., PERShaN, P. S. - Rev. Sci. Instrum, v.57, n.10, p.2554-2559, 1986.

ZERNICKE, F., PRINZ, J. A., Zeit. Physik, v.41, p.184-, 1927. 


\section{Apêndice I}

\section{Listagem do Programas}


1* Versao DIFRAT41.C: arquivo de dados e aberto e fechado 1 vez */

1*

DIFRAT.C version serie 4

1* This program guides the scope system to move the motor and read the $*$ $1 *$ counter to obtain a diffratogram

*I

* List of Variables:

* stan start angle

* ston stop angle

* span step angle

$f *$ coti counting time

* nansp number of angular steps

1* mosas motor steps per angular steps

* tmpf temporary file

$*$ tmpr "variable

1* mess message from scope

1* moto[ command motor string

I* cote[ command counter string
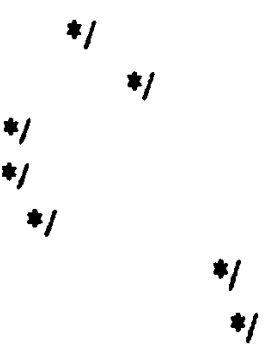

*1

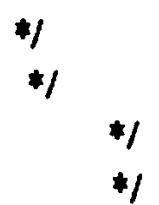

/ Sintax motor and counter commands:

$*$

* command:MOTOR,address, velocity,rotation direction,number of steps */

/* command:CONTADOR, address, counting time

* Serial port format communication, prgrs():

** linectrl $=128\left(\begin{array}{lllllllll}1 & 0 & 0 & 0 & 0 & 0 & 0 & 0\end{array}\right)$ permit to access boud rate generator */

$/ * \mathrm{msb}=0, \mathrm{lsb}=12$ set 9600 bouds

/ linectrl $=3(0000000011)$

/* bit bit 0 *1

/* $011 \times$ (even/odd parity)

* 118 bits word length $5 X$ (stick parity)

/* 201 stop bit 60 disable set break

/* 30 no parity bit 70 disable boud rate genrator access *

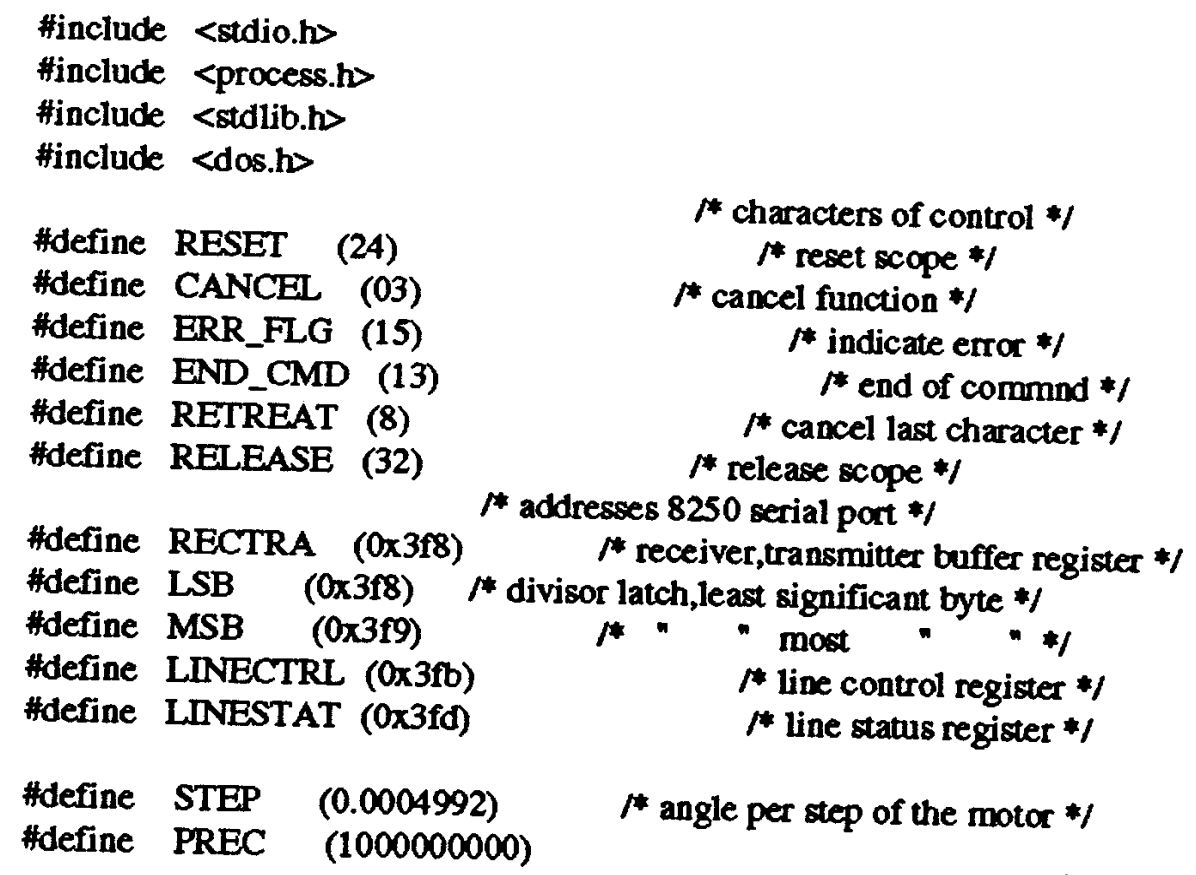




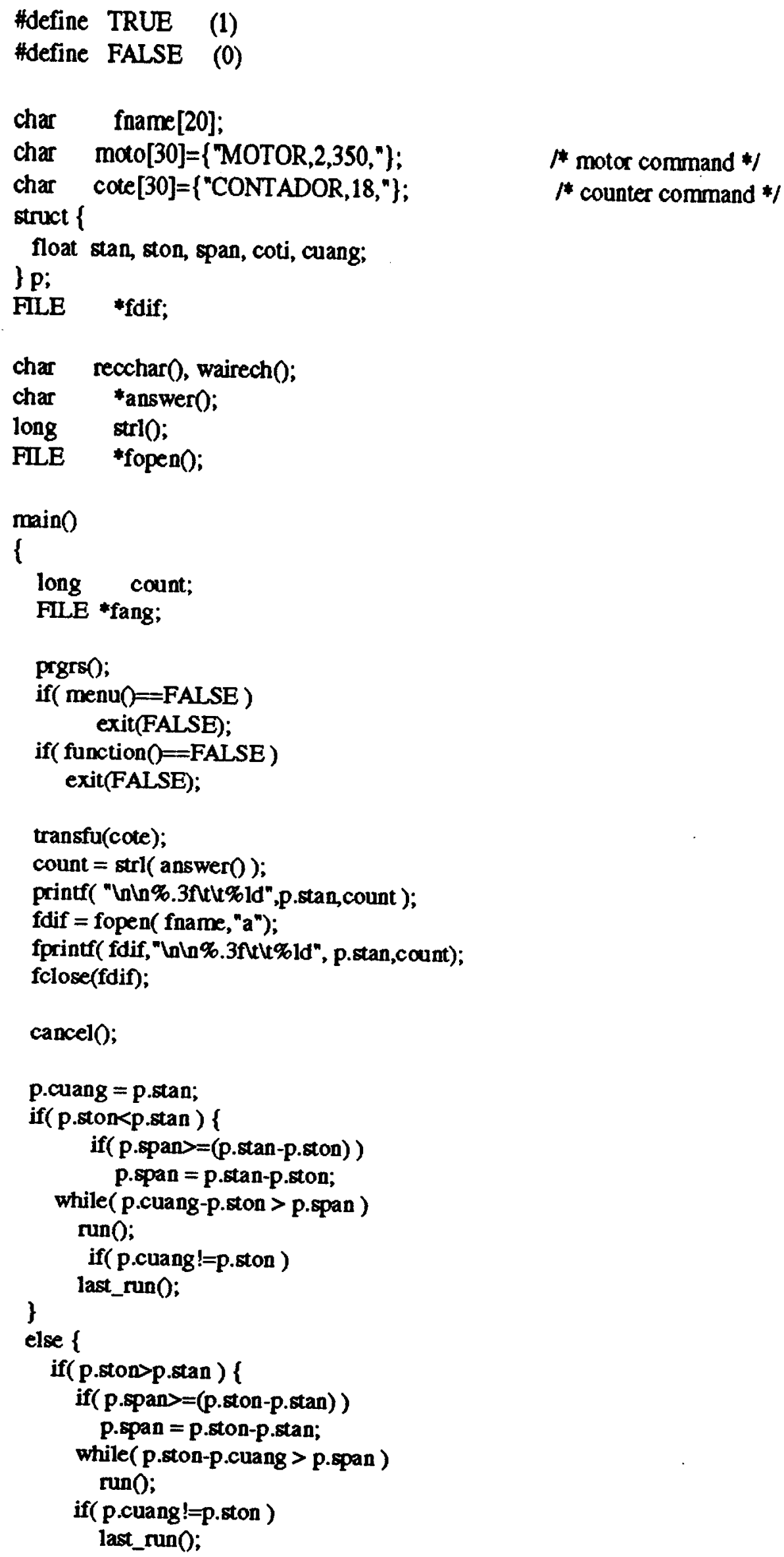




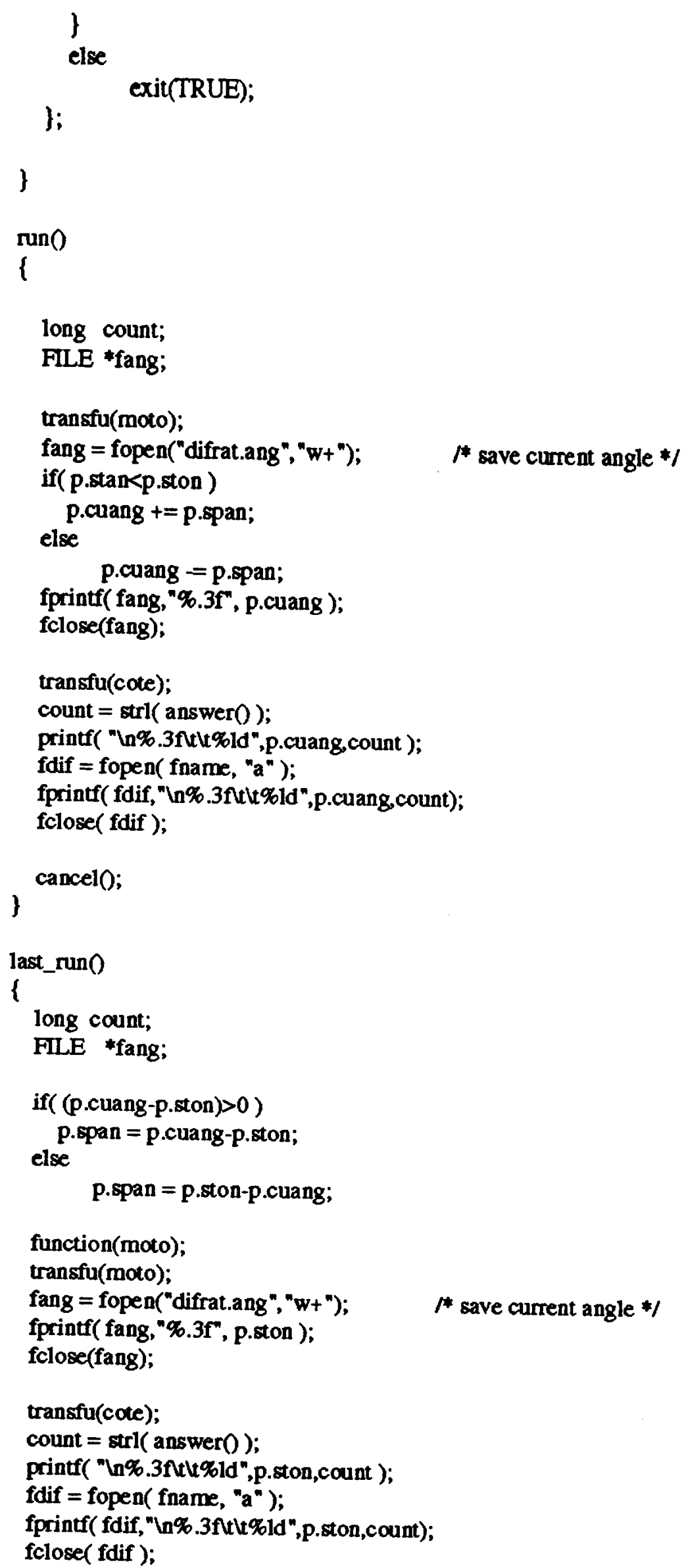




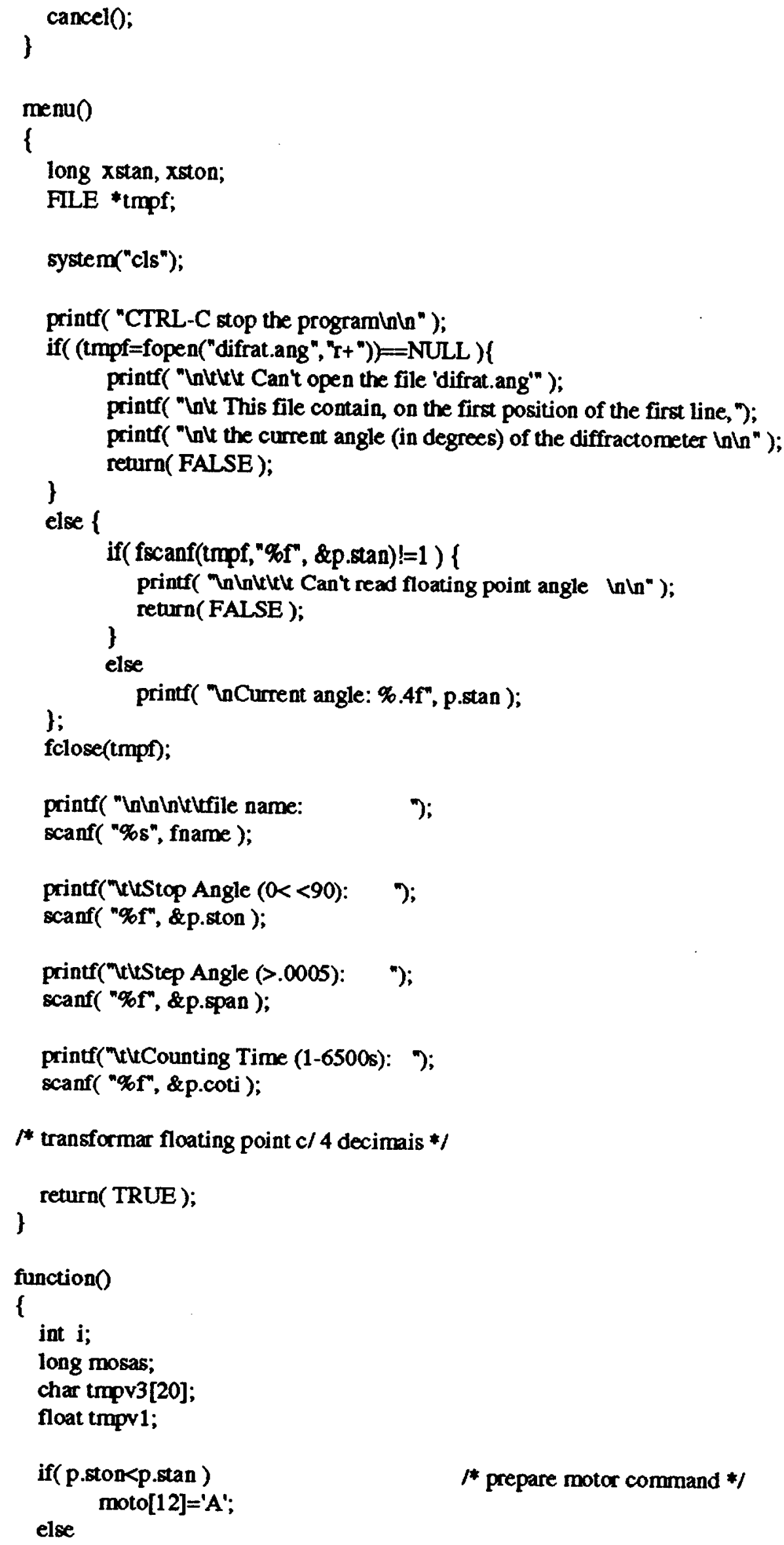




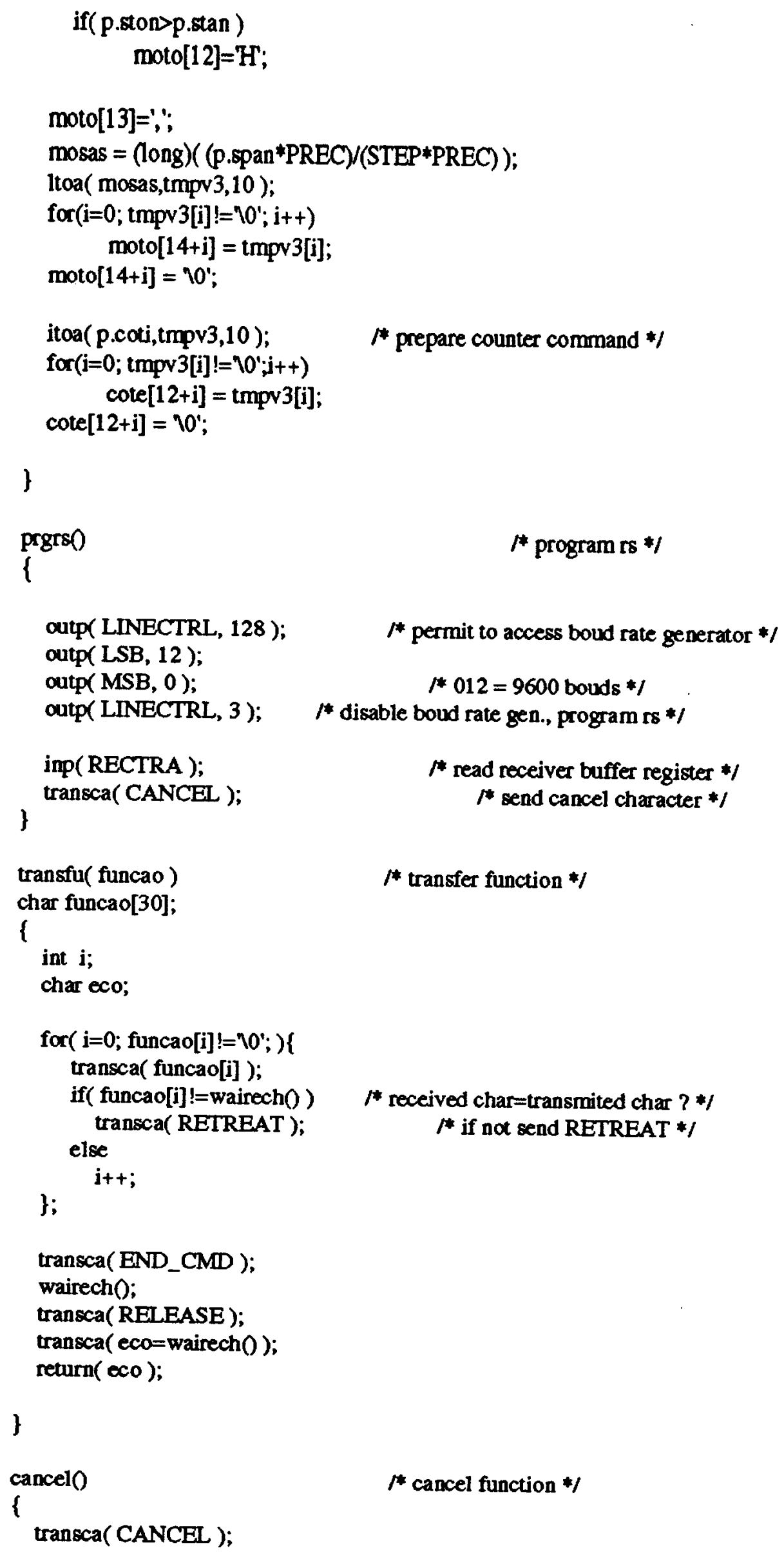




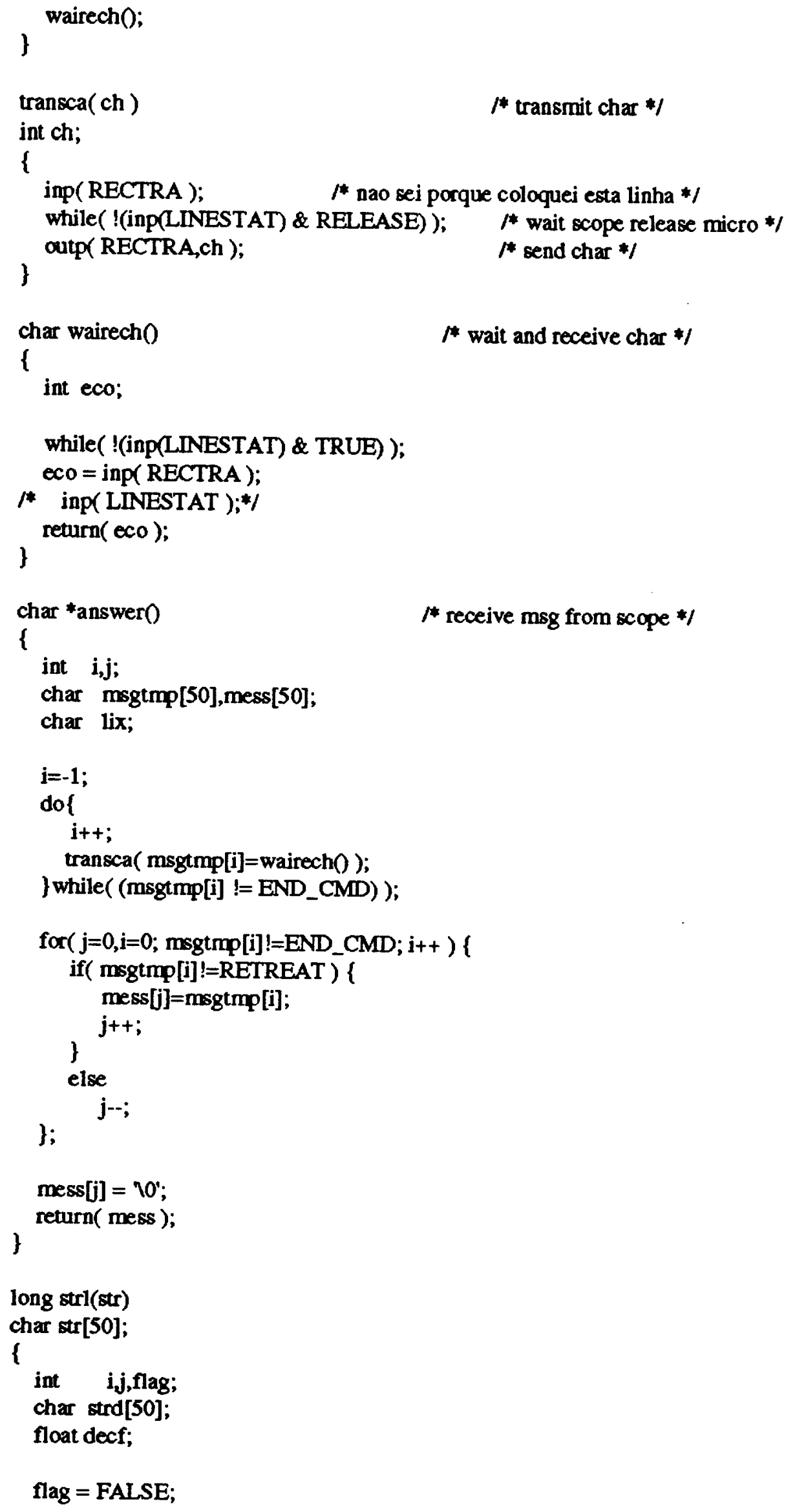




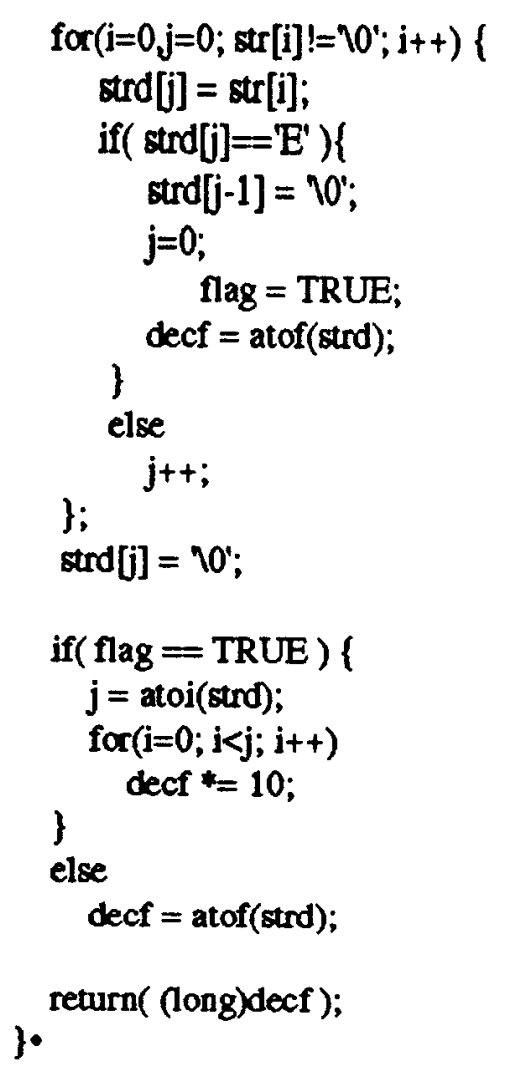




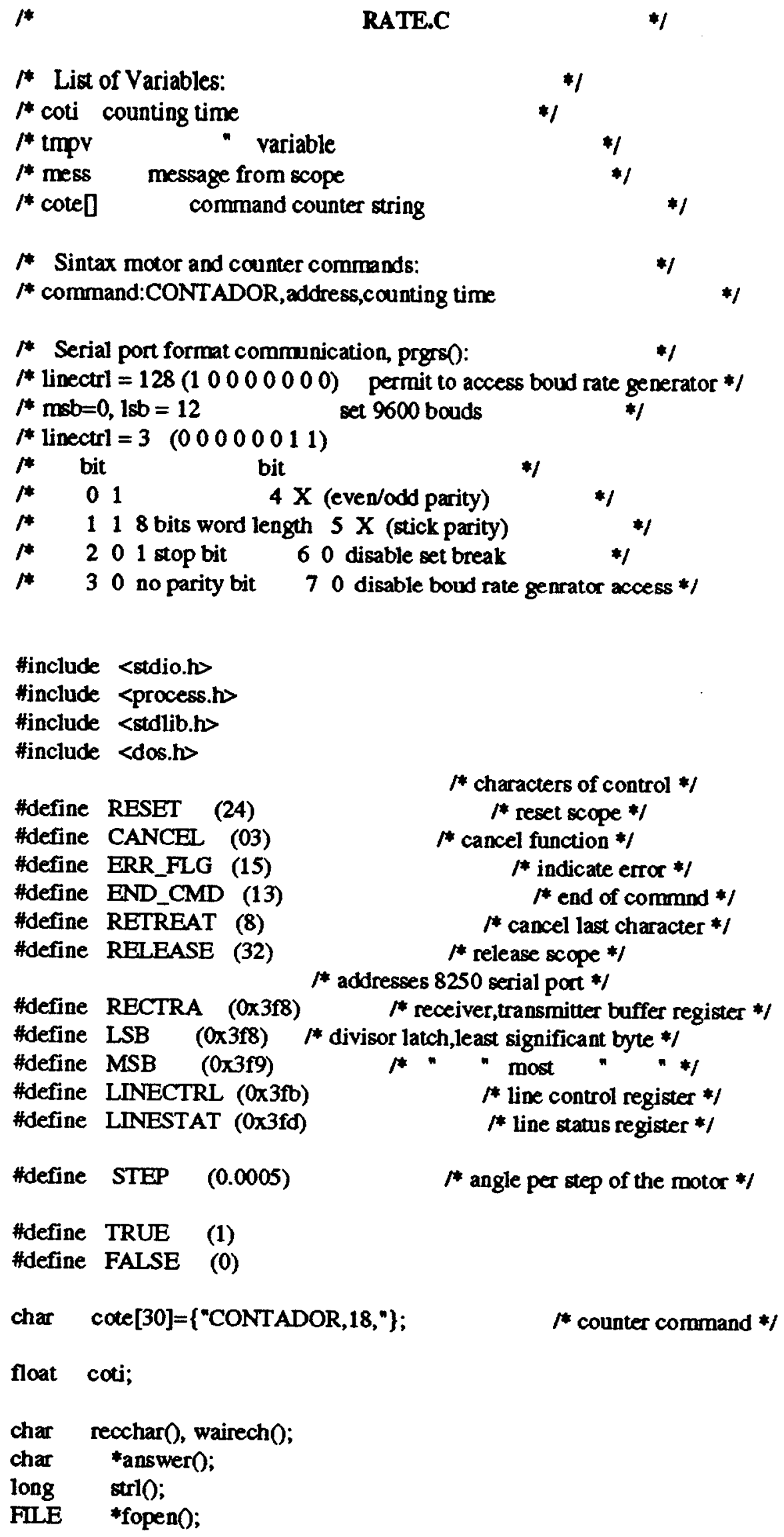

1* List of Variables:

$\rho^{*}$ coti counting time

t* tmpr

- variable

1* mess

message from scope

$1 *$ cote[

command counter string

$* 1$

$* 1$

$* 1$

$*$

/* Sintax motor and counter commands:

$*$

* command:CONTADOR, address,counting time

* Serial port format communication, prges (0:

4

$/ *$ linectrl $=128(100000000)$ permit to access boud rate generator */

$\mu * \mathrm{msb}=0,1 \mathrm{sb}=12$ set 9600 bouds

*1

$/ *$ linectrl $=3(0000000011)$

1* bit bit

1* 01

/* 118 bits word length $5 \mathrm{X}$ (stick parity)

$\rho^{*} \quad 201$ stop bit 60 disable set break

/* 30 no parity bit 70 disable boud rate genrator access *1 


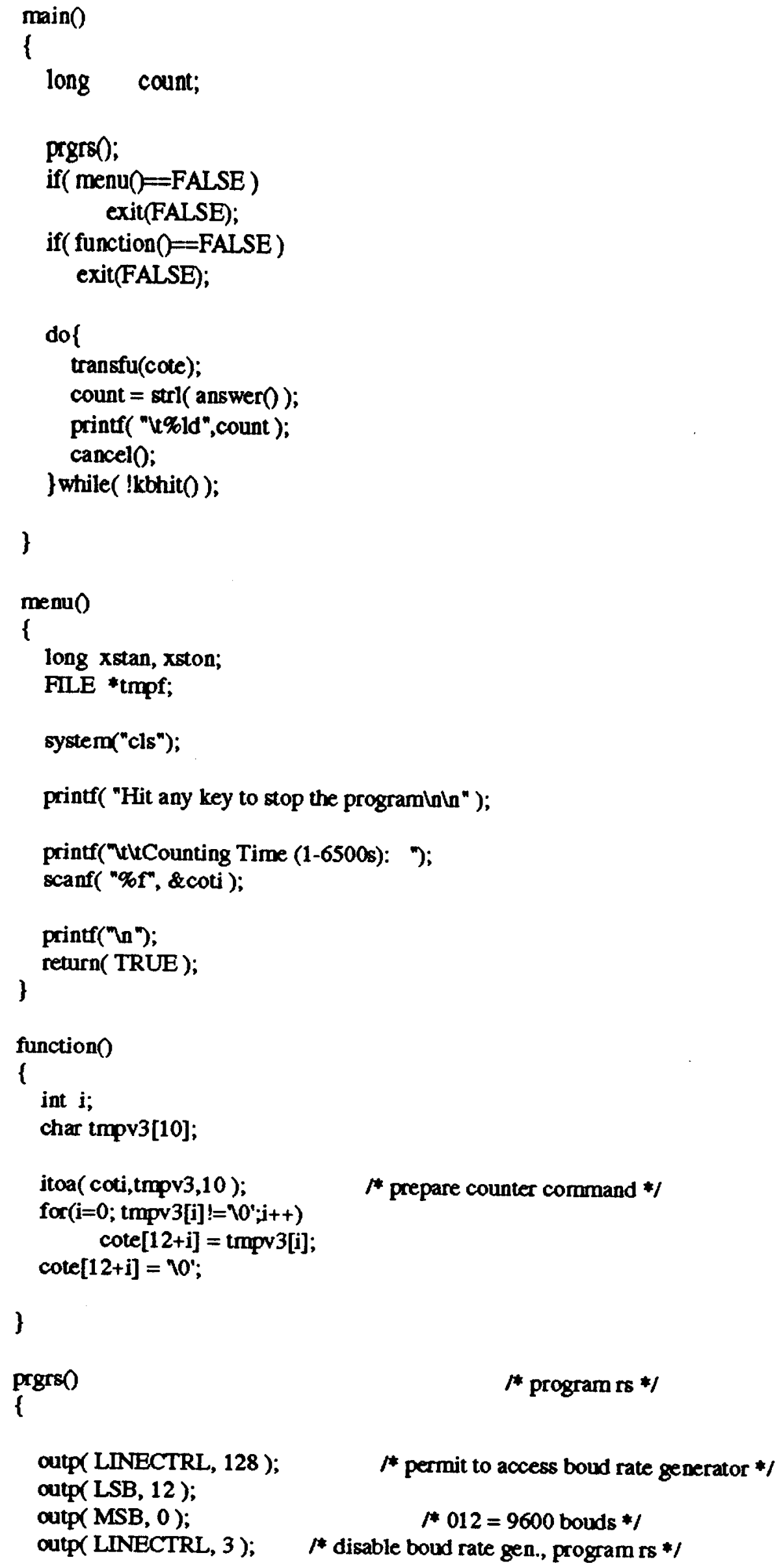




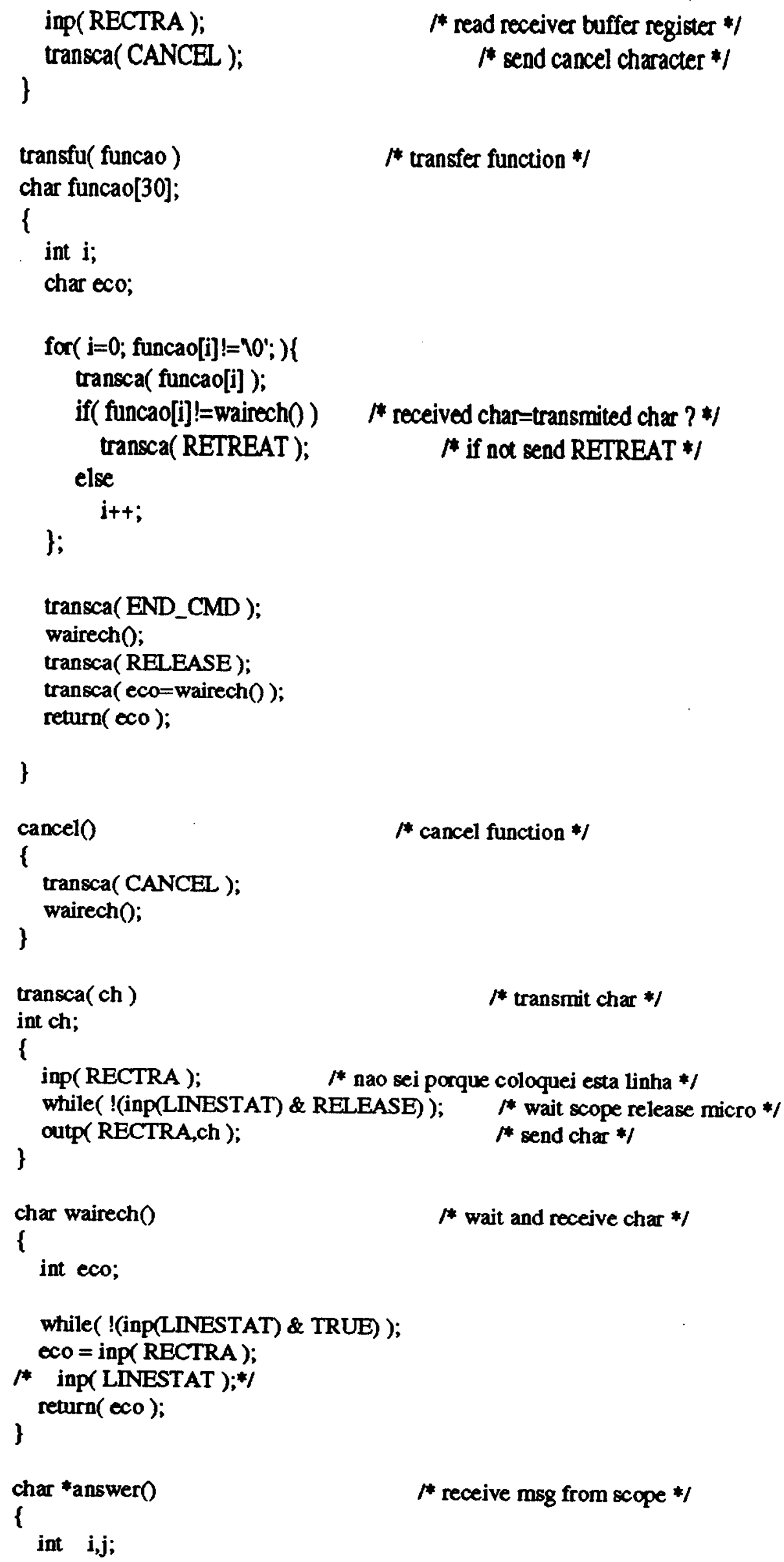




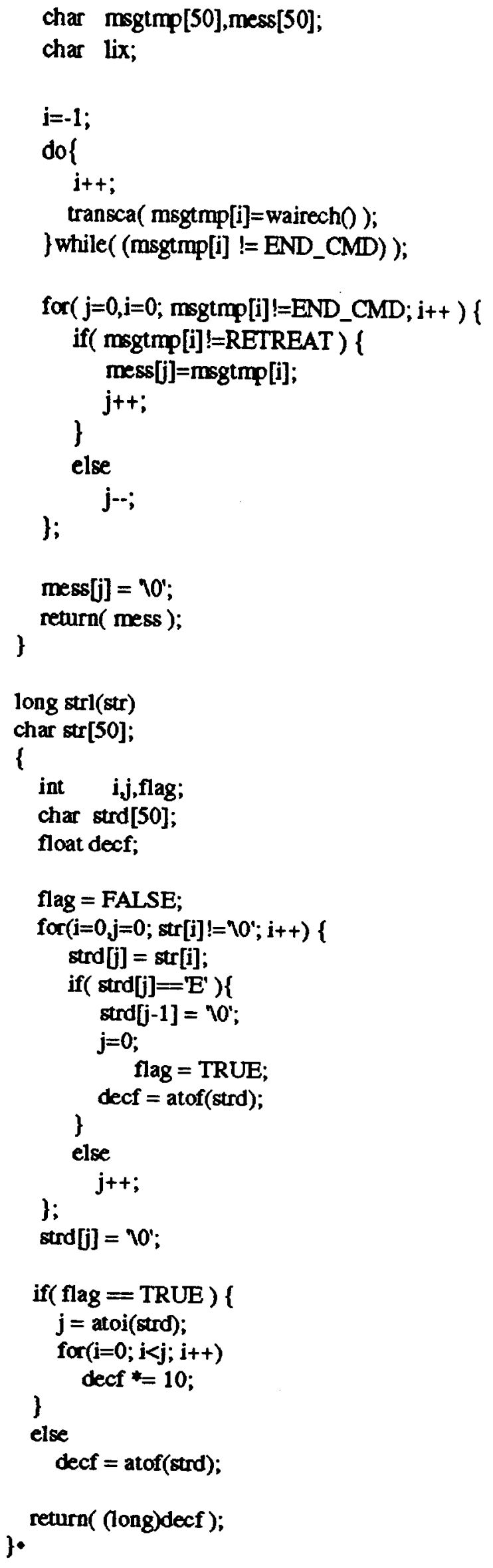


Apêndice II

Desenho do Difratômetro

(vista dos braços) 


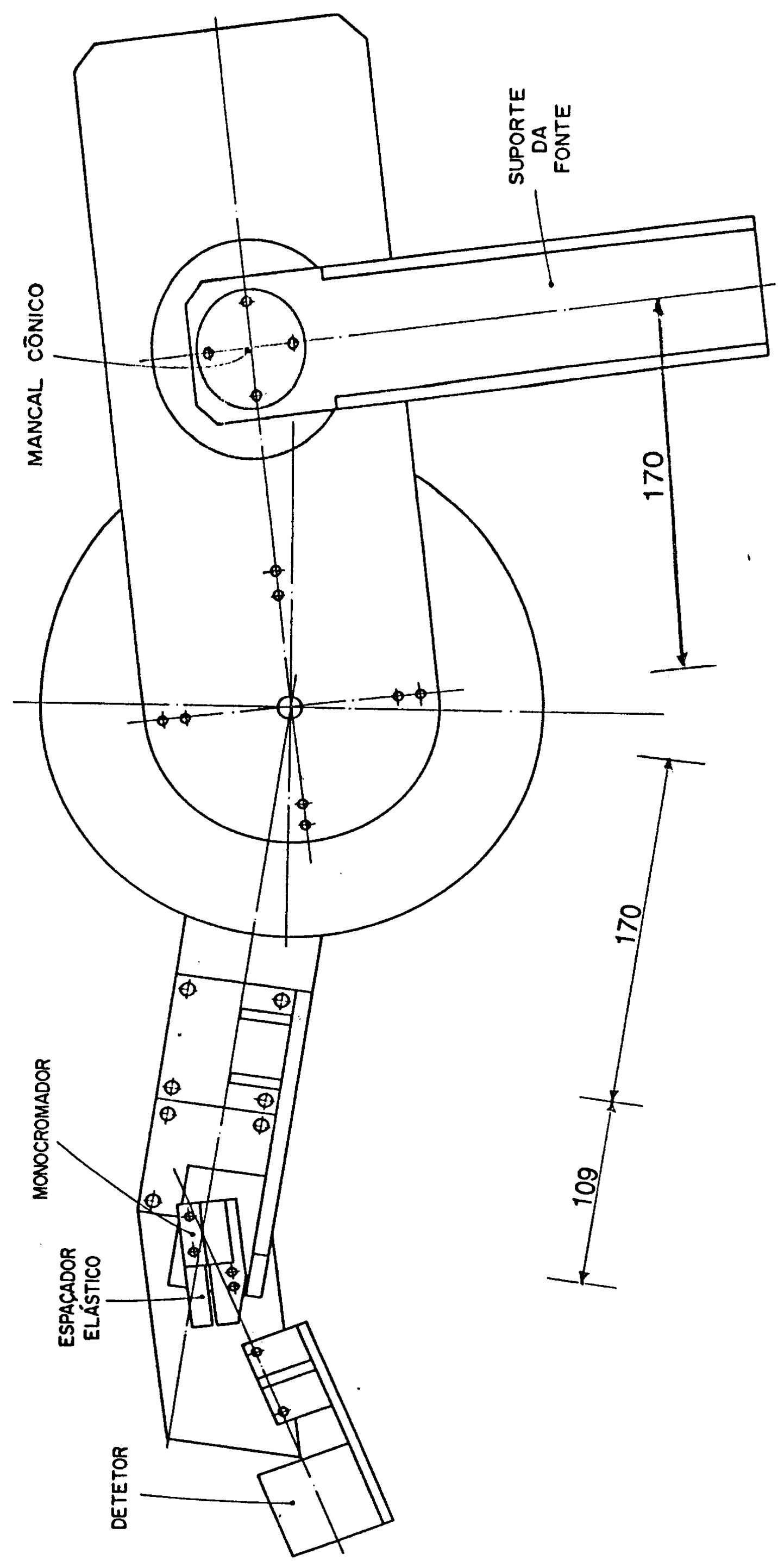


Apêndice III

Fotos do Difratômetro 


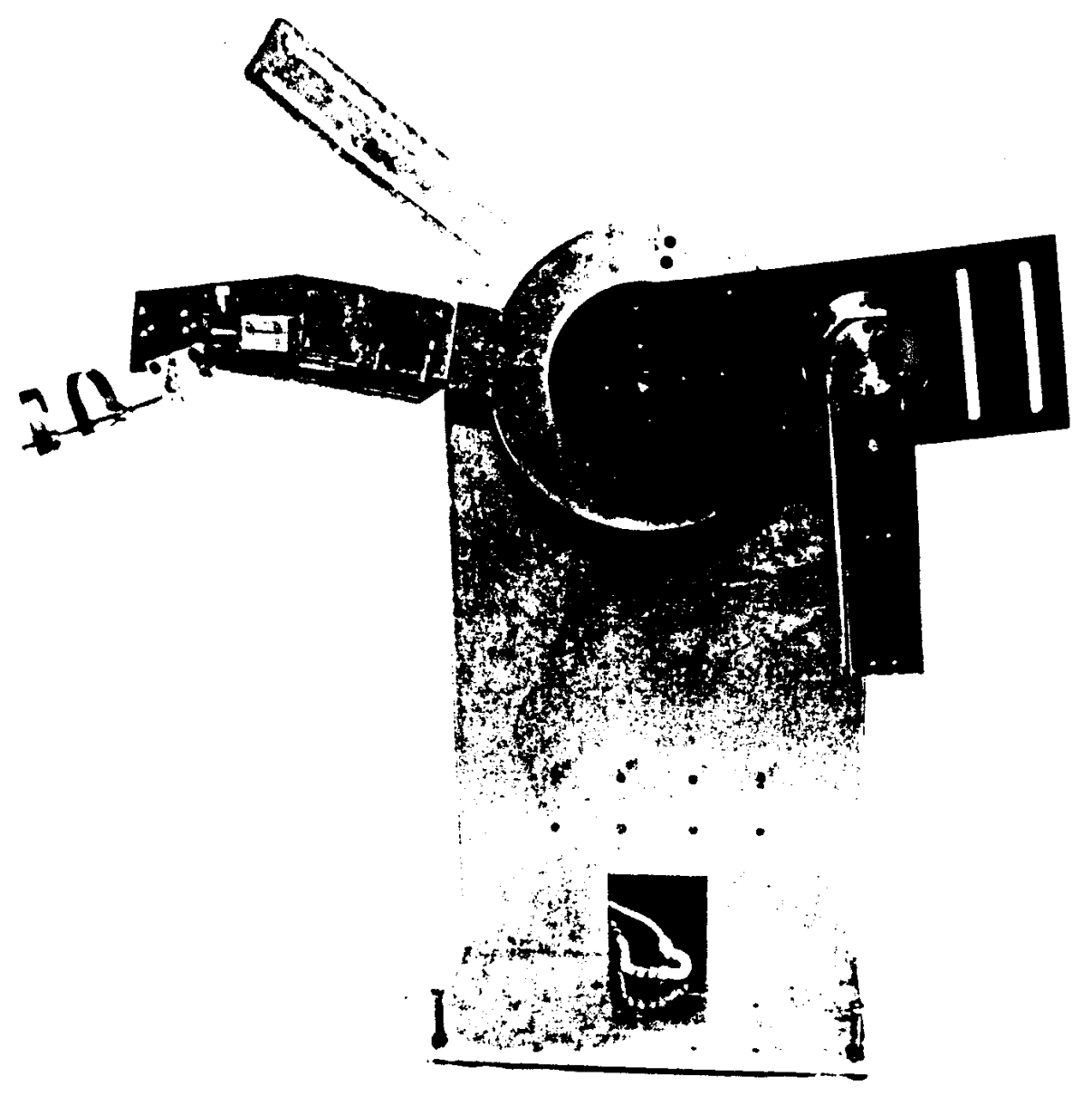




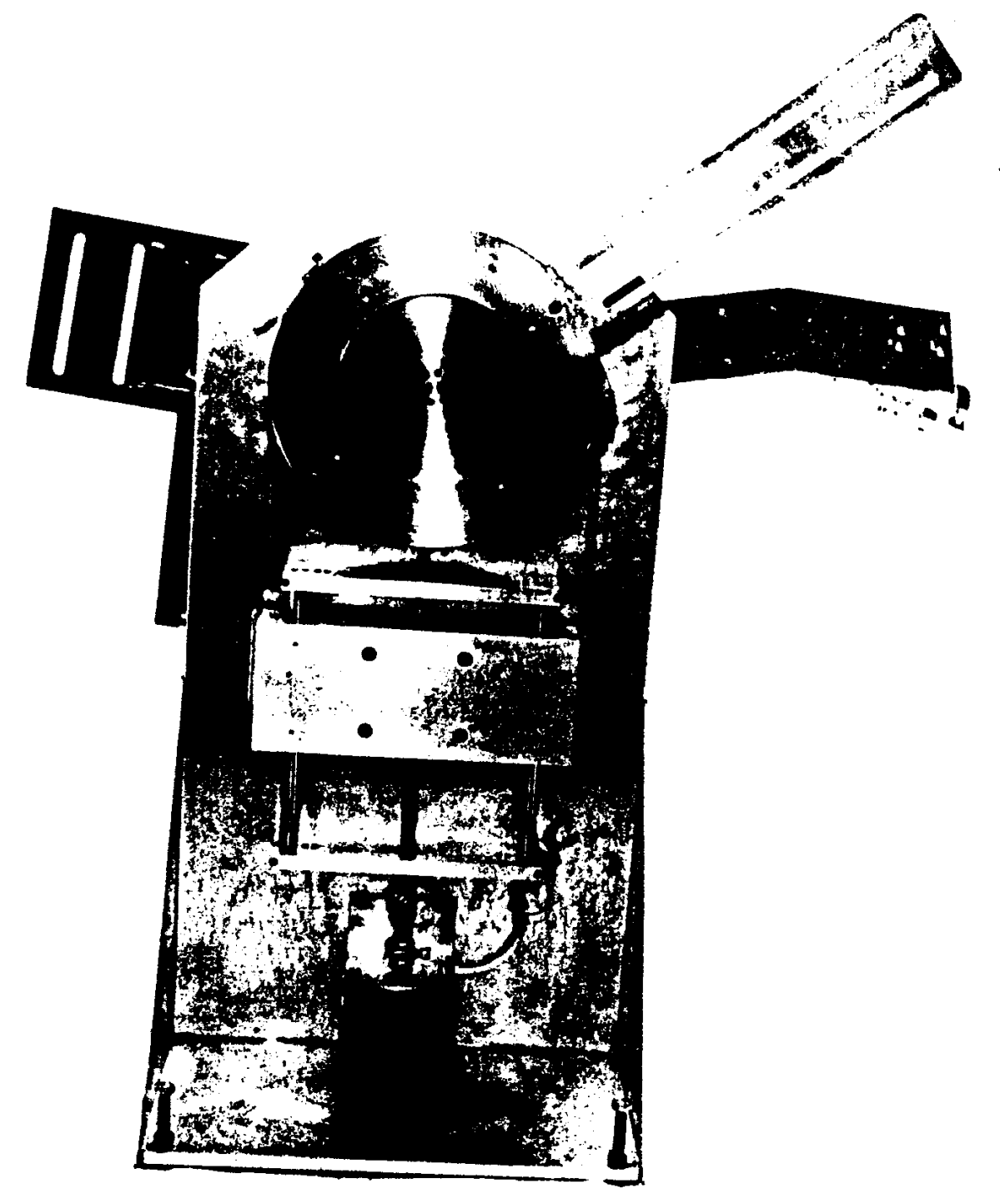

